\title{
THE PROPERTIES OF CYCLES IN SOUTH AFRICAN FINANCIAL VARIABLES \\ AND THEIR RELATION TO \\ THE BUSINESS CYCLE
}

Willem Hendrik Boshoff

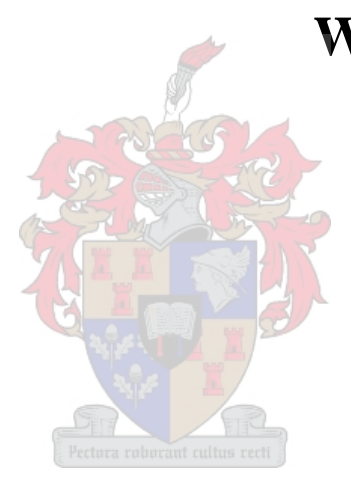

Thesis presented in partial fulfilment of the requirements for the degree of Master of Commerce (Economics) at Stellenbosch University

Supervisor: Professor S.A. du Plessis

April 2006 
Declaration

I, the undersigned, hereby declare that the work contained in this thesis is my own original work and that I have not previously in its entirety or in part submitted it at any university for a degree.

Signature

Date 


\section{ABSTRACT}

The goal of this thesis is twofold: it aims, firstly, at a description of cycles in South African financial variables and, secondly, at the evaluation of the relationship between cycles in financial variables and the South African business cycle. The study is based on the original business cycle framework of Arthur Burns and Wesley Mitchell, but incorporates recent contributions by Australian economists Don Harding and Adrian Pagan, as well as the work of the Economic Cycle Research Institute in New York.

Part I of the thesis is concerned with the characteristics of cycles in financial variables within the South African context. The first chapter presents a taxonomy of the concepts of classical, deviation and growth rate cycles in order to establish a simple reference framework for cycle concepts. At this point the concept of a 'turning point cycle' is introduced, with particular focus on the non-parametric method of turning point identification, following Harding and Pagan's recent translation of the original work of Burns and Mitchell into a modern version with a sound statistical basis. With the turning points identified the dissertation proceeds to an exposition of descriptive measures of expansion and contraction phases. The second chapter entails an empirical report on descriptive results for amplitude and duration characteristics of cycle phases in the different financial variables, with separate reports for classical cycles and growth rate cycles. Chapter two concludes with a series of tables in which the behaviour of cycle phases are compared for different financial variables.

Part II considers financial variables as potential leading indicators of the business cycle in South Africa. Chapter 3 introduces the concept 'leading indicator' to this end and distinguishes the original concept from modern, econometric versions. The chapter then introduces a framework for evaluating potential leading indicators, which emphasises two requirements: firstly, broad co-movement between cycles in the proposed leading indicator and the business cycle and, secondly, stability in the number of months between turning points in cycles of the proposed indicator and business cycle turning points. The capacity of potential indicators to meet these criteria is measured via the concordance statistic and the 'lead profile' respectively. Chapter four provides the statistical basis for the concordance statistic, after which the 
empirical results (presented separately for classical and growth rate cycles) are presented. The fifth chapter presents the statistical test for the stability of the interval by which cyclical turning points in the potential indicator lead turning points in the business cycle. Empirical results are presented in both tabular form (the 'lead profile') and graphical form (the 'lead profile chart'). As far as can be determined, this analysis represents the first application of the 'lead profile' evaluation to financial variables. Chapter six concludes by presenting a summary of the results and a brief comparison with findings from an econometric study of leading indicators for South Africa. 


\section{OPSOMMING}

Hierdie tesis het ' $n$ tweeledige doelwit. Eerstens is dit gemik op 'n beskrywing van sikli in Suid-Afrikaanse finansiële veranderlikes en, tweedens, het dit die evaluering van verwantskappe tussen sodanige sikli (in finansiële veranderlikes) en die SuidAfrikaanse sakesiklus ten doel. Die analise is gegrond op die oorspronklike sakesiklus-denkraamwerk van Arthur Burns en Wesley Mitchell, met inagname van onlangse bydraes deur die Australiese ekonome Don Harding en Adrian Pagan, asook die werk van die Economic Cycle Research Institute in New York.

Deel I van die tesis is gemoeid met die eienskappe van sikli in finansiële veranderlikes binne die Suid-Afrikaanse bestel. In die eerste hoofstuk word die klassieke-, afwykings- en groeikoerssiklus-begrippe behandel ten einde 'n eenvoudige verwysingsraamwerk te vestig. Hierbenewens word die begrip 'draaipuntsiklus' breedvoerig beskryf, met die klem op nie-parametriese tegnieke van draaipuntidentifisering. Hierin word veral gesteun op die uiteensetting deur Don Harding and Adrian Pagan waarin die outeurs as oogmerk die verplasing van die oorspronklike werk van Burns en Mitchell na 'n moderne milieu (d.i. met 'n toepaslike statistiese grondslag) het. Vervolgens word "n reeks wiskundige maatstawwe bekendgestel wat in die beskrywing van uitbreidende en inkrimpende fases van sikli aangewend kan word. Die tweede hoofstuk omvat ' $\mathrm{n}$ empiriese verslag waarin eienskappe wat met die amplitude en tydsduur van hierdie siklusfases verband hou, behandel word. Resultate word afsonderlik vir die klassieke en groeikoers-sikli aangebied. Hierdie aanbieding word opgevolg met " $n$ reeks tabelle waarin vergelykings tussen die fasegedrag van sikli in verskillende finansiële veranderlikes getref word.

Deel II fokus op die evaluering van finansiële veranderlikes as leidende aanwysers van die sakesiklus. In hoofstuk 3 word die begrip 'leidende aanwyser' beskryf om dit te onderskei van verwante ekonometriese definisies. Hiernaas word die sistematiese evalueringsproses vir moontlike leidende aanwysers uiteengesit. In hierdie verband word voldoening aan veral twee vereistes beklemtoon: eerstens, breë ko-beweging tussen die sikli van die voorgenome aanwyser en die sakesiklus en, tweedens, stabiliteit in die aantal maande tussen draaipunte in sikli van die voorgenome aanwysers en sakesiklus-draaipunte. Voldoening aan hierdie vereistes word, 
onderskeidelik, deur middel van die konkordansie-statistiek en die 'leidende profiel' op 'n kwantitatiewe wyse gemeet. Die vierde hoofstuk omvat 'n breedvoerige uitleg van die statistiese grondslag vir die konkordansie-statistiek en word gevolg deur die empiriese resultate (afsonderlik aangebied vir klassieke en groeikoers-sikli). Die vyfde hoofstuk verskaf op soortgelyke wyse ' $n$ uiteensetting van die statistiese toets vir stabiliteit van die interval waarmee die siklusdraaipunte in die voorgenome aanwyser die sakesiklus-draaipunte voorafgaan. Vervolgens word empiriese resultate in beide tabelvorm (die 'leidende profiel') en grafiese vorm (die 'leidende profiel-kaart') aangebied. Hierdie ontleding verteenwoordig, sover vasgestel kon word, die eerste omskrewe toepassing van 'leidende profiele' in die evaluering van finansiële veranderlikes as leidende aanwysers. Hoofstuk 6 sluit af deur 'n samevatting van die verkreë resultate en ' $n$ vlugtige vergelyking met die bevindings van 'n ekonometriese studie van leidende aanwysers vir Suid-Afrika. 
ACKNOWLEDGEMENTS

I dedicate this work to the memory of my friend

Inge Lotz

Omnia ad majorem Dei gloriam

With the Hope of the Morning Star I have continued the journey.

I know your voice fills the halls of the Great Palace.

I know you sing as you love to do.

And when my knowledge has reached its bounds,

I will be guided by the Love and the Hope that shines in you for eternity.

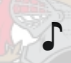

There are many that deserve my thanks at the end of this thesis:

I would like to express my gratitude towards my supervisor,

Professor Stanley du Plessis, who has thoroughly guided me in this scientific endeavour through suggestions of either a conceptual or statistical nature as well as with assistance in lucid expression.

Also, to my parents and sister who have lovingly supported me and have shown great interest in my work, my deepest thanks and love.

In addition I wish to thank Jac Laubscher for his suggestions on the list of variables to consider, Theo-Chris Groenewald for his help in obtaining time series data, as well as comments by participants at the 2005 Conference of the Economic Society of South Africa held from 7-9 September 2005 in Durban. 


\section{CONTENTS}

LIST OF TABLES

LIST OF FIGURES

LIST OF APPENDICES

$\begin{array}{lll}\text { PART I } & 17\end{array}$

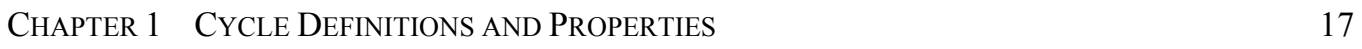

$1.1 \quad$ Conceptual clarification 17

I.2 Identification of cycles: different approaches 19

1.3 The non-parametric approach to turning point identification 21

$1.4 \quad$ Properties of cycles 22

Chapter 2 Properties of CyCles In FinANCIAL VARIABles: EMPIRICAL Results 26

$2.1 \quad$ Data and variables 26

$2.2 \quad$ Properties of classical cycles in financial variables 29

$2.3 \quad$ Properties of growth rate cycles in financial variables 34

$2.4 \quad$ Summary of cyclical properties of financial variables 36

$2.5 \quad$ Position in the literature 40

APPENDix A DATA AND SOURCES ? 44

APPENdix B TABles of CyCle Properties

\section{PART II THE LEADING INDICATOR PROPERTIES OF FINANCIAL VARIABLES 60}

$\begin{array}{lll}\text { CHAPTER } 3 & \text { FRAMEWORK FOR LEADING INDICATOR EVALUATION } & 61\end{array}$

$3.1 \quad$ Leading indicator concepts 61

$3.2 \quad$ Objective evaluation criteria 63

Chapter 4 CO-MOVEMENT BETWEen CyCLES In FINANCIAL VARIABLES AND CYCLES IN REAL ECONOMIC ACTIVITY $\quad 66$

$4.1 \quad$ Statistical methodology 66

4.2 Chronologies of South African cycles in real economic activity 69

4.3 Concordance of classical cycles in financial variables and cycles in real economic activity $\quad 69$

4.4 Concordance of growth rate cycles in financial variables and cycles in real economic activity $\quad 71$

4.5 Summary of concordance results 72

4.6 A cautionary remark 75

$4.7 \quad$ Comparison with previous concordance studies $\quad 75$

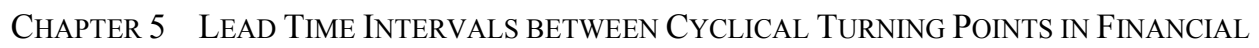


5.2 Matching of turning points and description of lead intervals 79

$5.3 \quad$ Statistical tests of lead intervals: methodology 83

$5.4 \quad$ Statistical test of lead intervals: results $\quad 87$

5.5 Comparison with previous South African studies $\quad 91$

CHAPTER 6 CONCLUSIONS 93

6.1 Comparison with South African probit results 93

$6.2 \quad$ Final conclusions 95

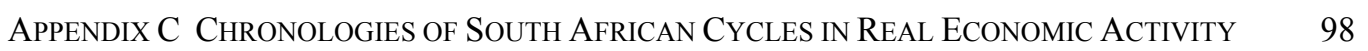

$\begin{array}{lr}\text { APPENDIX D EVALUATION OF BuSINESS CyCle CONFORMity } & 100\end{array}$

APPENDIX E EVALUATION OF LEAD TIMES 112

$\begin{array}{ll}\text { REFERENCES } & 119\end{array}$ 


\section{LIST OF TABLES}

TABLE 1 CLASSICAL CYCLE FEATURES OF MONETARY VARIABLES

TABLE 2 CLASSICAL CYCLE FEATURES OF LOCAL NOMINAL INTEREST RATES 46

TABLE 3 CLASSICAL CYCLE FEATURES OF LOCAL REAL INTEREST RATES 47

TABLE 4 CLASSICAL CYCLE FEATURES OF STOCK MARKET INDICES 48

TABLE 5 CLASSICAL CYCLE FEATURES OF LOCAL STOCK MARKET YIELDS

TABLE $6 \quad$ CLASSICAL CYCLE FEATURES OF LOCAL SPREADS

TABLE 7 CLASSICAL CYCLE FEATURES OF FOREIGN EXCHANGE RATES

TABLE $8 \quad$ CLASSICAL CYCLE FEATURES OF FOREIGN (US) INTEREST RATES 52

TABLE 9 TWELVE-MONTH GROWTH RATE CYCLE FEATURES OF MONETARY VARIABLES

TABLE 10 TWELVE-MONTH GROWTH RATE CYCLE FEATURES OF LOCAL

STOCK MARKET INDICES

TABLE 11 TWELVE-MONTH GROWTH RATE CYCLE FEATURES OF FOREIGN

STOCK MARKET INDICES

TABLE 12 TWELVE-MONTH GROWTH RATE CYCLE FEATURES OF FOREIGN

EXCHANGE RATES 56

TABLE 13 SUMMARY OF CLASSICAL CYCLE FEATURES FOR CONTRACTION PHASES RELATIVE TO EXPANSION PHASES (1)

TABLE 14 SUMMARY OF CLASSICAL CYCLE FEATURES FOR CONTRACTION PHASES RELATIVE TO EXPANSION PHASES (2) W 58

TABLE 15 SUMMARY OF GROWTH RATE CYCLE FEATURES FOR CONTRACTION PHASES RELATIVE TO EXPANSION PHASES

TABLE 16 DURATION AND AMPLITUDE OF CONTRACTIONS RELATIVE TO EXPANSIONS IN CLASSICAL CYCLES 38

TABLE 17 DURATION AND STEEPNESS OF CONTRACTIONS RELATIVE TO EXPANSIONS IN CLASSICAL CYCLES 38

TABLE 18 DURATION AND AMPLITUDE OF CONTRACTIONS RELATIVE TO EXPANSIONS IN GROWTH RATE CYCLES

TABLE 19 DURATION AND STEEPNESS OF CONTRACTIONS RELATIVE TO EXPANSIONS IN GROWTH RATE CYCLES

TABLE 20 COMPARISON OF DURATION AND AMPLITUDE OF PHASES IN SHARE PRICE INDICES IN SOUTH AFRICA AND THE DEVELOPED WORLD

TABLE 21 COMPARISON OF DURATION AND AMPLITUDE OF PHASES IN SHARE PRICE INDICES IN SOUTH AFRICA AND OTHER EMERGING MARKETS 42

TABLE 22 CONCORDANCE OF MONETARY VARIABLES AND REAL ECONOMIC ACTIVITY

TABLE 23 CONCORDANCE OF LOCAL NOMINAL INTEREST RATES AND REAL ECONOMIC ACTIVITY 101

TABLE 24 CONCORDANCE OF LOCAL REAL INTEREST RATES AND REAL ECONOMIC ACTIVITY 
TABLE 25 CONCORDANCE OF LOCAL JSE STOCK MARKET INDICES (IN LEVELS) AND REAL ECONOMIC ACTIVITY

TABLE 26 CONCORDANCE OF LOCAL JSE STOCK MARKET YIELDS (IN LEVELS) AND REAL ECONOMIC ACTIVITY 104

TABLE 27 CONCORDANCE OF LOCAL SPREADS (IN LEVELS) AND REAL ECONOMIC ACTIVITY

105

TABLE 28 CONCORDANCE OF FOREIGN EXCHANGE RATES (IN LEVELS) AND REAL ECONOMIC ACTIVITY

TABLE 29 CONCORDANCE OF INTERNATIONAL BOND AND STOCK MARKETS VARIABLES (IN LEVELS) AND REAL ECONOMIC ACTIVITY

TABLE 30 CONCORDANCE OF TWELVE-MONTH GROWTH RATES IN MONETARY VARIABLES WITH REAL ECONOMIC ACTIVITY

108

TABLE 31 CONCORDANCE OF TWELVE-MONTH GROWTH RATES IN LOCAL STOCK MARKET INDICES WITH REAL ECONOMIC ACTIVITY

109

TABLE 32 CONCORDANCE OF TWELVE-MONTH GROWTH RATES IN FOREIGN STOCK MARKET INDICES WITH REAL ECONOMIC ACTIVITY

TABLE 33 CONCORDANCE OF TWELVE-MONTH GROWTH RATES IN FOREIGN EXCHANGE RATES WITH REAL ECONOMIC ACTIVITY

TABLE 34 STATISTICALLY SIGNIFICANT LEADING INDICATORS (INDICATOR CYCLE IN CLASSICAL FORM) WITH OPTIMAL LEAD RANGES IN MONTHS

STATISTICALLY SIGNIFICANT LEADING INDICATORS (INDICATOR CYCLE IN TWELVE-MONTH GROWTH RATE FORM) WITH OPTIMAL LEAD RANGES IN MONTHS CONCORDANCE OF CLASSICAL CYCLES IN SHARE RETURNS INDICES AND GDP CONCORDANCE OF CLASSICAL CYCLES IN SHORT-TERM INTEREST RATES $A N D G D P$

TABLE 38

TIMING OF CYCLES IN FINANCIAL VARIABLES RELATIVE TO THE OFFICIAL $S A R B$ CYCLE

TABLE 39

TIMING OF CYCLES IN FINANCIAL VARIABLES RELATIVE TO THE GDP GROWTH RATE CYCLE

TABLE 40 TIMING OF CYCLES IN FINANCIAL VARIABLES RELATIVE TO THE INDUSTRIAL PRODUCTION CLASSICAL CYCLE

TABLE 41 TIMING OF CYCLES IN FINANCIAL VARIABLES RELATIVE TO THE INDUSTRIAL PRODUCTION GROWTH RATE CYCLE

TABLE 42 SUCCESS OF TURNING POINT MATCHING FOR CLASSICAL CYCLES IN FINANCIAL VARIABLES WITH CYCLES IN REAL ECONOMIC ACTIVITY

TABLE 43 SUCCESS OF TURNING POINT MATCHING FOR GROWTH RATE CYCLES IN FINANCIAL VARIABLES WITH CYCLES IN REAL ECONOMIC ACTIVITY ALL POSSIBLE PERMUTATIONS FOR TIMING DIFFERENCES BETWEEN PEAKS IN US 10-YEAR GOVERNMENT BOND YIELD CLASSICAL CYCLE AND PEAKS IN THE INDUSTRIAL PRODUCTION GROWTH RATE CYCLE 
TABLE 45 EXTREME PERMUTATIONS FOR TIMING DIFFERENCES BETWEEN PEAKS IN US 10-YEAR GOVERNMENT BOND YIELD CLASSICAL CYCLES 86

TABLE 46 THE RANGE OF NULL HYPOTHESES FOR LEADS OF DIFFERENT DURATIONS

TABLE 47 LEAD PROFILE OF CYCLES IN FINANCIAL VARIABLES RELATIVE TO THE OFFICIAL SARB CYCLE

TABLE 48 LEAD PROFILE OF CYCLES IN FINANCIAL VARIABLES RELATIVE TO THE GDP GROWTH RATE CYCLE

TABLE 49 LEAD PROFILE OF CYCLES IN FINANCIAL VARIABLES RELATIVE TO THE INDUSTRIAL PRODUCTION CLASSICAL CYCLE

TABLE 50 LEAD PROFILE OF CYCLES IN FINANCIAL VARIABLES RELATIVE TO THE INDUSTRIAL PRODUCTION GROWTH RATE CYCLE

TABLE 51 SUMMARY OF LEAD INTERVAL FINDINGS FOR CLASSICAL CYCLES IN FINANCIAL VARIABLES

TABLE 52 SUMMARY OF LEAD INTERVAL FINDINGS FOR GROWTH RATE CYCLES IN FINANCIAL VARIABLES

TABLE 53 SCORE CLASSIFICATION FOR LEAD TIME CONSISTENCY

TABLE 55 SCORING RESULTS FOR FINANCIAL VARIABLES THAT PERFORMED THE BEST LEAD INTERVALS SUGGESTED BY CONCORDANCE STATISTIC (THIS STUDY) AND PROBIT MODEL (MOOLMAN (2003)) 


\section{LIST OF FIGURES}

FIGURE 1 LEAD PROFILE CHART OF GROWTH RATE CYCLE TROUGHS IN THE REAL EFFECTIVE RAND RELATIVE TO TROUGHS IN THE INDUSTRIAL PRODUCTION CLASSICAL CYCLE

FIGURE 2 LEAD PROFILE CHART OF GROWTH RATE CYCLE PEAKS IN THE REAL RAND-DOLLAR EXCHANGE RATE RELATIVE TO PEAKS IN THE INDUSTRIAL PRODUCTION CLASSICAL CYCLE

FIGURE 3 LEAD PROFILE CHART OF CLASSICAL CYCLE PEAKS IN US 10-YEAR GOVERNMENT BOND YIELD RELATIVE TO PEAKS IN THE INDUSTRIAL PRODUCTION GROWTH RATE CYCLE 


\section{LIST OF APPENDICES}

APPENDIXA DATA AND SOURCES 44

APPENDIX B TABLES OF CYCLE PROPERTIES 45

APPENDIXC CHRONOLOGIES OF SOUTH AFRICAN CYCLES IN

REAL ECONOMIC ACTIVITY 98

$\begin{array}{lll}\text { APPENDIX D EVALUATION OF BUSINESS CYCLE CONFORMITY } & 100\end{array}$

APPENDIXE EVALUATION OF LEAD TIMES 112 


\section{INTRODUCTION}

Over the past twenty years and more, economists have studied linkages between the financial and real sectors of the economy to improve business cycle forecasting on the one hand and portfolio allocation on the other. This study contributes to this literature by analysing cyclicality in financial markets and its relation to the cyclical behaviour of the South African real economy. There is more than one tradition in business cycle analysis and this study falls within the turning point cycle tradition, whereby the relevant series are divided into successive expansions and contractions, separated by turning points (troughs and peaks).

The first goal of the study is a description of the cyclical behaviour of relevant variables using measures of amplitude and duration. Such a descriptive study is a backward-looking method to establish stylised facts - allowing comparison of current cycle phases with features of historical cycles (see Bry and Boschan, 1971: 65-78). The cycle phases of South African financial variables have not been investigated in this manner, though these stylised facts have, to a limited extent, been established internationally. Notably, Pagan and Sossounov (2003) have described bull and bear phases in the stock markets of industrialised nations, while Edwards et al (2003) perform similar analyses for six emerging markets in Latin America and Asia.

The assets traded on financial markets are complex claims on the real economy and cyclical variation in financial variables may, therefore, be related to the business cycle in the real economy. Hence, the second goal of the study is a thorough evaluation of the relationships between cycles in financial variables and the South African business cycle - an investigation that may identify financial variables that can act as leading indicators of economic activity. These leading indicators - originally proposed by Burns and Mitchell in 1938 (see Del Negro, 2001) - are now used by most central banks, including the South African Reserve Bank (SARB) (see Van der Walt, 1984). Moolman (2003) and Moolman and Jordaan (2005) are recent South African examples concerned with assessing the suitability of several macroeconomic variables (including selected financial variables) in predicting turning points in the real economy and the stock market respectively. This study attempts to identify suitable financial predictor variables using two criteria: first, the co-movement between cycles 
in financial variables and the business cycles and, second, the consistency in the interval with which turning points in financial variable cycles lead business cycle turning points.

Part I of the study pursues the first aim, i.e. a thorough description of cycle phases in South African and relevant international financial variables. Part II attends to the second goal of an evaluation of the leading indicator properties of such financial variables relative to cycles in South African real economic activity. 


\section{PART I CYCLES IN FINANCIAL VARIABLES}

\section{CHAPTER 1 CYCLE DEFINITIONS AND PROPERTIES}

The investigation of the descriptive statistics of cycle phases in financial variables on the one hand as well as their co-movement with cycles in the real economy on the other both require a clear concept of the term "cycle". The wide variety of cycle definitions as well as inconsistency in applying a particular definition has undermined the plausibility of conclusions in the literature (see Harding and Pagan, 2005 and Canova, 1998). This proliferation of business cycle concepts has opened a gap between how academic economists and market practitioners view cyclicality in economic variables (Harding and Pagan, 2001: 2). Harding and Pagan have recently tried to overcome this gap from the side of academic economists, and this dissertation follows their lead in the South African context.

To bridge this gap Harding and Pagan (e.g. 2001 and 2005) have suggested a nomenclature of business cycle concepts, which attends to two central themes in cycle analysis:

(i) The format of the economic time series in which cycles are to be identified.

(ii) The approach to identification and description of cycles in the series.

Although these questions are related, they are treated separately in the following sections - section 1.1 attends to the format of economic time series and section 1.2 attends to cycle identification.

\subsection{CONCEPTUAL Clarification}

In their taxonomy of business cycle concepts, Harding and Pagan (2005) distinguish between classical, deviation and growth rate cycles. Classical cycles refer to cycles in the levels of the relevant variables and these are the cycles that were analysed by the pioneers of modern business cycle analysis - Burns and Mitchell (1946). The classical cycle has two important advantages relative to other cycle concepts. Firstly, the classical cycle has intuitive plausibility, as it corresponds with the intuitive understanding of business cycle phases as alternating periods of prosperity and 
depression shared by economists, policy makers and the general public (Harding and Pagan (2005)). Secondly, classical cycle analysis does not entail any data transformation or subsequent loss of information - making the approach computationally simple, transparent and repeatable.

The problem with transforming time series is demonstrated by considering the deviation cycle concept, which has dominated cycle research over the past two decades. Deviation cycle analysis starts with the identification of a permanent component. Once identified, this permanent component is subtracted from the original series - leaving (typically) a serially correlated set of deviations, called a deviation cycle. However, Harding and Pagan (2004) have emphasised the nonuniqueness of identifying permanent components with various filters, such as the Hodrick-Prescott, Beveridge-Nelson and band-pass filters. For example, they argue that a particular unit root series ${ }^{1}$ may be decomposed non-uniquely into another unit root series plus a stationary process (Harding and Pagan, 2004: 7) ${ }^{2}$.

While these arguments against deviation cycles are strong, Artis et al (2005) argue that classical cycles might present problems of identification too, since declines in the absolute level of economic activity may be rather exceptional events in series that are strongly upward trending. This argument also applies to certain financial variables (such as monetary aggregates) and indicates that a growth rate cycle investigation may be worthwhile. Such growth rate cycles entail alternative periods of accelerating and decelerating growth (Osborn et al 2005: 62).

It should be noted that growth rates are essentially filters in which previous values of the original series are taken implicitly as the permanent component. Therefore, although growth rate cycles do not escape the critique of Harding and Pagan (2004)

\footnotetext{
${ }^{1}$ A unit root series refers to a time series with a stochastic trend. This is a "smooth" time series (Granger 2003) for which a shock at a particular point in time has a permanent effect on the series (see Hayashi 2004: 557-558).

${ }^{2}$ Consider a series such as $\Delta y_{t}=e_{t}+\alpha e_{t-1}$. In this case, the permanent component produced by the Beveridge-Nelson decomposition is $\Delta y_{t}^{p}=(1+\alpha) e_{t}$. Consequently, the de-trended series will also be a function of $e_{t}$ and, therefore, a function of the particular definition of the permanent component.
} 
against deviation cycles entirely, this study implements a pragmatic approach by augmenting the classical cycle viewpoint with a growth rate cycle analysis for strongly trending series. However, for those series (including yields and spreads) that are not strongly trending only classical cycles are identified. This pragmatic approach corresponds to the approach by Osborn et al (2005) and Andreou et al (2000).

\subsection{IDENTIFICATION OF CYCLES: DIFFERENT APPROACHES}

Following a decision on the type of cycle, the particular method used to identify and describe the cycle becomes important. The Harding-Pagan taxonomy (2005) identifies three approaches in identifying cycles:

(i) Models assuming sinusoidal periodicity.

(ii) Cycle identification by reference to turning points (i.e. peaks and troughs).

(iii) Methods based on output cycles as "serially correlated deviations of output from trend" (Blinder and Fischer 1981: 227).

The approach in (i) assumes a particular data generating process for the real economy and uses a combination of sine and cosine curves to replicate the cyclical behaviour of the real economy. The restrictive assumptions concerning the data generating process, though, are difficult to defend and this study will not entertain this approach further (see Pagan (2004)).

Harding and Pagan commit the bulk of their attention to turning point cycles (as described in (ii) above). Following the seminal work by Burns and Mitchell (1946), this approach involves dividing the relevant economic time series into successive expansions and contractions, separated by peaks and troughs (called turning points). This intuitive method, however, lost ground to approach (iii) as academic economists attempted to improve macro-econometric modelling - which required assumptions of linear stochastic data generating processes. Critics of the second approach (and proponents of the third viewpoint) even claimed that turning point cycles do not have an adequate statistical basis (see Blanchard \& Fisher (1989)).

Recently, however, the turning point cycle concept has regained importance in academic literature - primarily through the work of Harding and Pagan (e.g. 2001, 
2002 and 2005) who have addressed concerns about the statistical underpinning of turning point cycle analysis. It appears that while macroeconometric modelling has offered insights into the behaviour of economic "fluctuations" (to use the term favoured by proponents of approach (iii)), the turning point cycle approach continues to offer useful, alternative evidence on short-term developments in the economy.

The turning point cycle approach is applied by business cycle dating committees around the world (Artis et al 2004). The computerised version of the procedure is still in use at the National Bureau of Economic Research (NBER) and is formally described in Bry and Boschan (1971). The South African Reserve Bank also employs turning points in deviation cycles ${ }^{3 ; 4}$ in the official dating process for the South African business cycle (Venter 2005b: 61; Mohr 2000: 69). The SARB's algorithm is an information-rich one, based on a large number of economic time series, rather than a single measure of aggregate activity, such as gross domestic product $^{5}$. Venter $(2005 \mathrm{~b})$ provides an account of the SARB's methodology, and as Harding and Pagan $(2001 ; 2002 ; 2005)$ observed, this type of turning point analysis is typical to the dating committees of many central banks.

The Burns-Mitchell method of turning point analysis is a non-parametric procedure. Parametric techniques, however, have dominated the turning point cycle literature in recent years - particularly since the development of the Markov-switching method (see Hamilton 1989). While parametric models are important in forecasting applications, they may add unnecessary complexity when study goals are restricted to dating and describing cycles. Pagan (2004: 22) also questions the transparency of parametric models, pointing to the absence of clear rules when compared with the calculus rules of the non-parametric method (see the next section). In addition,

\footnotetext{
${ }^{3}$ The permanent component is calculated via the Phase Average Trend (PAT) method (Venter 2005a).

${ }^{4}$ Harding and Pagan show that turning points in deviation cycles may, in some cases, be identical to turning points in classical cycles. This situation could arise when amplitude-censoring rules are applied to deviation cycle data so as to remove minor cycles (Harding and Pagan, 2004: 8).

5 Nonetheless, the turning point chronology in the GDP deviation cycle (that is, after a linear deterministic trend has been removed) obtained by Du Plessis (2004) corresponds closely with the set of deviation cycle turning points identified by the Bank's information-rich approach.
} 
turning points identified by Markov-switching models are sample and model dependent, as models may be adapted to find in-sample turning points that are identical to, for example, official turning points and may produce different turning points for different specifications.

The analysis of turning point cycles in real economic activity suggests the possibility of identifying turning point cycles in financial variables in a similar manner. This study investigates turning points in both the levels and the growth rates of financial time series using the non-parametric Bry-Boschan procedure as outlined in the next section.

\subsection{The Non-Parametric Approach to Turning Point Identification}

The Bry-Boschan (1971) algorithm was recently applied to the South African business cycle by Du Plessis (2004 and 2005). In essence, the algorithm involves a calculus rule - to identify peaks and troughs in a series $\left\{x_{t}\right\}^{6}$ - as well as a set of censoring rules to distinguish business cycles from other fluctuations in the economic time series. Indeed, Burns and Mitchell (1946: 57) emphasised that duration of the phases and total cycle is the primary characteristic by which to identify business cycle fluctuations.

The method identifies turning points in $\left\{x_{t}\right\}$ which are either smaller or larger than a window of $k$ surrounding values. That is, a peak is identified at time $t$ if

$$
\left\{\left(x_{t-k}, \ldots, x_{t-1}\right)<x_{t}>\left(x_{t+1}, \ldots, x_{t+k}\right)\right\}
$$

and a trough at time $t$ if

$$
\left\{\left(x_{t-k}, \ldots, x_{t-1}\right)>x_{t}<\left(x_{t+1}, \ldots, x_{t+k}\right)\right\}
$$

\footnotetext{
${ }^{6}$ Or $\left\{\log x_{\mathrm{t}}\right\}$, as the method is invariant to a log transformation (Harding and Pagan 2001).
} 
The size of $k$ is arbitrary, but Bry and Boschan (1971) suggest an optimal size of five or six for monthly data. Pagan and Sossounov (2002), however, propose $k=8$ as the most appropriate for monthly data on stock markets. While this study uses a window width of six months, the results were checked against the alternative window of eight months and found to be robust.

Applying this technique to financial variables requires additional censoring rules to ensure that spurious cycles are not identified (Harding and Pagan 2001). Following Pagan and Sossounov (2002) as well as Edwards et al (2003), the censoring rules differ from the Bry-Boschan censoring rules in two ways - both related to the volatile nature of financial time series. Firstly, this study does not perform outlier-adjustment - as extreme movements in financial time series (as opposed to real economic activity variables) are not uncommon. Outlier-adjustment essentially results in a loss of information, although it does have the advantage of removing data errors. Secondly, the censoring rule pertaining to the minimum length of a phase is overridden in cases of extreme movements (see censoring rule (iv) below).

The following list summarises the censoring rules used for financial variables in this study:

(i) Turning points within four months of the beginning/end of the series are eliminated.

(ii) Complete cycles with total duration shorter than fifteen months are eliminated.

(iii) Phases shorter than six months are eliminated, except for excessive ${ }^{7}$ falls/rises where a minimum phase length of four months applies.

\subsection{Properties of CyCles}

Once turning points have been identified and a series divided into successive periods of expansion and contraction the properties of the cycles identified in this way are open to description and analysis. The properties of such cycles may be described through horizontal (or duration-related) phase statistics and vertical (or amplituderelated) phase statistics. Most of these statistics (horizontal and vertical) describe the

\footnotetext{
7 "Excessive" is defined as a rise or fall in the series that exceeds twenty percent $(20 \%)$.
} 
cycle phases, while some (e.g. the variability measures) gauge the degree to which cycles follow a typical pattern in a particular series.

As a preliminary step to calculating descriptive statistics, a binary variable, $s_{t}$, is defined taking the value unity if there is an expansion in the series at time $t$ and 0 if the series is contracting (Edwards et al 2003; Pagan and Sossounov 2002). To serve as input in the calculation of cycle statistics, the following ancillary statistics are defined:

(i) The total time spent in an expansion is $\sum_{t=1}^{T} s_{t}$ and total time spent in a contraction is $\sum_{t=1}^{T} b_{t}$ where $b_{t}=1-s_{t}$.

(ii) The number of peaks (or expansions), i.e. the number of trough-to-peak movements, is given by $N T P=\sum_{t=1}^{T-1}\left(1-S_{t+1}\right) s_{t}-$ since the series $\left(1-s_{t+1}\right) s_{t}$ equals unity in the case of a peak at time $t$, i.e. when $s_{t}=1, s_{t+1}=0$ (Harding and Pagan 2001). Similarly, the number of troughs (or contractions), i.e. the number of peak-to-trough movements, is given by $N P T=\sum_{t=1}^{T-1}\left(1-b_{t+1}\right) b_{t}$.

These measures are now used to estimate horizontal statistics, of which duration $(D)$ is the most important. Note that the population value of $D$ for a particular phase is unknown and must be estimated by calculating the sample average duration $(\hat{D})$, such that the average duration for an expansion phase is:

$$
\hat{D}^{\text {expansion }}=N T P^{-1} \sum_{t=1}^{T} s_{t}
$$

Several additional duration characteristics are reported, including maximum and minimum duration, the proportion of time spent in either phase as well as the average duration of an expansion relative to a preceding contraction (Du Plessis 2004: 27). 
Similar statistics for contraction phases are calculated by replacing NTP with NPT and $s_{t}$ with $b_{t}$ (this applies to both horizontal and vertical statistics).

The horizontal characteristics are then supplemented by vertical statistics to provide a two-dimensional description of cycle phases. The amplitude $(A)$ and steepness $(\Omega)$ measures for cycle phases are again estimated by calculating the sample average amplitude $(\hat{A})$ and steepness $(\hat{\Omega})$ for each phase:

$$
\begin{aligned}
& \hat{A}^{\text {expansion }}=N T P^{-1} \sum_{t=1}^{T} s_{t} \Delta\left(x_{t}\right) \\
& \hat{\Omega}^{\text {expansion }}=\frac{\hat{A}^{\text {expansion }}}{\hat{D}^{\text {expansion }}}
\end{aligned}
$$

Another vertical characteristic is the volatility or "noisiness" measure $(V)$ proposed by Edwards et al (2003). The sample volatility $(\hat{V})$ of an expansion phase is defined as the average magnitude of the monthly change (with a similar definition applying to a contraction phase):

$$
\hat{V}^{\text {expansion }}=\frac{1}{\sum_{t=1}^{T} s_{t}} \sum_{t=1}^{T} s_{t}\left|\Delta x_{t}\right|
$$

Since this statistic is based on absolute values, it prevents occasional negative (positive) movements from being hidden by the generally positive (negative) movements in the series. It is, therefore, comparable to the steepness measure - if the value is much larger than the absolute value of steepness the series may be considered relatively noisy. The proportion of phases with amplitude higher than a particular threshold is also reported (see Chapter 2).

A final statistic is the variability measure $(\Gamma)$ for duration and amplitude. This statistic assesses the similarity of phase duration (amplitude) to average phase duration (amplitude), thereby highlighting information that may have been lost during the averaging process. The sample variability $(\hat{\Gamma})$ of duration (or amplitude) is 
closely related to the coefficient of variation and is unitless (Pagan 2004). This is useful for a comparison of the dispersion of values in two series. For an expansionary phase in duration it is estimated as:

$$
\hat{\Gamma}_{D}^{\text {expansion }}=\frac{\sqrt{N T P^{-1} \sum_{i=1}^{N T P}\left(\hat{D}_{i}^{\text {expansion }}-\bar{D}^{\text {expansion }}\right)^{2}}}{N T P^{-1} \sum_{i=1}^{N T P} \hat{D}_{i}^{\text {expansion }}}
$$

Similar statistics can be calculated for contraction phases and for amplitude (instead of duration).

This chapter has presented various cycle concepts in the international literature and has introduced several statistics to measure different aspects of cyclical behaviour. The following chapter provides an empirical study of the properties of turning point cycles in financial variables based on these descriptive statistics. 


\section{CHAPTER 2 PROPERTIES OF CYCLES IN FINANCIAL VARIABLES: EMPIRICAL RESULTS}

\subsection{DATA AND VARIABLES}

The statistical properties of financial variables are investigated using monthly data, while quarterly real GDP is used as a measure of real economic activity. The frequency mismatch between GDP and the financial variables inevitably results in a loss of information. Hence, monthly industrial production data was also used to describe the output cycle, though industrial production does not sufficiently reflect the structure of the South African economy.

As discussed, growth rate cycles for selected variables will also be investigated. Osborn et al (2005: 65) argue that both three- and twelve-month growth rates should be considered in order to capture shorter- and longer-term movements in variables. However, the dataset contains unsmoothed series that may yield noisy short-term growth rates and in practice empirical results tended to be similar for three-month and twelve-month rates for the data at hand. Consequently, this study restricts attention to twelve-month growth rates based on differences in the levels or logarithmic levels of the series.

This study, focusing on South African financial time series, follows the variables proposed by Sarantis and Lin (1999) and Andreou et al (2000). Variables include series from the domestic bond, stock and foreign exchange markets, as well as domestic monetary variables and a few series from international financial markets. Appendix A contains a full specification of variables and data sources, while the following paragraphs provide an overview of monetary aggregate, interest rate, stock market and exchange rate variables used.

\subsubsection{Monetary sector}

In the monetary sector, real M1 and M3 monetary aggregates are considered; the M2 money measure is excluded given its close movement with the M3 measure. Various 
interest rates, including short-term and long-term interest rates as well as the term structure of interest rates (i.e. the yield curve) are investigated.

The analysis of interest rates distinguishes between nominal and real interest rates (nominal rates adjusted for expected inflation). This distinction raises the difficult issue of measuring inflation expectations. Conventionally, the real interest rate is calculated by subtracting the inflation rate of the most recent period from the current nominal interest rate, using inflation in the most recent period as the relevant measure of expected inflation. In their investigation of South African real interest rates Kahn and Farrell (2002) suggest four alternative approaches to measure inflation expectations:

(i) Using the inflation rate of the current period to generate ex post real rates.

(ii) Forecasting inflation using a time series filter, such as the Hodrick-Prescott filter.

(iii) Using survey data on inflation expectations as a proxy.

(iv) Exploiting the implied inflation expectations from index-linked government bonds.

However, Kahn and Farrell (2002) report that different proxies for inflation expectations do not yield materially different results for South Africa for the period 1993 to 2000. Du Plessis (2004) confirms their South African findings with additional results based on the ex-ante real rate proposed by Romer and Romer (1994). Hence, this study will apply the conventional technique in the calculation of real rates.

The yield curve is calculated as the difference between long- and short-term interest rates (Sarantis and Lin, 1999: 92; Chauvet and Potter, 2005: 77). Alternatively, the yield curve can be calculated on a relative basis as the ratio of the long-short interest rate difference and the short-term rate. However, as results for the absolute and relative bases were found to be similar, this dissertation reports the results for the absolute basis only. 


\subsubsection{Stock market}

Stock market variables include share price indices, dividend yields, price-to-earnings ratios as well as reverse yield gaps. The reverse yield gap is defined as the difference between the dividend yield and long-term interest rates (Sarantis and Lin, 1999: 92) and is proposed to account for the impact of inflation on returns in the bond market relative to the stock market.

\subsubsection{International markets}

From the foreign currency market, the rand-dollar exchange rate and the effective exchange rate of the rand are investigated. From the international financial markets, selected US stock market indices, interest rates and interest rate differentials are analysed. Representative indices for emerging stock and bond markets are also considered.

The sample period for the series normally runs from 1986 to 2004, although sample periods may start as recent as 1995 for a few variables. Series are seasonally adjusted where needed ${ }^{8}$ (compare with Andreou et al (2000: 399)). The choice of the sample period is determined by the move from a liquid asset ratio-based monetary policy regime to a more market-based regime around 1985 (Aron and Muellbauer, 2002).

The following two sections contain reports on the descriptive statistics for the classical cycles (Section 2.1) and growth rate cycles (Section 2.2) in each of the financial variables mentioned above. The exposition is extensive by necessity, as it is only through analysis from different perspectives that reliable inferences concerning cyclical behaviour can be produced. Section 2.4 summarises the main results from these sections and attempts a comparison of expansion and contraction features in the different variables.

\footnotetext{
${ }^{8}$ It is worth noting that the results from unadjusted versus seasonally-adjusted series need not yield divergent results. Christiano and Todd (2002) illustrate that a seasonal time series generated by a stylised business cycle model has second-moment properties that match those of seasonally-adjusted macroeconomic data fairly well.
} 


\subsection{Properties of Classical Cycles in Financial VARIABLes}

The interpretation of the descriptive statistics should be preceded by some cautionary remarks. Firstly, consecutive cycles could be quite dissimilar, such that the average value hides much of the variability in either duration or amplitude. Therefore, it is important to assess the variability (of duration or amplitude) in conjunction with the average value (of duration or amplitude). Secondly, the amplitude measure tends to be positively related to duration. Hence, a comparison of amplitude and steepness measures could offer a more objective view of vertical movement.

Tables 1 to 8 are contained in Appendix B. Table 1 reports the classical cycle characteristics for the real M1 and M3 monetary aggregates. Considering horizontal characteristics first, contraction phases appear to be, on average, shorter than expansion phases. This is clear from the average duration, relative length of expansions versus contractions as well as from the proportion of time spent in contraction. The variability of both contraction and expansion duration is higher for real M3 - which suggests that duration of individual cycle phases in the real M1 money supply are more similar to the average duration than for the real M3 measure. The average duration is therefore more representative of most cycles in the real M1 aggregate.

As far as vertical characteristics are concerned, average amplitude of contractions appear to be lower than expansions for both M1 and M3. The steepness measure, however, suggests that contractions are steeper than expansions - illustrating the duration-bias of the amplitude measure as discussed earlier. The evidence on variability of amplitude is mixed: the amplitude of contraction phases in M1 and expansion phases in M3 appear to be less variable. The average amplitude of M1 contractions and M3 expansions are therefore more representative. The volatility measure for all the variables and phases are larger than the absolute values of the steepness measures. This illustrates the noisiness of classical cycles in real monetary aggregates. Contraction phases, though, appear to be less noisy (especially for M3) than expansion phases. 
Table 2 shows the classical cycle features of South African nominal interest rates. Considering horizontal characteristics, all characteristics support the conclusion that downward phases have longer duration than upward phases for the twelve-month and ten-year nominal interest rates. Downward phase duration for these two variables is also less variable than for upward phases - especially for the ten-year yield. This stands in contrast with the experience of the three-month interest rate. The latter exhibits slightly shorter average duration for downward phases relative to upward phases, but the variability of downward phase duration is much higher than for upward phases in this case. Compared to the other two variables, however, upward phases in the three-month interest rate are less variable.

As far as vertical characteristics are concerned, average amplitude of downward phases appear to be higher than for upward phases for all nominal interest rates. However, this is again duration-biased, as only the three-month interest rate is steeper (and only slightly so) compared to upward phases. The upward and downward phases for the three rates exhibit fairly similar variability of amplitude. Noisiness, as measured by the volatility statistic, is not excessive for downward phases, though upward phases in nominal interest rates are relatively noisier.

Table 3 reports the classical cycle characteristics of South African real interest rates. The duration of downward phases in the real three-month interest rate is substantially longer than for upward phases. For the real twelve-month interest rate downward phases are shorter than upward phases, while the duration of downward and upward phases in the real ten-year interest rate are similar. The variability of the downward phase duration is higher for the real three- and twelve-month interest rates and substantially lower for the real ten-year interest rate. This suggests that average duration is more representative for downward phases in the real ten-year interest rate and for upward phases in the other two rates.

Considering the vertical dimension, average amplitude of downward phases appears to be lower than upward phases for all real interest rates. The steepness measure, however, provides less certainty - it only confirms shallower downward phases for the real three-month and ten-year rates. The volatility measure for all of the variables 
and phases is larger than the absolute value of the steepness measure indicating that classical cycles in real interest rates are fairly noisy.

Table 4 contains the classical cycle features of stock market indices. All statistics confirm that contractions are much shorter than expansions. The variability of contraction duration is lower for the JSE All Share Index, but higher for all of the other indices. Moreover, expansion duration variability is relatively low for the MSCI index compared to the JSE indices. These suggest that duration of individual contraction phases in the JSE All Share Index and individual expansion phases in the MSCI index are similar to their respective average values. For these particular phases, the average duration is therefore more representative.

As far as vertical characteristics are concerned, the average amplitude of contractions appears to be much lower than for expansions in all of the stock market indices. The steepness measure, however, shows that contractions are steeper - due to much lower contraction durations. Furthermore, classical cycles in stock market indices appear to be noisy in both expansions and contractions. The evidence on variability of amplitude is again mixed: amplitude of contraction phases in the JSE Resources Index and MSCI Emerging Market Index are lower than for expansion phases - especially for the Resources Index. The amplitude of expansion phases in the JSE All Share Index as well as the Financial and Industrial Index is lower than for contractions. In sum, contraction amplitude in the first two and expansion amplitude in the last two are fairly representative of most cycles.

Table 5 presents the descriptive statistics for the dividend yield and price-earnings ratio of the JSE All Share Index. From a horizontal perspective, all of the statistics support the conclusion that the duration of contraction phases in the dividend yield is slightly longer than for expansion phases. For the price-earnings ratio, expansions and contractions appear to have similar length - with different statistics pointing to different conclusions. Duration variability is substantially lower for both phases of the classical cycle in the dividend yield when compared to the price-earnings ratio. The average duration is therefore more representative of most cycles in the dividend yield. The more regular properties of the dividend yield cycle (compared with the 
price-earnings ratio) may be related to the practice of smoothing dividend payouts (see, for example, Blake (2003: 196-198)).

Considering vertical characteristics, average amplitude of contractions appear to be lower for both the dividend yield and the price-earnings ratio, although it is more accentuated in the case of the dividend yield. Contraction and expansion phases for both variables do not appear to differ in terms of steepness. In addition, the volatility measure is relatively high - pointing to fairly noisy classical cycles in both variables. The variability of amplitude in the dividend yield is lower than the price-earnings ratio. The average amplitude is therefore more representative of most cycles in the dividend yield.

In Table 6 the classical cycle characteristics of local spreads are reported. Considering horizontal characteristics, the contraction phases in the yield curve and reverse yield gap appear to be longer than expansion phases, although some statistics, such as the average relative length of expansions versus previous contractions do not support this conclusion. As far as the variability of duration is concerned, the reverse yield gap exhibits slightly less variability in contraction durations relative to the durations of expansions. For the yield curve, expansion duration is less variable though again not accentuated.

From a vertical perspective, both the yield curve and reverse yield gap has higher average contraction amplitude. The variability of expansion amplitude in the yield curve classical cycle is lower than for contractions. This suggests that the average expansion amplitude for the yield curve is more representative than average contraction amplitude. The variability of the reverse yield gap is similar in expansions and contractions. The steepness measure indicates that steepness does not differ substantially between contraction and expansion phases for both the yield curve and reverse yield gap. The reverse yield gap appears to be fairly noisy.

Table 7 discusses the features of classical cycles in the real rand-dollar exchange rate and the real effective rand exchange rate. Horizontally, depreciation phases last longer in both cases. For the real effective rand this means generally longer contraction phases (as declines in effective exchange rates represent depreciations), 
while the real rand-dollar rate experiences generally longer expansion phases. These conclusions are generally supported by all other horizontal characteristics. As far as the real rand-dollar is concerned, duration variability is generally low and similar for depreciation and appreciation phases, while appreciation (expansion) phases in the real effective rand appear to be more variable. In sum, the average duration is representative of expansion and contraction duration in the real rand-dollar exchange rate as well as for consecutive depreciation (contraction) phases in the real effective rand.

From a vertical perspective, average amplitude is substantially higher during depreciation phases for both exchange rates. Controlling for duration, the steepness measures confirm this notion, although some duration bias appear to be present in both cases. Amplitude variability is notably lower for depreciation phases, testifying to the representativeness of average depreciation amplitude.

Table 8 reports the classical cycle features of foreign (US) interest rates. For the USSouth Africa interest rate differential the average contraction duration is shorter than for expansions. This is supported by all of the descriptive statistics. The variability of contraction duration is also much lower compared to expansionary phases implying that average contraction duration is fairly representative of most cycles. Considering the US interest rates, it appears that contractions last longer than expansions. The evidence from the average duration, relative length of expansions versus contractions and proportion of time spent in either phase are especially strong for the US ten-year government bond yield, with mixed evidence for the US federal funds rate. The variability of duration is low for expansions in both interest rates as well as for contractions in the long-term rate. This indicates that the average duration is a fairly good representation of actual cycle durations.

As far as vertical characteristics are concerned, average contraction amplitude for the foreign interest rate differential appears to be slightly lower, with similar steepness and little noise in both phases. The variability of expansion duration is much lowerindicating that average expansion duration is more representative of specific cycles. For the US interest rate, average contraction amplitude is substantially higher than for expansions. The steepness measure offers mixed evidence - pointing to duration-bias 
in the average amplitude. The volatility measure indicates relatively uniform series. The US ten-year government bond yield exhibits substantially less amplitude variability than the US federal funds rate. This suggests that average amplitude is more representative for long-term, as opposed to short-term, US interest rates.

\subsection{Properties of Growth Rate Cycles in Financial Variables}

We now proceed to investigate the properties of growth rate cycles in selected financial variables in order to construct stylised facts similar to the ones established for the classical cycles in financial variables.

Tables 9 to 12 are contained in Appendix B. Table 9 reports the growth rate cycle characteristics of the real M1 and M3 monetary aggregates. Considering horizontal characteristics, contraction phases appear to be, on average, shorter than expansion phases, though the results are more conclusive for M1. The variability of duration is similar for contractions and expansions M1 and slightly higher for M3 contractions as opposed to expansions.

From the vertical perspective, average amplitude of contractions appears to be lower than for expansions in both M1 and M3. The steepness measure, though, indicate that contractions are, generally, as steep as expansions. The evidence on the variability of amplitude shows that amplitude of contractions phases is lower in the case of M1 and substantially lower in the case of M3. The average amplitude of contractions in the growth rate cycle of monetary aggregates is therefore fairly representative. The volatility measures indicate that growth rate cycles in real monetary aggregates are noisy.

Table 10 contains the growth rate cycle features of local stock market indices. Contraction durations appear to be similar to that of expansions. The average contraction duration is slightly longer for JSE All Share Index as well as the Financial and Industrial Index. The additional statistics, however, indicate similar duration for the expansions and contractions. For the JSE All Share Index and the Financial and Industrial Index the variability is lower for expansions, while the opposite applies to the case of the Resources Index. 
As far as vertical characteristics are concerned, the average amplitude does not differ substantially between expansions and contractions. The Resource Index, however, exhibit much larger amplitude (for both phases) compared to the other indices. The last conclusion is supported by the steepness measure, though it appears that expansion phases are steeper than contraction phases for the All Share Index and the Financial and Industrial Index. The volatility measure is relatively high - pointing to fairly noisy growth rate cycles in all three indices.

Table 11 presents the descriptive statistics for the S\&P 500 Share Price Index, the MSCI Emerging Market Share Price Index and the JP Morgan Emerging Market Bond Index. The statistics do not yield a uniform picture on duration. It appears that contraction durations are similar to expansion durations in the growth rate cycle of the S\&P 500 and the JP Morgan EMBI. The contraction phases in the MSCI EMSI appear to last slightly longer, but all of the statistics do not support this conclusion. The variability of duration in the case of the MSCI growth rate cycle is similar for expansion and contractions and is also much lower than for both phases in the other two indices, implying that the average duration is relatively representative of individual phase duration in both MSCI expansions and contractions.

The amplitude, as a measure of vertical variability, can be used as a proxy for investment risk in the different stock market cycles reported in Tables 11 and 12. Therefore, a comparison of phase amplitude for the different stock markets provides a picture of relative risk in these markets. Average amplitudes appear to increase from the S\&P 500 (lowest value) to the JP Morgan EMBI (middle value) to the MSCI Emerging Market Share Index (highest value), but are similar for expansions and contractions. The steepness measures yield a similar order, with volatility measures indicating relatively noisy cycles. These results are consistent with the following propositions:

(i) Investment risk is lower for American shares and higher for emerging market bonds. This is expected, given the difference in economic and political risk in emerging markets relative to the United States.

(ii) Investment risk is lower for emerging market bonds and higher for emerging market shares. This is expected, given that the income stream from bonds is contractually fixed, while the income stream from share dividends is not. 
A comparison of amplitudes in Table 12 with amplitude behaviour of the South African stock market (as reported in Table 11) shows that average phase amplitude for the JSE All Share Index is higher than for the JP Morgan EMBI, but much lower than for the MSCI Emerging Market Share Index. This implies that investment risk for the South African stock market (measured in this way) is lower than for emerging stock markets in general, though still higher than for emerging market bonds.

Table 12 shows that contraction phases in the growth rates of both the nominal and real rand-dollar exchange rates are longer. In addition, corresponding expansion phases in the effective exchange rate are shorter ${ }^{9}$. All of these imply that, in general, depreciation periods for the South African exchange rate have lasted longer than subsequent appreciation phases. Throughout, the steepness measure confirms that average amplitudes are not duration-biased. Depreciation periods appear to have higher steepness relative to appreciation periods. No stylised facts concerning the shape of a particular phase can be discerned for any of the exchange rates.

\subsection{Summary of CyClical Properties of Financial Variables}

Interpretation of the stylised facts presented here requires a lucid understanding of the unique macroeconomic context within which any particular cycle arises. The economist should be forewarned not to confound the extent of regularity and recurrence in economic series with the idea that consecutive cycles are alike. Such cases may well exist, but it is safe to heed the warning of Burns (1969: 24): "It is also well to keep in mind, first, that the generalizations emphasize the repetitive features of the economic changes that takes place during business cycles; second, that they merely express strong tendencies toward repetition - not invariant rules of behaviour." The focus is not so much on the quantitative values per se as it is on creating descriptive measures that are readily comparable across series.

Tables 13 and 14 describe the salient features of classical cycles and Table 15 of growth rate cycles in South African financial variables (all of the tables are contained in Appendix B). In effect, the tables offer an explicitly narrow summary of the much

\footnotetext{
${ }^{9}$ Although the recent appreciation phase of the Rand is evident from the growth rate cycles, the last turning point is removed to enable comparison with the classical cycles in the following section.
} 
larger body of individual cycle research described at length in Sections 2.2 and 2.3. The tables report whether contractions have lower, similar, or higher average duration (column 1), average amplitude (column 5) and steepness (column 6) compared to expansions. Column 2 shows whether the duration conclusions in column 1 are mainly supported by two other statistics, namely:

(i) The average length of an expansion relative to a preceding contraction phase.

(ii) The proportion of time spent in either phase.

Variability measures for duration (columns 3 and 4) and amplitude (columns 7 and 8) are also reported to illustrate the extent to which contraction and expansion phases are similar to the average value.

Tables 16 and 17 clarify the relationships between duration, amplitude and steepness of classical cycles as implied in Tables 13 and 14. The exposition in Table 16 illustrates duration-amplitude relationships. The focus is on the total effect of a particular phase movement (as measured by amplitude), rather than on the intensity of such movement (as measured by steepness). Amplitude may be duration-biased, i.e. longer phases may have higher amplitude, perhaps because longer duration allows more time for amplitude to accumulate. Table 17 accounts for this problem by summarising the duration-steepness relationships implied by Tables 13 and 14. Those variables that hold the same position in both Tables 16 and 17 are reported in bold. 
Table 16:

Duration and amplitude of contractions relative to expansions in classical cycles

\begin{tabular}{|c|c|c|c|}
\hline \multirow{2}{*}{$\begin{array}{l}\text { CONTRACTION } \\
\text { AMPLITUDE } \\
\text { VS } \\
\text { EXPANSIONS }\end{array}$} & \multicolumn{3}{|c|}{$\begin{array}{c}\text { CONTRACTION DURATION } \\
\text { VS } \\
\text { EXPANSIONS } \\
\end{array}$} \\
\hline & Shorter & Similar & Longer \\
\hline Lower & $\begin{array}{c}\text { Real 12-m NCD rate } \\
\text { Real 3-m TB yield } \\
\text { Foreign interest rate } \\
\text { differential } \\
\text { Real M1 } \\
\text { Real M3 } \\
\text { JSE All Share Index } \\
\text { JSE Fin and Industrial } \\
\text { Index } \\
\text { JSE Resources Index } \\
\text { MSCI Emerging Market } \\
\text { Real Rand-Dollar } \\
\end{array}$ & $\begin{array}{c}\text { Real 10-yr govt bond } \\
\text { yield } \\
\text { JSE ALSI dividend yield }\end{array}$ & \\
\hline Similar & & JSE ALSI P:E Ratio & \\
\hline Higher & & $\begin{array}{c}\text { 3-month Treasury bill } \\
\text { yield }\end{array}$ & $\begin{array}{c}\text { 12-m NCD rate } \\
\text { 10-yr govt bond yield } \\
\text { Yield curve } \\
\text { Reverse yield gap } \\
\text { US Federal Funds rate } \\
\text { US 10-yr govt bond } \\
\text { yield } \\
\text { Real effective rand }\end{array}$ \\
\hline
\end{tabular}

Table 17:

Duration and steepness of contractions relative to expansions in classical cycles

\begin{tabular}{|c|c|c|c|}
\hline \multirow{2}{*}{$\begin{array}{c}\text { CONTRACTION } \\
\text { STEEPNESS } \\
\text { VS } \\
\text { EXPANSIONS }\end{array}$} & $\mathrm{C}$ & $\begin{array}{c}\text { NTRACTION DURATI } \\
\text { VS } \\
\text { EXPANSIONS } \\
\end{array}$ & \\
\hline & Shorter & Similar & Longer \\
\hline Lower & $\begin{array}{c}\text { Real Rand-Dollar } \\
\text { Real 3-m Treasury bill } \\
\text { yield }\end{array}$ & $\begin{array}{c}\text { Real 10-year govt bond } \\
\text { yield }\end{array}$ & $\begin{array}{c}\text { 12-m NCD interest rate } \\
\text { 10-year govt bond yield } \\
\text { US } 10 \text {-year govt bond } \\
\text { yield }\end{array}$ \\
\hline Similar & $\begin{array}{c}\text { Real 12-m NCD interest } \\
\text { rate } \\
\text { Foreign interest rate } \\
\text { differential }\end{array}$ & $\begin{array}{l}\text { JSE ALSI Dividend } \\
\text { Yield } \\
\text { JSE ALSI P:E Ratio }\end{array}$ & $\begin{array}{c}\text { Yield Curve } \\
\text { Reverse Yield Gap } \\
\text { US Federal Funds rate }\end{array}$ \\
\hline Higher & $\begin{array}{c}\text { Real M1 } \\
\text { Real M3 } \\
\text { JSE All Share Index } \\
\text { JSE Fin and Industrial } \\
\text { Index } \\
\text { JSE Resources Index } \\
\text { MSCI Emerging Market }\end{array}$ & 3-m Treasury bill yield & Real Effective Rand \\
\hline
\end{tabular}

Tables 18 and 19 show similar illustrations for growth rate cycles. Those variables that hold the same position in both Tables 18 and 19 are reported in bold: 
Table 18:

Duration and amplitude of contractions relative to expansions in growth rate cycles

\begin{tabular}{|c|c|c|c|}
\hline $\begin{array}{c}\text { CONTRACTION } \\
\text { AMPLITUDE } \\
\text { VS } \\
\text { EXPANSIONS }\end{array}$ & \multicolumn{3}{|c|}{$\begin{array}{c}\text { CONTRACTION DURATION } \\
\text { VXPANSIONS }\end{array}$} \\
\cline { 2 - 4 } Lower & Shorter & Similar & Longer \\
\hline & Real M1 & $\begin{array}{c}\text { Real M3 } \\
\text { S\&P 500 Share Index } \\
\text { JP Morgan Emerging } \\
\text { Bond }\end{array}$ & $\begin{array}{c}\text { JSE All Share Index } \\
\text { JSE Fin and } \\
\text { Industrial Index } \\
\text { Real Effective Rand }\end{array}$ \\
\hline Similar & $\begin{array}{c}\text { Rond } \\
\text { Higher }\end{array}$ & $\begin{array}{c}\text { MSCI Emerging } \\
\text { Share }\end{array}$ \\
\hline & $\begin{array}{c}\text { Real Rand-Dollar } \\
\text { Nominal Rand- } \\
\text { Dollar }\end{array}$ & JSE Resources Index & \\
\hline
\end{tabular}

Table 19:

Duration and steepness of contractions relative to expansions in growth rate cycles

\begin{tabular}{|c|c|c|c|}
\hline \multirow{2}{*}{$\begin{array}{l}\text { CONTRACTION } \\
\text { STEEPNESS } \\
\text { VS } \\
\text { EXPANSIONS }\end{array}$} & \multicolumn{3}{|c|}{$\begin{array}{l}\text { CONTRACTION DURATION } \\
\text { VS } \\
\text { EXPANSIONS }\end{array}$} \\
\hline & Shorter & Similar & Longer \\
\hline Lower & & & $\begin{array}{l}\text { JSE All Share Index } \\
\text { JSE Fin and Industrial } \\
\text { Index } \\
\text { MSCI Emerging Share } \\
\text { Real Effective Rand }\end{array}$ \\
\hline Similar & Real M1 & $\begin{array}{c}\text { Real M3 } \\
\text { S\&P 500 Share Index } \\
\text { JP Morgan Emerging } \\
\text { Bond }\end{array}$ & \\
\hline Higher & $\begin{array}{l}\text { Real Rand-Dollar } \\
\text { Nominal Rand-Dollar }\end{array}$ & JSE Resources Index & \\
\hline
\end{tabular}

The following discussion highlights selected conclusions, many of which are not controversial:

(a) In South Africa depreciation phases have dominated cycles in exchange rates. Such phases last longer, have greater effect (higher amplitude) and are more intense (steeper) relative to periods of appreciation. Initially, growth rate analysis appears to contradict this position. However, after removal of the final turning point capturing the recent appreciation phase, the growth rate 
cycle suggest interpretations similar to the classical cycle (which does not share such a turning point).

(b) Where the JSE is concerned, bear market phases in the local All Share as well as the Financial and Industrial Share price indices are shorter and steeper relative to bull market phases, but their overall effects (i.e. their amplitude) are smaller. These align with the duration findings for emerging markets such as Brazil and Chile (see Edwards et al, 2003). Furthermore, the growth rate cycle suggests that growth deceleration phases last longer and are less intensive. Hence, slowdown in stock market performance (excluding Resources) is more subtle and prolonged when considered in proportional, rather than absolute, terms.

(c) Phases in the classical cycle of the All Share dividend yield and price-earnings ratio are similar in duration, amplitude and steepness and demonstrate the stability of stock market yields relative to share price indices.

\subsection{POSITION IN THE LITERATURE}

Here the focus is restricted to a summary of studies based on the non-parametric method to describe cycles in financial variables. While the business cycle literature boasts numerous attempts to describe amplitude and duration features of business cycles, similar investigations on cycles in financial variables are surprisingly scant. Moreover, such studies only consider cycles in stock market indices.

A seminal paper by Pagan and Sossounov (2002) demonstrated that non-parametric business cycle dating techniques can be applied to investigate the cyclical features of an equivalent of the S\&P 500 share price index. Gómez Biscarri and Pérez de Gracia (2003) followed with a study on the features of the Spanish stock market compared to UK, US and German stock markets. These authors then united with Edwards (see Edwards, Gómez Biscarri and Pérez de Gracia, 2003) to compare the features of emerging stock market cycles prior to and following financial liberalization. 
Tables 20 and 21 compare the behaviour of classical cycles in South African share price indices with classical cycles in several industrial and emerging share price indices taken from the above-mentioned studies. It is worth noting that comparisons are fruitless where sample periods differ substantially from the sample periods of the South African variables. Hence, the findings of Pagan and Sossounov (2002), based on a sample period running from 1835 to 1997, is not reported.

Table 20 presents the average duration and amplitude for expansion and contraction phases in US, UK, German and Spanish share price indices (Gómez Biscarri and Pérez de Gracia, 2003: 22) as well as the South African stock market variables discussed earlier. Note that the South African All Share Index, arguably the most useful for comparison purposes, exhibit much shorter expansion phases than the US, UK or Germany. Expansion duration, however, is closer to the Spanish stock market. Contraction durations in the ALSI is shorter than for the UK, Germany and Spain and slightly shorter compared to the US.

Duration of classical cycle phases (for both expansions and contractions) in the SA Financial and Industrial Index are comparable to the Spanish stock market, while the behaviour of expansion and contraction duration in the SA Resources Index tends to be closer to the German stock market.

Table 20:

Comparison of duration and amplitude of phases in share price indices in South Africa and the developed world

\begin{tabular}{|l|l|r|r|r|r|}
\hline \multirow{2}{*}{ Country } & \multirow{2}{*}{ Sample period } & \multicolumn{2}{|c|}{ Average duration } & \multicolumn{2}{c|}{ Average amplitude } \\
\cline { 3 - 6 } & & Expansion & Contraction & Expansion & Contraction \\
\hline USA & $88.01-01.09$ & 47.3 & 7.7 & 0.68 & -0.19 \\
\hline UK & $89.09-01.09$ & 34.0 & 10.8 & 0.52 & -0.23 \\
\hline Germany & $88.02-01.09$ & 30.0 & 11.0 & 0.72 & -0.33 \\
\hline Spain & $89.10-00.02$ & 20.3 & 10.5 & 0.71 & -0.27 \\
\hline SA ALSI & $86.01-04.12$ & 16.5 & 6.1 & 0.41 & -0.27 \\
\hline SA Fin \& Ind & $87.01-04.12$ & 20.7 & 9.0 & 0.51 & -0.29 \\
\hline SA Resources & $86.01-04.12$ & 28.5 & 14.8 & 0.85 & -0.48 \\
\hline
\end{tabular}

Source: Gómez Biscarri and Pérez de Gracia (2003); own calculations in italics

As far as amplitude measures are concerned, the All Share Index as well as the Financial and Industrial Index seem comparable to the UK stock market. The 
Resources index, though, exhibit much larger amplitude (in both expansion and contraction phases) compared to all of the stock markets in the developed world.

Similar statistics for emerging equity markets are obtained from Edwards et al (2003: 45). Table 21 reports the duration and amplitude measures for Argentina, Brazil, Chile, Mexico, South Korea and Thailand during the so-called post-liberalisation sample period (with financial liberalisation dates proposed by Bekaert and Harvey, 2000). These are presented together with the South African variables as well as the MSCI Emerging Market share price index.

Table 21:

Comparison of duration and amplitude of phases in share price indices in South Africa and other emerging share markets

\begin{tabular}{|l|l|r|r|r|r|}
\hline \multirow{2}{*}{ Country } & \multirow{2}{*}{ Sample period } & \multicolumn{2}{|c|}{ Average duration } & \multicolumn{2}{c|}{ Average amplitude } \\
\cline { 3 - 6 } & & Expansion & Contraction & Expansion & Contraction \\
\hline Argentina & $89.11-01.01$ & 25.5 & 10.0 & 1.18 & -0.69 \\
\hline Brazil & $91.05-01.01$ & 16.5 & 17.0 & 0.91 & -1.29 \\
\hline Chile & $92.01-01.01$ & 17.5 & 12.0 & 0.70 & -0.38 \\
\hline Mexico & $89.05-01.01$ & 17.7 & 29.5 & 0.83 & -1.19 \\
\hline South Korea & $92.01-01.01$ & 29.3 & 10.0 & 1.20 & -0.76 \\
\hline Thailand & $87.09-01.01$ & 19.7 & 16.0 & 0.87 & -1.16 \\
\hline SA ALSI & $86.01-04.12$ & 16.5 & 6.1 & 0.41 & -0.27 \\
\hline SA Fin \& Ind & $87.01-04.12$ & 20.7 & 9.0 & 0.51 & -0.29 \\
\hline SA Resources & $86.01-04.12$ & 28.5 & 14.8 & 0.85 & -0.48 \\
\hline MSCI Emerge & $87.12-04.12$ & 31.3 & 10 & 0.72 & -0.55 \\
\hline
\end{tabular}

Source: Edwards et al (2003); own calculations in italics

Expansion duration in the ALSI and Financial and Industrial share price index are similar to expansions in Brazil, Chile, Mexico and Thailand. Expansion duration in the Resources share price index is comparable to the MSCI Emerging Market index as well as the Argentinean and South Korean share price indices. Contraction durations are relatively low for the All Share index, while contractions in the other South African indices appear similar to other emerging market stock indices (excluding Mexico).

The amplitude of expansion and contraction phases in South African share price indices is generally lower than for other emerging equity markets. We do find, however, that the Chilean stock market may be the closest (in this sample) to South African stock market variables in terms of amplitude. These results confirm that the South African stock market (possibly excluding the Resources index) is quite 
advanced vis-à-vis other emerging markets and show that comparisons with lowerrank developed markets such as Spain could prove useful.

Phase statistics have been calculated for expansion and contraction phases separately. Past studies have revealed that these phases may bear close resemblance to expansions and contractions in cycles of real economic activity. In fact, official leading indicators of the business cycle in industrialised and emerging countries include several financial variables (Venter and Pretorius (2004), Andreou et al (2000), Mohr (2000: 71-74)). Part II will attempt an evaluation of the leading indicator properties of South African financial variables based on the turning point cycles derived in Part I. 


\section{APPENDIX A: DATA AND SOURCES}

\begin{tabular}{|c|c|c|c|}
\hline Description & Source & Frequency & Dates \\
\hline \multicolumn{4}{|l|}{ Real variables } \\
\hline Industrial Production, seasonally adjusted & SARB & Monthly & $01 / 86-12 / 04$ \\
\hline Gross Domestic Product, seasonally adjusted & SARB & Quarterly & $01 / 86-12 / 04$ \\
\hline Consumer Price Index, seasonally adjusted & SARB & Monthly & $01 / 86-12 / 04$ \\
\hline \multicolumn{4}{|l|}{ Money market } \\
\hline Money supply M1, seasonally adjusted & SARB & Monthly & $01 / 86-12 / 04$ \\
\hline Money supply M3, seasonally adjusted & SARB & Monthly & $01 / 86-12 / 04$ \\
\hline \multicolumn{4}{|l|}{ Bond market } \\
\hline 3 month Treasury bill yield & SARB & Monthly & $01 / 86-12 / 04$ \\
\hline 12 month Negotiable Certificate of Deposit interest rate & SARB & Monthly & $01 / 86-12 / 04$ \\
\hline Government Bonds long-term yield (10 years) & SARB & Monthly & $01 / 86-12 / 04$ \\
\hline \multicolumn{4}{|l|}{ Foreign exchange market } \\
\hline Rand-Dollar Exchange Rate & SARB & Monthly & $01 / 86-12 / 04$ \\
\hline Rand Effective Exchange Rate & SARB & Monthly & $01 / 90-12 / 04$ \\
\hline \multicolumn{4}{|l|}{ Stock market } \\
\hline JSE-FTSE All Share Index & MGBFA & Monthly & $01 / 86-12 / 04$ \\
\hline JSE-FTSE Financial and Industrial Index & MGBFA & Monthly & $01 / 87-12 / 04$ \\
\hline JSE-FTSE Resources Index & MGBFA & Monthly & $01 / 86-12 / 04$ \\
\hline JSE-FTSE All Share Index - dividend yield & MGBFA & Monthly & $01 / 86-12 / 04$ \\
\hline JSE-FTSE All Share Index - price-earnings ratio & MGBFA & Monthly & $01 / 86-12 / 04$ \\
\hline \multicolumn{4}{|l|}{ International variables } \\
\hline S\&P 500 & MGBFA & Monthly & $07 / 88-12 / 04$ \\
\hline US Federal Funds Rate & MGBFA & Monthly & $01 / 86-12 / 04$ \\
\hline US Government Bonds long-term yield (10 years) & MGBFA & Monthly & $01 / 86-12 / 04$ \\
\hline MSCI Emerging Market Share Index & MSCI & Monthly & $12 / 87-12 / 04$ \\
\hline JP Morgan Emerging Market Bond Index & REUTERS & Monthly & $12 / 90-12 / 04$ \\
\hline
\end{tabular}

Notes: SARB, South African Reserve Bank;

MSCI, Morgan Stanley Capital International;

MGBFA, McGregor-BFA database 


\section{APPENDIX B: TABLES OF CYCLE PROPERTIES}

Table 1:

Classical cycle features of monetary variables

\begin{tabular}{|c|c|c|c|c|}
\hline \multirow[t]{2}{*}{ Characteristic } & \multicolumn{2}{|c|}{ Contraction } & \multicolumn{2}{|c|}{ Expansion } \\
\hline & Real M1 & Real M3 & Real M1 & Real M3 \\
\hline \multicolumn{5}{|l|}{ Horizontal } \\
\hline Average duration & 8.8 & 16 & 24.3 & 30 \\
\hline Maximum duration & 13 & 42 & 41 & 59 \\
\hline Minimum duration & 6 & 7 & 10 & 10 \\
\hline Variability of duration & 0.28 & 0.94 & 0.48 & 0.6 \\
\hline Expansions: contractions $\mathrm{s}^{\mathrm{a}}$ & 2.72 & 1.93 & 2.72 & 1.93 \\
\hline Proportion $^{\mathrm{b}}$ & 0.27 & 0.35 & 0.73 & 0.65 \\
\hline \multicolumn{5}{|l|}{ Vertical } \\
\hline Average amplitude & $-11.96 \%$ & $-7.46 \%$ & $29.68 \%$ & $24.16 \%$ \\
\hline Variability of amplitude & 0.25 & 0.65 & 0.53 & 0.38 \\
\hline Steepness & $-1.35 \%$ & $-0.47 \%$ & $1.22 \%$ & $0.81 \%$ \\
\hline Volatility & $2.15 \%$ & $1.10 \%$ & $2.64 \%$ & $1.19 \%$ \\
\hline Proportion $^{\mathrm{c}}$ & 0 & 0 & 0.83 & 0.75 \\
\hline
\end{tabular}

Average duration of an expansion relative to preceding contraction Proportion of time spent in either phase

Proportion of phases with amplitude greater than $20 \%$ 
Table 3:

Classical cycle features of local real interest rates

\begin{tabular}{|c|c|c|c|c|c|c|}
\hline \multirow[t]{2}{*}{ Characteristic } & \multicolumn{3}{|c|}{ Contraction } & \multicolumn{3}{|c|}{ Expansion } \\
\hline & $\begin{array}{c}\text { Real } \\
3 \text { month } \\
\text { Treasury } \\
\text { Bill Yield } \\
\end{array}$ & $\begin{array}{l}\text { Real } 12 \mathrm{~m} \\
\text { NCD } \\
\text { Interest } \\
\text { Rate }\end{array}$ & $\begin{array}{c}\text { Real } \\
10 \text { year } \\
\text { Govt } \\
\text { Bond Yield } \\
\end{array}$ & $\begin{array}{c}\text { Real } \\
3 \text { month } \\
\text { Treasury } \\
\text { Bill Yield } \\
\end{array}$ & $\begin{array}{l}\text { Real } 12 \mathrm{~m} \\
\text { NCD } \\
\text { Interest } \\
\text { Rate } \\
\end{array}$ & $\begin{array}{c}\text { Real } \\
10 \text { year } \\
\text { Govt } \\
\text { Bond Yield } \\
\end{array}$ \\
\hline \multicolumn{7}{|l|}{ Horizontal } \\
\hline Minimum duration & 10 & 5 & 8 & 5 & 6 & 4 \\
\hline Variability of duration & 0.73 & 0.56 & 0.37 & 0.52 & 0.44 & 0.63 \\
\hline Expansions:contractions ${ }^{\mathrm{a}}$ & 0.79 & 1.70 & 0.95 & 0.79 & 1.70 & 0.95 \\
\hline Variability of amplitude & 0.49 & 0.39 & 0.47 & 0.51 & 0.54 & 0.48 \\
\hline Steepness & $-25 b p$ & -42 bp & $-37 b p$ & $37 \mathrm{bp}$ & $42 \mathrm{bp}$ & $46 \mathrm{bp}$ \\
\hline Volatility & $49 \mathrm{bp}$ & $57 \mathrm{bp}$ & $55 \mathrm{bp}$ & $56 \mathrm{bp}$ & $64 \mathrm{bp}$ & $67 \mathrm{bp}$ \\
\hline Proportion $^{\mathrm{c}}$ & 0.67 & 0.57 & 0.63 & 0.40 & 0.50 & 0.43 \\
\hline $\begin{array}{l}\text { Average duration of } \\
\text { Proportion of time sp } \\
\text { Proportion of phases }\end{array}$ & $\begin{array}{l}\text { on relative to } \\
\text { er phase } \\
\text { itude greater }\end{array}$ & $\begin{array}{l}\text { ceding contra } \\
500 \text { basis po }\end{array}$ & & & & \\
\hline
\end{tabular}


Table 4:

Classical cycle features of stock market indices

\begin{tabular}{|c|c|c|c|c|c|c|c|c|}
\hline \multirow[t]{2}{*}{ Characteristic } & \multicolumn{4}{|c|}{ Contraction } & \multicolumn{4}{|c|}{ Expansion } \\
\hline & $\begin{array}{c}\text { JSE } \\
\text { All } \\
\text { Share } \\
\text { Index }\end{array}$ & $\begin{array}{c}\text { JSE } \\
\text { Financial \& } \\
\text { Industrial } \\
\text { Index }\end{array}$ & $\begin{array}{c}\text { JSE } \\
\text { Resources } \\
\text { Index }\end{array}$ & $\begin{array}{c}\text { MSCI } \\
\text { Emerging } \\
\text { Market } \\
\text { Share Index }\end{array}$ & $\begin{array}{c}\text { JSE } \\
\text { All } \\
\text { Share } \\
\text { Index }\end{array}$ & $\begin{array}{c}\text { JSE } \\
\text { Financial \& } \\
\text { Industrial } \\
\text { Index }\end{array}$ & $\begin{array}{c}\text { JSE } \\
\text { Resources } \\
\text { Index }\end{array}$ & $\begin{array}{c}\text { MSCI } \\
\text { Emerging } \\
\text { Market } \\
\text { Share Index }\end{array}$ \\
\hline \multicolumn{9}{|l|}{ Horizontal } \\
\hline Average duration & 6.1 & 9 & 14.8 & 10 & 16.5 & 20.7 & 28.5 & 31.3 \\
\hline Maximum duration & 11 & 20 & 30 & 18 & 30 & 40 & 51 & 46 \\
\hline Minimum duration & 4 & 4 & 6 & 4 & 4 & 8 & 14 & 19 \\
\hline Variability of duration & 0.37 & 0.57 & 0.62 & 0.58 & 0.51 & 0.48 & 0.48 & 0.36 \\
\hline Expansions:contractions ${ }^{\mathrm{a}}$ & 3.18 & 3.75 & 2.53 & 6.25 & 3.18 & 3.75 & 2.53 & 6.25 \\
\hline Proportion $^{b}$ & 0.29 & 0.34 & 0.39 & 0.30 & 0.71 & 0.66 & 0.61 & 0.70 \\
\hline \multicolumn{9}{|l|}{ Vertical } \\
\hline Average amplitude & $-26.65 \%$ & $-28.92 \%$ & $-48.44 \%$ & $-54.72 \%$ & $41.01 \%$ & $51.15 \%$ & $85.31 \%$ & $72.45 \%$ \\
\hline Variability of amplitude & 0.57 & 0.64 & 0.30 & 0.42 & 0.37 & 0.41 & 0.56 & 0.51 \\
\hline Steepness & $-4.36 \%$ & $-3.21 \%$ & $-3.27 \%$ & $-5.47 \%$ & $2.49 \%$ & $2.48 \%$ & $2.99 \%$ & $2.31 \%$ \\
\hline Volatility & $6.54 \%$ & $4.70 \%$ & $5.08 \%$ & $7.73 \%$ & $4.58 \%$ & $3.98 \%$ & $5.29 \%$ & $4.03 \%$ \\
\hline Proportion $^{\mathrm{c}}$ & 0.44 & 0.57 & 1.0 & 1.0 & 1.0 & 0.83 & 1.0 & 1.0 \\
\hline $\begin{array}{l}\text { Average duration of } \\
\text { Proportion of time sp } \\
\text { Proportion of phases }\end{array}$ & $\begin{array}{l}\text { on relative to } \\
\text { er phase } \\
\text { itude greater }\end{array}$ & $\begin{array}{l}\text { eceding contrac } \\
\text { n } 20 \%\end{array}$ & & & & & & \\
\hline
\end{tabular}


Table 5:

Classical cycle features of local stock market dividend yield and P:E ratio

\begin{tabular}{|c|c|c|c|c|}
\hline \multirow[t]{2}{*}{ Characteristic } & \multicolumn{2}{|c|}{ Contraction } & \multicolumn{2}{|c|}{ Expansion } \\
\hline & $\begin{array}{c}\text { JSE } \\
\text { All Share } \\
\text { Dividend } \\
\text { Yield } \\
\end{array}$ & $\begin{array}{c}\text { JSE } \\
\text { All Share } \\
\text { P:E } \\
\text { Ratio } \\
\end{array}$ & $\begin{array}{c}\text { JSE } \\
\text { All Share } \\
\text { Dividend } \\
\text { Yield }\end{array}$ & $\begin{array}{c}\text { JSE } \\
\text { All Share } \\
\text { P:E } \\
\text { Ratio }\end{array}$ \\
\hline \multicolumn{5}{|l|}{ Horizontal } \\
\hline Average duration & 20.5 & 18.5 & 16.5 & 19.2 \\
\hline Maximum duration & 39 & 41 & 32 & 56 \\
\hline Minimum duration & 13 & 4 & 9 & 4 \\
\hline Variability of duration & 0.52 & 0.98 & 0.55 & 0.71 \\
\hline Expansions:contractions ${ }^{\mathrm{a}}$ & 0.82 & 1.69 & 0.82 & 1.69 \\
\hline Proportion $^{\mathrm{b}}$ & 0.55 & 0.54 & 0.45 & 0.46 \\
\hline \multicolumn{5}{|l|}{ Vertical } \\
\hline Average amplitude & $-47.25 \%$ & $-44.97 \%$ & $37.16 \%$ & $43.38 \%$ \\
\hline Variability of amplitude & 0.35 & 0.46 & 0.47 & 0.51 \\
\hline Steepness & $-2.31 \%$ & $-2.43 \%$ & $2.25 \%$ & $2.26 \%$ \\
\hline Volatility & $4.78 \%$ & $4.18 \%$ & $4.83 \%$ & $4.01 \%$ \\
\hline Proportion $^{\mathrm{c}}$ & 1.0 & 1.0 & 0.75 & 0.83 \\
\hline
\end{tabular}

Average duration of an expansion relative to preceding contraction

Proportion of time spent in either phase

Proportion of phases with amplitude greater than $20 \%$ 
Table 6:

Classical cycle features of local spreads

\begin{tabular}{|c|c|c|c|c|c|c|}
\hline \multirow[t]{2}{*}{ Characteristic } & \multicolumn{3}{|c|}{ Contraction } & \multicolumn{3}{|c|}{ Expansion } \\
\hline & $\begin{array}{l}\text { Yield } \\
\text { Curve }\end{array}$ & $\begin{array}{l}\text { Reverse } \\
\text { Yield } \\
\text { Gap }\end{array}$ & $\begin{array}{c}\text { Real } \\
\text { Reverse } \\
\text { Yield } \\
\text { Gap }\end{array}$ & $\begin{array}{l}\text { Yield } \\
\text { Curve }\end{array}$ & $\begin{array}{l}\text { Reverse } \\
\text { Yield } \\
\text { Gap }\end{array}$ & $\begin{array}{c}\text { Real } \\
\text { Reverse } \\
\text { Yield } \\
\text { Gap }\end{array}$ \\
\hline \multicolumn{7}{|l|}{ Horizontal } \\
\hline Minimum duration & 5 & 8 & 6 & 9 & 4 & 6 \\
\hline Variability of duration & 0.68 & 0.54 & 0.29 & 0.59 & 0.69 & 0.52 \\
\hline Expansions:contractions ${ }^{\mathrm{a}}$ & 1.10 & 1.14 & 1.76 & 1.10 & 1.14 & 1.76 \\
\hline \multicolumn{7}{|l|}{ Vertical } \\
\hline Variability of amplitude & 0.50 & 0.37 & 0.44 & 0.38 & 0.40 & 0.44 \\
\hline Steepness & $-2 b p$ & $-27 b p$ & $-55 b p$ & $2 \mathrm{bp}$ & $31 \mathrm{bp}$ & $37 \mathrm{bp}$ \\
\hline Volatility & $3 \mathrm{bp}$ & $45 \mathrm{bp}$ & $69 \mathrm{bp}$ & $3 \mathrm{bp}$ & $46 \mathrm{bp}$ & $68 \mathrm{bp}$ \\
\hline Proportion $^{\mathrm{c}}$ & 0 & 0.14 & 0.83 & 0 & 0.29 & 0.71 \\
\hline $\begin{array}{l}\text { Average duration of } \\
\text { Proportion of time sp } \\
\text { Proportion of phases }\end{array}$ & $\begin{array}{l}\mathrm{n} \text { relative } \mathrm{t} \\
\mathrm{r} \text { phase } \\
\text { ude greater }\end{array}$ & $\begin{array}{l}\text { eding contr } \\
500 \text { basis } p\end{array}$ & & & & \\
\hline
\end{tabular}


Table 7:

Classical cycle features of foreign exchange rates

\begin{tabular}{|c|c|c|c|c|}
\hline \multirow[t]{2}{*}{ Characteristic } & \multicolumn{2}{|c|}{ Contraction } & \multicolumn{2}{|c|}{ Expansion } \\
\hline & $\begin{array}{c}\text { Real } \\
\text { Effective } \\
\text { Exchange } \\
\text { Rate } \\
\end{array}$ & $\begin{array}{c}\text { Real Rand } \\
\text { Dollar } \\
\text { Exchange } \\
\text { Rate }\end{array}$ & $\begin{array}{c}\text { Real } \\
\text { Effective } \\
\text { Exchange } \\
\text { Rate } \\
\end{array}$ & $\begin{array}{l}\text { Real Rand } \\
\text { Dollar } \\
\text { Exchange } \\
\text { Rate } \\
\end{array}$ \\
\hline \multicolumn{5}{|l|}{ Horizontal } \\
\hline Average duration & 19 & 15 & 14.5 & 16.8 \\
\hline Maximum duration & 28 & 20 & 28 & 23 \\
\hline Minimum duration & 10 & 8 & 5 & 7 \\
\hline Variability of duration & 0.37 & 0.34 & 0.64 & 0.37 \\
\hline Expansions:contractions ${ }^{\mathrm{a}}$ & 0.65 & 1.23 & 0.65 & 1.23 \\
\hline Proportion $^{\mathrm{b}}$ & 0.57 & 0.40 & 0.43 & 0.60 \\
\hline \multicolumn{5}{|l|}{ Vertical } \\
\hline Average amplitude & $-22.22 \%$ & $-10.15 \%$ & $10.34 \%$ & $27.51 \%$ \\
\hline Variability of amplitude & 0.45 & 0.19 & 0.25 & 0.56 \\
\hline Steepness & $-1.17 \%$ & $-0.68 \%$ & $0.71 \%$ & $1.64 \%$ \\
\hline Volatility & $1.93 \%$ & $1.34 \%$ & $1.21 \%$ & $2.08 \%$ \\
\hline Proportion $^{\mathrm{c}}$ & 0.50 & 0 & 0 & 0.50 \\
\hline
\end{tabular}

Average duration of an expansion relative to preceding contraction

Proportion of time spent in either phase

Proportion of phases with amplitude greater than $20 \%$ 
Table 8:

Classical cycle features of foreign (US) interest rates

\begin{tabular}{|c|c|c|c|c|c|c|}
\hline \multirow[t]{2}{*}{ Characteristic } & \multicolumn{3}{|c|}{ Contraction } & \multicolumn{3}{|c|}{ Expansion } \\
\hline & $\begin{array}{c}\text { Foreign } \\
\text { Interest } \\
\text { Rate } \\
\text { Differential } \\
\end{array}$ & $\begin{array}{c}\text { USA } \\
\text { Federal } \\
\text { Funds } \\
\text { Rate } \\
\end{array}$ & $\begin{array}{c}\text { USA } \\
10 \text { year } \\
\text { Govt } \\
\text { Bond Yield } \\
\end{array}$ & $\begin{array}{c}\text { Foreign } \\
\text { Interest } \\
\text { Rate } \\
\text { Differential } \\
\end{array}$ & $\begin{array}{c}\text { USA } \\
\text { Federal } \\
\text { Funds } \\
\text { Rate }\end{array}$ & $\begin{array}{c}\text { USA } \\
10 \text { year } \\
\text { Govt } \\
\text { Bond Yield }\end{array}$ \\
\hline \multicolumn{7}{|l|}{ Horizontal } \\
\hline Average duration & 24.3 & 28.8 & 27.2 & 28 & 22.8 & 12.2 \\
\hline Maximum duration & 32 & 45 & 41 & 51 & 29 & 15 \\
\hline Minimum duration & 15 & 7 & 14 & 5 & 16 & 9 \\
\hline Variability of duration & 0.29 & 0.53 & 0.38 & 0.58 & 0.25 & 0.22 \\
\hline Expansions:contractions ${ }^{\mathrm{a}}$ & 0.76 & 1.31 & 0.65 & 0.76 & 1.31 & 0.65 \\
\hline Proportion $^{\mathrm{b}}$ & 0.39 & 0.56 & 0.69 & 0.61 & 0.44 & 0.31 \\
\hline \multicolumn{7}{|l|}{ Vertical } \\
\hline Average amplitude & -737 bp & $-357 b p$ & $-265 b p$ & 786 bp & $235 \mathrm{bp}$ & $190 \mathrm{bp}$ \\
\hline Variability of amplitude & 0.55 & 0.76 & 0.26 & 0.24 & 0.58 & 0.34 \\
\hline Steepness & $-30 b p$ & $-12 b p$ & $-10 b p$ & $28 \mathrm{bp}$ & $10 \mathrm{bp}$ & $16 \mathrm{bp}$ \\
\hline Volatility & $35 \mathrm{bp}$ & $15 \mathrm{bp}$ & $19 \mathrm{bp}$ & $36 \mathrm{bp}$ & $16 \mathrm{bp}$ & $23 \mathrm{bp}$ \\
\hline Proportion $^{\mathrm{c}}$ & 0.67 & 0.5 & 0 & 0.75 & 0 & 0 \\
\hline
\end{tabular}

Average duration of an expansion relative to preceding contraction

Proportion of time spent in either phase

Proportion of phases with amplitude greater than 500 basis points 
Table 9:

Twelve-month growth rate cycle features of monetary variables

\begin{tabular}{|c|c|c|c|c|}
\hline \multirow[t]{2}{*}{ Characteristic } & \multicolumn{2}{|c|}{ Contraction } & \multicolumn{2}{|c|}{ Expansion } \\
\hline & Real M1 & Real M3 & Real M1 & Real M3 \\
\hline \multicolumn{5}{|l|}{ Horizontal } \\
\hline Average duration & 13.6 & 13.4 & 15.3 & 14.1 \\
\hline Maximum duration & 28 & 27 & 29 & 26 \\
\hline Minimum duration & 9 & 7 & 6 & 7 \\
\hline Variability of duration & 0.47 & 0.54 & 0.45 & 0.44 \\
\hline Expansions:contractions ${ }^{\mathrm{a}}$ & 1.08 & 1.36 & 1.08 & 1.36 \\
\hline Proportion $^{\mathrm{b}}$ & 0.44 & 0.49 & 0.56 & 0.51 \\
\hline \multicolumn{5}{|l|}{ Vertical } \\
\hline Average amplitude & $-24.58 \mathrm{pp}$ & $-11.15 \mathrm{pp}$ & $27.42 \mathrm{pp}$ & $12.60 \mathrm{pp}$ \\
\hline Variability of amplitude & 0.26 & 0.13 & 0.35 & 0.42 \\
\hline Steepness & $-1.81 \mathrm{pp}$ & $-0.83 p p$ & $1.80 \mathrm{pp}$ & $0.89 \mathrm{pp}$ \\
\hline Volatility & $3.20 \mathrm{pp}$ & $1.48 \mathrm{pp}$ & $3.47 \mathrm{pp}$ & $1.54 \mathrm{pp}$ \\
\hline Proportion $^{\mathrm{c}}$ & 0.71 & 0 & 1.0 & 0.14 \\
\hline $\begin{array}{l}\text { Average duration of } \\
\text { Proportion of time sp } \\
\text { Proportion of phases }\end{array}$ & $\begin{array}{l}\text { asion relative } \\
\text { ither phase } \\
\text { aplitude greate }\end{array}$ & $\begin{array}{l}\text { oreceding con } \\
\text { an } 20 \text { percen }\end{array}$ & on & \\
\hline
\end{tabular}


Table 10:

Twelve-month growth rate cycle features of local stock market indices

\begin{tabular}{|c|c|c|c|c|c|c|}
\hline \multirow[t]{2}{*}{ Characteristic } & \multicolumn{3}{|c|}{ Contraction } & \multicolumn{3}{|c|}{ Expansion } \\
\hline & $\begin{array}{c}\text { JSE } \\
\text { All } \\
\text { Share } \\
\text { Index } \\
\end{array}$ & $\begin{array}{c}\text { JSE } \\
\text { Financial \& } \\
\text { Industrial } \\
\text { Index } \\
\end{array}$ & $\begin{array}{c}\text { JSE } \\
\text { Resources } \\
\text { Index }\end{array}$ & $\begin{array}{l}\text { JSE Share } \\
\text { Price Index }\end{array}$ & $\begin{array}{c}\text { JSE } \\
\text { Financial \& } \\
\text { Industrial } \\
\text { Index }\end{array}$ & $\begin{array}{c}\text { JSE } \\
\text { Resources } \\
\text { Index }\end{array}$ \\
\hline \multicolumn{7}{|l|}{ Horizontal } \\
\hline Average duration & 15.4 & 13.7 & 14 & 13.6 & 11.5 & 14.9 \\
\hline Minimum duration & 10 & 5 & 9 & 6 & 7 & 8 \\
\hline Variability of duration & 0.44 & 0.34 & 0.25 & 0.33 & 0.25 & 0.37 \\
\hline Expansions:contractions ${ }^{\mathrm{a}}$ & 1.00 & 1.11 & 1.13 & 1.00 & 1.11 & 1.13 \\
\hline Variability of amplitude & 0.27 & 0.24 & 0.22 & 0.34 & 0.41 & 0.34 \\
\hline Steepness & -3.93 pp & $-3.47 \mathrm{pp}$ & $-5.60 \mathrm{pp}$ & $4.27 \mathrm{pp}$ & $4.37 \mathrm{pp}$ & $4.97 \mathrm{pp}$ \\
\hline Volatility & $7.43 \mathrm{pp}$ & $5.40 \mathrm{pp}$ & $7.37 \mathrm{pp}$ & $8.11 \mathrm{pp}$ & $6.02 \mathrm{pp}$ & $7.99 \mathrm{pp}$ \\
\hline Proportion $^{\mathrm{c}}$ & 1.0 & 1.0 & 1.0 & 1.0 & 1.0 & 1.0 \\
\hline $\begin{array}{l}\text { Average duration of } \\
\text { Proportion of time sp } \\
\text { Proportion of phases }\end{array}$ & $\begin{array}{l}\text { on relative to } \\
\text { er phase } \\
\text { itude greater } t\end{array}$ & $\begin{array}{l}\text { eceding contrac } \\
\text { n } 20 \text { percentag }\end{array}$ & & & & \\
\hline
\end{tabular}


Table 11:

Twelve-month growth rate cycle features of international stock market indices

\begin{tabular}{|c|c|c|c|c|c|c|}
\hline \multirow[t]{2}{*}{ Characteristic } & \multicolumn{3}{|c|}{ Contraction } & \multicolumn{3}{|c|}{ Expansion } \\
\hline & $\begin{array}{l}\text { S\&P } 500 \\
\text { Share } \\
\text { Index }\end{array}$ & $\begin{array}{c}\text { MSCI } \\
\text { Emerging } \\
\text { Market } \\
\text { Share Index } \\
\end{array}$ & $\begin{array}{c}\text { JP Morgan } \\
\text { Emerging } \\
\text { Market } \\
\text { Bond Index } \\
\end{array}$ & $\begin{array}{l}\text { S\&P } 500 \\
\text { Share } \\
\text { Index }\end{array}$ & $\begin{array}{c}\text { MSCI } \\
\text { Emerging } \\
\text { Market } \\
\text { Share Index } \\
\end{array}$ & $\begin{array}{c}\text { JP Morgan } \\
\text { Emerging } \\
\text { Market } \\
\text { Bond Index }\end{array}$ \\
\hline \multicolumn{7}{|l|}{ Horizontal } \\
\hline Minimum duration & 6 & 11 & 11 & 6 & 10 & 7 \\
\hline Variability of duration & 0.59 & 0.25 & 0.61 & 0.49 & 0.27 & 0.42 \\
\hline Expansions:contractions ${ }^{\mathrm{a}}$ & 1.27 & 0.91 & 1.61 & 1.27 & 0.91 & 1.61 \\
\hline Variability of amplitude & 0.55 & 0.30 & 0.53 & 0.53 & 0.37 & 0.61 \\
\hline Steepness & $-2.64 \mathrm{pp}$ & $-4.69 \mathrm{pp}$ & $-4.17 \mathrm{pp}$ & $2.98 \mathrm{pp}$ & $5.35 \mathrm{pp}$ & $4.18 \mathrm{pp}$ \\
\hline Volatility & $4.17 \mathrm{pp}$ & $7.26 \mathrm{pp}$ & $5.97 \mathrm{pp}$ & $4.72 \mathrm{pp}$ & $7.70 \mathrm{pp}$ & $5.90 \mathrm{pp}$ \\
\hline Proportion $^{\mathrm{c}}$ & 0.67 & 1.0 & 1.0 & 0.71 & 1.0 & 0.8 \\
\hline $\begin{array}{l}\text { Average duration of } \\
\text { Proportion of time sp } \\
\text { Proportion of phases }\end{array}$ & $\begin{array}{l}\text { on relative to } \\
\text { er phase } \\
\text { itude greater }\end{array}$ & $\begin{array}{l}\text { eceding contrac } \\
\text { n } 20 \text { percentage }\end{array}$ & pints & & & \\
\hline
\end{tabular}


Table 12:

Twelve-month growth rate cycle features of foreign exchange rates

\begin{tabular}{|c|c|c|c|c|c|c|}
\hline \multirow[t]{2}{*}{ Characteristic } & \multicolumn{3}{|c|}{ Contraction } & \multicolumn{3}{|c|}{ Expansion } \\
\hline & $\begin{array}{c}\text { Real } \\
\text { Effective } \\
\text { Exchange } \\
\text { Rate }\end{array}$ & $\begin{array}{c}\text { Real } \\
\text { R / Dollar } \\
\text { Exchange } \\
\text { Rate }\end{array}$ & $\begin{array}{l}\text { Nominal } \\
\mathrm{R} / \text { Dollar } \\
\text { Exchange } \\
\text { Rate } \\
\end{array}$ & $\begin{array}{l}\text { Real } \\
\text { Effective } \\
\text { Exchange } \\
\text { Rate } \\
\end{array}$ & $\begin{array}{l}\text { Real } \\
\mathrm{R} / \text { Dollar } \\
\text { Exchange } \\
\quad \text { Rate } \\
\end{array}$ & $\begin{array}{l}\text { Nominal } \\
\mathrm{R} / \text { Dollar } \\
\text { Exchange } \\
\text { Rate } \\
\end{array}$ \\
\hline \multicolumn{7}{|l|}{ Horizontal } \\
\hline Average duration & 15.8 & 13.6 & 14.1 & 12.6 & 17.5 & 18 \\
\hline Minimum duration & 6 & 5 & 5 & 9 & 11 & 11 \\
\hline Variability of duration & 0.55 & 0.38 & 0.41 & 0.31 & 0.33 & 0.33 \\
\hline Expansions:contractions ${ }^{\mathrm{a}}$ & 0.97 & 1.60 & 1.65 & 0.97 & 1.60 & 1.65 \\
\hline Variability of amplitude & 0.53 & 0.60 & 0.58 & 0.70 & 0.31 & 0.31 \\
\hline Steepness & $-1.37 \mathrm{pp}$ & $-2.66 \mathrm{pp}$ & $-2.54 \mathrm{pp}$ & $2.05 \mathrm{pp}$ & $1.87 \mathrm{pp}$ & $1.71 \mathrm{pp}$ \\
\hline Volatility & $2.28 \mathrm{pp}$ & $3.74 \mathrm{pp}$ & $3.75 \mathrm{pp}$ & $3.30 \mathrm{pp}$ & $2.50 \mathrm{pp}$ & $2.30 \mathrm{pp}$ \\
\hline Proportion $^{\mathrm{c}}$ & 0.4 & 0.86 & 0.86 & 0.6 & 0.83 & 0.83 \\
\hline $\begin{array}{l}\text { Average duration of } \\
\text { Proportion of time sp } \\
\text { Proportion of phases }\end{array}$ & $\begin{array}{l}\text { on relative to } \\
\text { er phase } \\
\text { itude greater } t\end{array}$ & $\begin{array}{l}\text { ceding contra } \\
20 \text { percentag }\end{array}$ & & & & \\
\hline
\end{tabular}


Table 13:

Summary of classical cycle features for contraction phases relative to expansion phases (1)

\begin{tabular}{|c|c|c|c|c|c|c|c|c|}
\hline \multirow[t]{2}{*}{ Financial variable } & \multicolumn{4}{|c|}{ Horizontal features } & \multicolumn{4}{|c|}{ Vertical features } \\
\hline & $\begin{array}{c}\text { Average } \\
\text { Contraction } \\
\text { Duration } \\
\text { vs } \\
\text { Expansions } \\
\end{array}$ & $\begin{array}{c}\text { Supported } \\
\text { by } \\
\text { other } \\
\text { stats? }\end{array}$ & $\begin{array}{c}\text { Variability } \\
\text { of } \\
\text { Successive } \\
\text { Contraction } \\
\text { Durations }\end{array}$ & $\begin{array}{c}\text { Variability } \\
\text { of } \\
\text { Successive } \\
\text { Expansion } \\
\text { Durations }\end{array}$ & $\begin{array}{c}\text { Average } \\
\text { Contraction } \\
\text { Amplitude } \\
\text { vs } \\
\text { Expansions }\end{array}$ & $\begin{array}{c}\text { Average } \\
\text { Contraction } \\
\text { Steepness } \\
\text { Vs } \\
\text { Expansions } \\
\end{array}$ & $\begin{array}{c}\text { Variability } \\
\text { of } \\
\text { Successive } \\
\text { Contraction } \\
\text { Amplitudes }\end{array}$ & $\begin{array}{c}\text { Variability } \\
\text { of } \\
\text { Successive } \\
\text { Expansion } \\
\text { Amplitudes }\end{array}$ \\
\hline Real M1 & Shorter & Yes & 0.28 & 0.48 & Lower & Steeper & 0.25 & 0.53 \\
\hline Real M3 & Shorter & Yes & 0.94 & 0.60 & Lower & Steeper & 0.65 & 0.38 \\
\hline JSE All Share Index & Shorter & Yes & 0.37 & 0.51 & Lower & Steeper & 0.57 & 0.37 \\
\hline JSE Fin and Ind Index & Shorter & Yes & 0.57 & 0.48 & Lower & Steeper & 0.64 & 0.41 \\
\hline JSE Resources Index & Shorter & Yes & 0.62 & 0.48 & Lower & Steeper & 0.30 & 0.56 \\
\hline MSCI Emerging Market & Shorter & Yes & 0.58 & 0.36 & Lower & Steeper & 0.42 & 0.51 \\
\hline JSE ALSI Divid Yield & $\begin{array}{l}\text { Slightly } \\
\text { longer }\end{array}$ & Yes & 0.52 & 0.55 & Lower & Similar & 0.35 & 0.47 \\
\hline JSE ALSI P:E Ratio & Similar & Uncertain & 0.98 & 0.71 & $\begin{array}{c}\text { Slightly } \\
\text { lower }\end{array}$ & Similar & 0.46 & 0.51 \\
\hline Real Effective Rand ${ }^{\dagger}$ & Longer & Yes & 0.37 & 0.64 & Higher & Steeper & 0.45 & 0.25 \\
\hline Real Rand-Dollar ${ }^{\dagger}$ & Shorter & Yes & 0.34 & 0.37 & Lower & Shallower & 0.19 & 0.56 \\
\hline
\end{tabular}


Table 14:

Summary of classical cycle features for contraction phases relative to expansion phases (2)

\begin{tabular}{|c|c|c|c|c|c|c|c|c|}
\hline \multirow{2}{*}{ Financial variable } & \multicolumn{4}{|c|}{ Horizontal features } & \multicolumn{4}{|c|}{ Vertical features } \\
\hline & $\begin{array}{c}\text { Average } \\
\text { Contraction } \\
\text { Duration } \\
\text { vs } \\
\text { Expansions }\end{array}$ & $\begin{array}{c}\text { Supported } \\
\text { by } \\
\text { other } \\
\text { stats? }\end{array}$ & $\begin{array}{c}\text { Variability } \\
\text { of } \\
\text { Successive } \\
\text { Contraction } \\
\text { Durations }\end{array}$ & $\begin{array}{c}\text { Variability } \\
\text { of } \\
\text { Successive } \\
\text { Expansion } \\
\text { Durations }\end{array}$ & $\begin{array}{c}\text { Average } \\
\text { Contraction } \\
\text { Amplitude } \\
\text { vs } \\
\text { Expansions }\end{array}$ & $\begin{array}{c}\text { Average } \\
\text { Contraction } \\
\text { Steepness } \\
\text { Vs } \\
\text { Expansions }\end{array}$ & $\begin{array}{c}\text { Variability } \\
\text { of } \\
\text { Successive } \\
\text { Contraction } \\
\text { Amplitudes }\end{array}$ & $\begin{array}{c}\text { Variability } \\
\text { of } \\
\text { Successive } \\
\text { Expansion } \\
\text { Amplitudes }\end{array}$ \\
\hline 3-month Treasury bill yield & $\begin{array}{l}\text { Slightly } \\
\text { shorter }\end{array}$ & Yes & 0.82 & 0.57 & Higher & Steeper & 0.60 & 0.56 \\
\hline 12-month NCD interest rate & Longer & Yes & 0.65 & 0.71 & Higher & Shallower & 0.58 & 0.54 \\
\hline 10-year govt bond yield & Longer & Yes & 0.57 & 0.83 & Higher & Shallower & 0.48 & 0.48 \\
\hline Real 3-m T-Bill yield & Longer & Yes & 0.73 & 0.52 & Lower & Shallower & 0.49 & 0.51 \\
\hline Real 12-m NCD interest rate & Shorter & Yes & 0.56 & 0.44 & Lower & Similar & 0.39 & 0.54 \\
\hline Real 10-year govt bond yld & Similar & Yes & 0.37 & 0.63 & Lower & Shallower & 0.47 & 0.48 \\
\hline Yield curve & Longer & Uncertain & 0.68 & 0.59 & Higher & Similar & 0.50 & 0.38 \\
\hline Reverse yield gap & Longer & Uncertain & 0.54 & 0.69 & Higher & Similar & 0.37 & 0.40 \\
\hline Foreign int rate differential & Shorter & Yes & 0.29 & 0.58 & Lower & Similar & 0.55 & 0.24 \\
\hline US Federal Funds rate & Longer & Uncertain & 0.53 & 0.25 & Higher & Similar & 0.76 & 0.58 \\
\hline US 10-year govt bond yield & Longer & Yes & 0.38 & 0.22 & Higher & Shallower & 0.26 & 0.34 \\
\hline
\end{tabular}


Table 15:

Summary of growth rate cycle features for contraction phases relative to expansion phases

\begin{tabular}{|c|c|c|c|c|c|c|c|c|}
\hline \multirow[t]{2}{*}{ Financial variable } & \multicolumn{4}{|c|}{ Horizontal features } & \multicolumn{4}{|c|}{ Vertical features } \\
\hline & $\begin{array}{c}\text { Average } \\
\text { Contraction } \\
\text { Duration } \\
\text { vs } \\
\text { Expansions }\end{array}$ & $\begin{array}{c}\text { Supported } \\
\text { by } \\
\text { other } \\
\text { stats? }\end{array}$ & $\begin{array}{c}\text { Variability } \\
\text { of } \\
\text { Successive } \\
\text { Contraction } \\
\text { Durations }\end{array}$ & $\begin{array}{l}\text { Variability } \\
\text { of } \\
\text { Successive } \\
\text { Expansion } \\
\text { Durations }\end{array}$ & $\begin{array}{c}\text { Average } \\
\text { Contraction } \\
\text { Amplitude } \\
\text { vs } \\
\text { Expansions }\end{array}$ & $\begin{array}{c}\text { Average } \\
\text { Contraction } \\
\text { Steepness } \\
\text { Vs } \\
\text { Expansions }\end{array}$ & $\begin{array}{l}\text { Variability } \\
\text { of } \\
\text { Successive } \\
\text { Contraction } \\
\text { Amplitudes }\end{array}$ & $\begin{array}{l}\text { Variability } \\
\text { of } \\
\text { Successive } \\
\text { Expansion } \\
\text { Amplitudes }\end{array}$ \\
\hline Real M1 & Shorter & Yes & 0.47 & 0.45 & Lower & Similar & 0.26 & 0.35 \\
\hline Real M3 & $\begin{array}{l}\text { Slightly } \\
\text { shorter }\end{array}$ & Uncertain & 0.54 & 0.44 & Lower & Similar & 0.13 & 0.42 \\
\hline JSE All Share Index & Longer & Uncertain & 0.44 & 0.33 & Lower & Shallower & 0.27 & 0.34 \\
\hline JSE Fin and Ind Index & Longer & Yes & 0.34 & 0.25 & Lower & Shallower & 0.24 & 0.41 \\
\hline JSE Resources Index & Similar & Uncertain & 0.25 & 0.37 & Higher & Steeper & 0.22 & 0.34 \\
\hline S\&P 500 Share Index & Similar & No & 0.59 & 0.49 & Lower & Similar & 0.55 & 0.53 \\
\hline MSCI Emerging Share & Longer & Yes & 0.25 & 0.27 & Similar & Shallower & 0.30 & 0.37 \\
\hline JP Morgan Emerging Bond & Similar & Uncertain & 0.61 & 0.42 & Lower & Similar & 0.53 & 0.61 \\
\hline Real Effective Rand & Longer & Uncertain & 0.55 & 0.31 & Lower & Shallower & 0.53 & 0.70 \\
\hline Real Rand-Dollar & Shorter & Uncertain & 0.38 & 0.33 & Higher & Steeper & 0.60 & 0.31 \\
\hline Nominal Rand-Dollar & Shorter & Uncertain & 0.41 & 0.33 & Higher & Steeper & 0.58 & 0.31 \\
\hline
\end{tabular}




\section{PART II FINANCIAL VARIABLES AS LEADING INDICATORS}

The previous sections have highlighted the salient features of historical behaviour in South African financial variables within the turning point cycle framework. While the framework is traditionally applied to business cycles analysis, its application to financial time series enables a comparison of turning points in financial variables with turning points in the business cycle. Part II attempts such comparisons with the purpose of identifying a set of financial variables suitable for forecasting peaks and/or troughs in business cycles.

In the spirit of the Burns and Mitchell approach to cycle analysis, the leading indicator study presented here does not rely on particular economic theories in its choice of variables to evaluate as potential leading indicators ${ }^{10}$. Broadly speaking, though, the expanding literature on interaction between the financial and real sectors ${ }^{11}$ underscores the necessity of such a leading indicator analysis. In modern economies, agents use financial markets to transform and diversify future risks. Turning points in financial variables, reflecting adjustments in agents' expectations of the future, could therefore assist in generating forecasts of turning points in the real economy.

Official leading indicators of the business cycle in industrialised and emerging countries already include several financial variables. The composite leading index for the USA (compiled by the Conference Board 2004) include a share price indicator, a money supply measure as well as an interest rate spread, while the OECD's composite leading indicators for the USA, UK and Germany include a share price indicator (for the trio) and a short-term interest rate measure (for the US and UK) (OECD 2005). In South Africa, the composite leading indicator contains, among others, the M1 money supply, a JSE share price index and an interest rate spread (Venter and Pretorius 2004: 69). The aim of the subsequent analyses is to evaluate a broad range of financial variables as potential leading indicators via application of both established descriptive techniques and new statistical tests.

\footnotetext{
${ }^{10}$ In their survey of the success of asset prices in forecasting output and inflation, Stock and Watson (2003: 801) find that those financial variables with the strongest theoretical support as forecasting instruments frequently perform surprisingly poorly in empirical evaluations.

${ }^{11}$ See Cochrane (2005) for a recent survey.
} 


\section{CHAPTER 3 FRAMEWORK FOR LEADING INDICATOR EVALUATION}

\subsection{LEADING INDICATOR CONCEPTS}

Burns and Mitchell (1938: 1) originally defined a leading indicator as "a fairly consistent indicator of cyclical movements in general business". This concept is embedded in their turning point approach to business cycle analysis, as "consistent" here refers to the capacity of turning points in an indicator series to lead business cycle turning points with a fairly stable lead interval (Granger 1989: 173). Geoffrey Moore - who popularised the use of leading indicators and developed the composite leading indicator concept - also worked in this tradition (Moore 1950; Achuthan and Banerji 2004).

This traditional approach embodies an implicitly non-linear view that empirical relations among economic variables shift at business cycle turning points (Auerbach 1982; Granger 1989). Consequently, the traditional approach evades the use of macro-econometric specifications in the evaluation of leading indicators, focusing instead on extensive descriptive analyses of lead intervals, supported by fairly rudimentary statistical calculations (see Moore 1950). However, as early as the 1940s this approach to turning point forecasting met with opposition from an economics profession questioning the a-theoretical, model-free nature of the Burns-MitchellMoore analysis. The "measurement without theory" attack by Tjalling Koopmans (1947) on the work of Burns and Mitchell (1946) served as a precursor for the steady move towards formal econometric modelling in economics. The subsequent work of Koopmans, Marshak, Frisch and Tinbergen firmly established econometric modelling as the empirical toolkit of the macroeconomist (Pagan 2003).

The rise of econometric modelling had a concomitant impact on the evaluation of potential leading indicators. Two approaches to turning point forecasting emerged in the econometric literature. The first approach is less concerned with turning point forecasts per se, but emphasise that turning points are "by-products" (Del Negro 2001: 5) of value forecasts generated by macro-econometric models. The development of a range of theory- and data-driven econometric models (see Pagan 
2003) has resulted in the identification of reasonably successful "leading indicators" within this context. These "leading indicators" are quite different from the original concept as goodness-of-fit measures replace stability of lead intervals as the overriding criterion for acceptance as leading indicator. Moreover, while econometric forecasting models perform reasonably well within particular business cycle phases (also called business cycle regimes) these specifications frequently suffer large forecasts errors around business cycle turning points (Achuthan and Banerji 2004; Diebold and Rudebusch 1999).

However, new methods in the value forecasting tradition evolved to address these forecasting deficiencies. In 1989 Hamilton made a seminal contribution through the regime-switching model that incorporates separate data generating processes for business cycle expansions and contractions respectively. Rapid growth in the nonlinear modelling literature testifies to the need for such specifications, although the forecasting performance of regime-switching models still lags linear statistical models $^{12}$ (Clements and Hendry 1999: 283-285).

These forecast discrepancies at turning points highlight the potential usefulness of an explicit modelling of business cycle regimes or turning points. In response to this, the second approach to econometric forecasting of turning points emerged. This involves the use of probit models in directly modelling probabilities of business cycle regimes, particularly recessions (see Estrella and Mishkin 1998; Del Negro 2001). The use of discrete (instead of continuous) dependent variables resulted in improved forecasting accuracy with regard to business cycle recessions (Del Negro 2001).

However, even in this context, the evaluation of leading indicators continues to be based on goodness-of-fit measures (see Moolman (2003) for the use of the "pseudo

\footnotetext{
${ }^{12}$ Alternative non-linear specifications, such as the neural network, have been proposed to deal with the forecasting failures of the more conventional non-linear models. In a recent contribution, Jagric and Strasek (2005) claim that their neural network model of the Slovenian economy is able to forecast Slovenian industrial production accurately - even in the presence of business cycle turning points. While their model appears to have merit in general value forecasting, their claim that the forecasting horizon relative to business cycle turning points is stable is less plausible (as they do not test for this explicitly).
} 


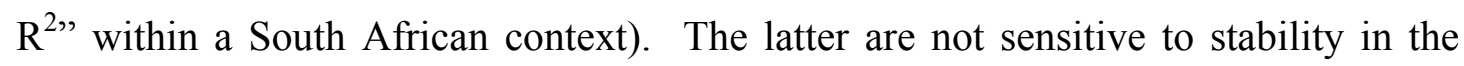
lead-time between turning points in the "leading indicator" and turning points in the business cycle. Without robust lead-times the ability of such models to forecast turning points might be severely compromised. This shortcoming of the modern econometric tradition is a negative reason for considering the earlier method that focussed explicitly on turning points. The Economic Cycle Research Institute in New York, which has been faithfully applying the original techniques pioneered by Moore, has accurately predicted the past two recessions in the United States - a feat not paralleled by any of the large forecasting houses that use conventional econometric models to forecast turning points (Achuthan and Banerji 2004; also see Del Negro (2001) and Filardo (1999) on the success of econometric turning point forecasts). Consequently, the traditional model-free approach followed by Moore (and Burns and Mitchell) potentially represents an important complement to econometric models which have also seen improvements in turning points forecasts ${ }^{13}$.

The following sections discuss the model-free approach as applied to the evaluation of financial variables as leading indicators of the South African business cycle. The discussion will incorporate recent statistical contributions by Harding and Pagan (2001; 2002) and Banerji (1999a) that have helped to address some of the deficiencies that plagued the original leading indicator evaluation attempts by Moore and others.

\subsection{OBJECTIVE EVALUATION CRITERIA}

In the previous section a case was made for considering a model-free approach to forecasting business cycle turning points. Even with model-free forecasting it is necessary to define criteria for separating good from poor forecasting strategies. This section introduces such a set of criteria with which to evaluate potential leading indicators.

\footnotetext{
${ }^{13}$ The multi-step forecasting model of Muellbauer and Nunziata (2004) is an exception to the otherwise poor ability of econometric models to forecast business cycle turning points. This model outperforms the Survey of Professional Forecasters in identifying turning points in the growth rate of US real GDP per capita in real time (prior to data revisions). In particular, the model accurately identifies the 2001 recession in the United States - an accomplishment not shared by many econometric models in the US.
} 
Moore (1950) identifies two requirements for a time series to qualify as an acceptable indicator of cycles in real economic activity:

(i) Conformity between the proposed indicator and the business cycle.

(ii) Stability in the time interval between turning points in real economic activity and turning points in the potential indicator.

These requirements form the core of an expanded set of characteristics that Moore identified for useful leading indicators; they are the results of his effort to reduce, if not eliminate, turning point forecasting errors by leading indicators. Moore's criteria also highlights the difference between the two traditions in business cycle forecasting, with the linear econometric models focussing mainly on Moore's first criterion, while the traditional approach place considerable emphasis on the second. In South Africa, business cycle researchers at the Reserve Bank have also emphasised that historical conformity and the timing relation with the business cycle are the central evaluation criteria for leading indicators (see Venter and Pretorius (2004) and Van der Walt (1983)).

Apart from conformity and stability of lead intervals, the smoothness of the series and the timeliness of the data are also important (see Moore, 1950: 21 and Van der Walt, 1983). While availability and timeliness of South African financial data are not problematic, the smoothness of financial time series may raise questions. High levels of volatility in local and international financial markets may generate restrictive amounts of noise in series. However, tests for conformity (i.e. concordance tests) act as filters to eliminate those financial series that display an excessive amount of false signals concerning business cycle turning points. Nonetheless, the problem of noisiness (or false signals) is a deep one and intimately related to the problem of realtime identification of turning points. The restrictive impact of noise on forecast confidence may, however, be reduced if several leading indicators from a broad range of sectors are observed - an approach originally proposed by Burns and Mitchell and one adopted at the Reserve Bank. Hence, it is clear that the requirements of conformity to business cycles and time lead consistency remain the central criteria in the evaluation of leading indicators.

Given the above two evaluation criteria, the question of measuring how well a particular financial variable adheres to these requirements becomes important. 
Originally, Moore (1950) attempted a scrutiny of lead interval behaviour using detailed tabulations of descriptive statistics. The mere description of historical behaviour, however, does not offer sufficient evidence in favour of a particular leading indicator. Given a limited sample period, statistical inference is required to provide an objective assessment of the performance of a potential indicator. The need for statistical evaluation has been an important factor discouraging the use of the traditional approach to leading indicator analysis, as mentioned earlier. However, recent statistical developments in business cycle analysis by Harding and Pagan (2001; 2002) and Banerji (1999a) have placed the traditional approach on a more objective statistical basis, without losing the model-free character of the traditional framework.

The following two chapters will attend to statistical evaluation (via description and hypothesis testing) of the two main criteria for an acceptable leading indicator: business cycle conformity and stability of lead intervals. 


\section{CHAPTER 4 CO-MOVEMENT BETWEEN CYCLES IN FINANCIAL VARIABLES AND CYCLES IN REAL ACTIVITY}

\subsection{Statistical Methodology}

While it is relatively simple to assess the co-movement between two series using cross-correlations (see for example Andreou et al, 2000), this technique requires stationary time series. However, macroeconomic time series are commonly nonstationary due to the presence of stochastic trends. Such stochastically non-stationary series can be rendered stationary through differences, but only with a very considerable loss of information. In particular, the time series properties of first differences of a series differ from the properties of series in levels. Specifically, Bry and Boschan (1971: 13) illustrate the difference in the duration of cycle phases for series in first differences versus levels. Consequently, statistically significant correlation of a differenced series with some other stationary variable does not imply a statistically significant correlation between the series in levels and the other variable.

To avoid these statistical pitfalls, this study attempts an investigation of co-movement using the concordance statistic, which does not require stationary time series. A second advantage of the concordance index is that it is robust against single common shocks. In contrast, high correlation may be the result of a single shock common to two series that are otherwise independent (McDermott and Scott 2000: 18). The concordance statistic, on the other hand, does not suffer from sudden jumps in series as it is based on the constructed state variable series $\left\{s_{t}\right\}$ instead of the actual series $\left\{x_{t}\right\}$.

Formally, co-movement (or the degree of synchronisation of two series) is assessed by considering what proportion of time the two series are simultaneously in the same phase. Statistically, this amounts to testing whether $I=\operatorname{Pr}\left(S_{x t}=S_{y t}\right)$ is close to 1 , where $S_{x t}=1$ identifies an expansion in financial series $\left\{x_{t}\right\}$ and $S_{y t}=1$ identifies a business cycle upswing at time $t$. For a particular sample, the equivalent of $\operatorname{Pr}\left(S_{x t}=S_{y t}\right)$ is the so-called concordance index $(\hat{I})$ (Harding and Pagan 2003): 


$$
\begin{aligned}
& \hat{I}=\frac{1}{T}\left\{\#\left(s_{x t}=1, s_{y t}=1\right)+\#\left(s_{x t}=0, s_{y t}=0\right)\right\} \\
& \hat{I}=\frac{1}{T}\left\{\sum_{t=1}^{T} s_{x t} s_{y t}+\sum_{t=1}^{T}\left(1-s_{x t}\right)\left(1-s_{y t}\right)\right\}
\end{aligned}
$$

The index as defined above ranges from zero (perfect non-alignment) to one (perfect alignment), with 0.5 indicating independence. However, the concordance index can be re-scaled to lie in the range $[-1 ; 1]$ - thus enhancing its comparability with conventional correlation statistics ${ }^{14}$. To consider lagged co-movement, the series $\left\{x_{t}\right\}$ is replaced with $\left\{x_{t-m}\right\}$, an m-period lagged version of $\left\{x_{t}\right\}$.

The sample statistic $\hat{I}$ can now be used to test the statistical significance of the population statistic $I$. However, high or low values of $\hat{I}$ relative to 0.5 cannot be interpreted a priori as statistically significant. To see this, Harding and Pagan (2003: 11) propose rewriting (4.1.1) as:

$$
\hat{I}=1+2 \hat{\rho}_{S} \hat{\sigma}_{S x} \hat{\sigma}_{S y}+2 \hat{\mu}_{S x} \hat{\mu}_{S y}-\hat{\mu}_{S x}-\hat{\mu}_{S y}
$$

where

$$
\begin{array}{ll}
\hat{\rho}_{S} & \text { estimated correlation coefficient between states } S_{x t} \text { and } \\
& S_{y t} \\
\hat{\mu}_{S x} \text { and } \hat{\mu}_{S y} & \text { estimated mean of } S_{x t} \text { and } S_{y t} \text { respectively } \\
\hat{\sigma}_{S x} \text { and } \hat{\sigma}_{S y} & \text { estimated standard deviation of } S_{x t} \text { and } S_{y t} \text { respectively }
\end{array}
$$

If $\hat{\rho}_{S}=0$, that is, if the constructed state variables $S_{x t}$ and $S_{y t}$ are uncorrelated, $E(\hat{I})$ can only be 0.5 if $\hat{\mu}_{S x}=\hat{\mu}_{S y}=0.5$. If this is not the case, high or low values of $\hat{I}$ might be misleading. To overcome this problem, Artis et al (2004) suggest that the

\footnotetext{
${ }^{14}$ The mean-corrected concordance statistic $\left(\hat{I}^{*}\right.$ say $)$ is re-scaled $\left(\hat{I}^{* r}\right.$ say) to ensure that it falls within the range $[-1,1]$ using the following rules:

(i) If $\hat{I}^{*}<0$ then $\hat{I}^{* r}=\hat{I} * / \hat{\mu}_{S x}$

(ii) If $\hat{I}^{*}>0$ then $\hat{I}^{* r}=\hat{I}^{* /} /\left(1-\hat{\mu}_{S x}\right)$

where $\hat{\mu}_{S x}$ is the estimated mean of $\left\{S_{x t}\right\}$.
} 
mean-corrected values of $\hat{I}$ should be presented. A test statistic can then be constructed from the mean-corrected $\hat{I}$ by dividing it with its standard error under the null hypothesis of independence between $S_{x t}$ and $S_{y t}$. Unfortunately, this process requires substantial calculation effort.

Fortunately, Harding and Pagan (2003) propose an alternative that is much less demanding computationally. They show that $\hat{I}$ and $\hat{\rho}_{S}$ in (4.1.3) are related monotonically such that a statistical test for the significance of $\hat{\rho}_{S}$ can be used to assess the significance of $\hat{I}$.

To assess the significance of $\hat{\rho}_{S}$, consider the following linear regression:

$$
\hat{\sigma}_{S y}^{-1} S_{y t}=\eta+\hat{\rho}_{S} \hat{\sigma}_{S x}^{-1} S_{x t}+\varepsilon_{t}
$$

with

$$
\begin{array}{ll}
\eta & \text { a constant } \\
\varepsilon_{t} & \text { an independent and identically distributed error term }
\end{array}
$$

However, under the null hypothesis that $\hat{\rho}_{S}=0$, the error term $\varepsilon_{t}$ inherits the serial correlation properties of $S_{y t}$ - which risks conditional heteroscedasticity (Harding and Pagan, 2003). This may result in incorrect inferences regarding the significance of $\hat{\rho}_{S}$. But this problem can be addressed by testing the significance of OLS estimates for the parameters with heteroscedasticity and autocorrelation consistent (HAC) standard errors ${ }^{15}$. The method proposed by Newey and West (1987) is used to obtain the HAC estimates using Bartlett weights and an automatic bandwidth selection procedure. The robust $t$-ratios are then evaluated to determine the statistical significance of $\hat{I}^{16}$.

\footnotetext{
15 The $\mathrm{R}$ statistical language is used to perform the regressions ( $\mathrm{R}$ Foundation for Statistical Computing, 2005).

${ }^{16}$ It is important to note that, for a particular variable, either all or no lags are statistically significant, as p-values for tests of different lags are very similar (they differ only at the third or fourth decimal, e.g. 0.0877 and 0.0884 ). For example, the test for a lag of one takes the sample period (of the potential
} 
After statistical significance has been established, the lag range is identified for which the absolute value of the concordance statistic is maximised. High concordance with opposite signs at both high and low lags should be interpreted with caution. The high lag statistic may be measuring concordance with the next phase of the business cycle. In such cases, the lower lag range is given preference where the average phase durations in the real series are shorter than the higher lag mentioned above.

\subsection{Chronologies of South African Cycles $^{17}$ IN Real Economic ACTIVITY}

In subsequent analyses, four different cycles are used to represent the South African cycle of real economic activity: the SARB official business cycle, the GDP twelvemonth growth rate cycle, as well as the classical and twelve-month growth rate cycles of industrial production. Appendix $\mathrm{C}$ reports the chronologies of turning points in these cycles. The SARB official business cycle dates are obtained from the SARB Quarterly Bulletin (SARB 2005). The other three cycles are dated by employing the same methodology described in Part $I$ for the dating of cycles in financial variables. For the GDP growth rate the Bry-Boschan window width of two quarters is used (this corresponds with the assumptions in Du Plessis (2004)).

\subsection{Concordance of Classical Cycles in Financial Variables and CyCLES IN REAL ECONOMIC ACTIVITY}

This section investigates co-movement (through the mean-corrected concordance statistic) of cycles in financial variables with the different cycles in real economic activity, as mentioned in the previous section. Tables 22 to 29 report the concordance statistics of cycles in financial variables for different lead months relative to cycles in

\footnotetext{
leading indicator) used in the test of a zero lag and adjusts the period by shifting it one month forward. Therefore, the sample period for the test of a one-month lag differs only marginally from the sample period for the test of a zero-month lag. Test statistics based on these two sample periods will, therefore, also differ only marginally.

${ }^{17}$ See section 1.1 for a taxonomy of the different cycle concepts.
} 
real economic activity. As each table contains a large amount of information, tables are presented in Appendix D to ensure a neat presentation of the results.

Table 22 shows that the M3 monetary aggregate exhibits statistically significant comovement with the official SARB business cycle as well as with the classical and growth rate cycles of industrial production. Less convincing evidence is found for the M1 monetary aggregate - which leads only the industrial production growth rate cycle at a significant level.

Table 23 reports that the classical cycle of the nominal three-month interest rate has highly significant and strong co-movement with the official SARB cycle. The same is true for the classical cycle of the twelve-month NCD rate, which, in addition, also exhibits significant concordance with the growth rate cycle of GDP.

The real form (see Table 24) of the three-month rate corresponds with both the SARB official cycle and the growth rate cycle in industrial production at a statistically significant level. Additionally, evidence of significant concordance is found between the real ten-year long-term interest rate and the SARB cycle.

As far as classical cycles in share price indices are concerned, it appears that the JSE Resources Index is the only index to exhibit significant co-movement with classical cycles in GDP and industrial production (see Table 25). Table 26 further elucidate the difficulties encountered when using stock market variables as leading indicators. Neither the All Share dividend yield nor the All Share price-earnings ratio exhibits significant concordance with real activity. As far as spreads are concerned (see Table 27), the classical cycle in the yield curve shows significant concordance with the official SARB cycle, with no supporting evidence for the reverse yield gap.

Table 28 illustrates the absence of significant concordance between classical cycles in either of the real effective exchange rate or real rand-dollar bilateral exchange rate on the one hand and classical or growth rate cycles in real activity on the other. Finally, Table 29 reports concordance statistics for cycles in several international variables. The US Federal Funds rate classical cycle has very strong correspondence with all four cycles of economic activity - exhibiting significant concordance with the SARB 
business cycle, GDP growth rate cycle as well as the growth rate and classical cycles of industrial production. This is the only financial variable in classical cycle form with this property. The classical cycle of US long-term interest rates also exhibits strong and significant co-movement with classical and growth rate cycles in industrial production, as well as mild co-movement with the GDP growth rate cycle. Classical cycles in the MSCI emerging market share index exhibit significant concordance with the growth rate cycle in GDP, but no concordance with any other cycle in real activity.

Note that classical cycles in other international share indices as well as an aggregate emerging market bond index, all experience strong upward trends. Consequently, it seems sensible to consider these indices in growth rate cycle, as opposed to classical cycle, form.

\subsection{ConCordance of Growth Rate CyCles in FinANCIAL VARIABLES AND CyCLES IN REAL ECONOMiC ACTIVITY}

Table 30 shows that the M3 growth rate cycle exhibits statistically significant comovement with the classical industrial production cycle. Although similar evidence is not found for the SARB business cycle, it does provide some preliminary proof that the M3 may be a better leading indicator of real activity than the M1, which is used in the Reserve Bank’s composite leading indicator (Pretorius and Venter 2004).

From Table 31 it can be deduced that none of the local stock market indices are significant leading indicators when considered in a growth rate cycle form. Again, this contrasts with the use of a share index deviation cycle in the South African Reserve Bank's composite leading indicator (Pretorius and Venter 2004). Table 32 shows that growth rates in both US and emerging stock market indices do not have significant concordance with real activity cycles in South Africa. This is in contrast with our findings of significant concordance when the levels of the emerging market share index are considered. Additionally, significant and large concordance is found between the growth rate of the JP Morgan emerging market bond index and the growth rate cycle of GDP. 
Lastly, Table 33 reports the results concerning the concordance between growth rate cycles in different exchange rates with various real activity cycles. All of the evidence is related to industrial production, as opposed to GDP, cycles. This is not unexpected in the light of the widely debated impact of Rand gyrations on manufactured exports. It appears that the growth rate cycle in the real rand-dollar exchange rate exhibits significant concordance with the industrial production classical cycle (at a 15\% level) and, though weaker, with the industrial production growth rate cycle (at a $25 \%$ level). Some evidence of significant correspondence is also found for the growth rate in the nominal rand-dollar exchange rate as well as the real effective exchange rate.

The implications of the results reported in this as well as the previous section may be greatly elucidated if the concordance behaviour of different financial variable cycles can be compared in a systematic fashion. This is attempted in the following section.

\subsection{SUMMARY OF CONCORDANCE RESULTS}

Tables 34 and 35 presents all financial variables of which their classical cycles (Table 34) or growth rate cycles (Table 35) exhibit statistically significant co-movement with cycles in real economic activity. The tables report the monthly lead range for which the particular co-movement is maximised for the particular sample.

This offers a useful summary for a preliminary ${ }^{18}$ comparison with the variables used by the South African Reserve Bank in their leading composite indicator. In South Africa, the composite leading indicator contains, among others, the growth rate of real M1 money supply, the growth rate of a JSE share price index as well as an interest rate spread (Venter and Pretorius 2004: 69). The use of the real M1 and JSE variables, though, are questionable in the light of the evidence from Tables 34 and 35.

\footnotetext{
${ }^{18}$ The comparison is necessarily preliminary as it only accounts for business cycle conformity and not the crucial second criterion for a suitable leading indicator, namely stability of the lead interval. The concordance results only identify variables unfit for further analysis, as lead interval stability is only evaluated for those variables that successfully pass the concordance filtering test.
} 
Regarding monetary aggregates it is clear that real M3 performs better as leading indicator of classical cycles relative to real M1. This holds for both the levels (classical cycle) and growth rate of real M3. The M1 classical cycle exhibits significant co-movement only with growth rate cycles in industrial production. This does not agree with the Reserve Bank findings that M1 growth is related to the growth rate cycle in GDP. As far as the stock market is concerned, our evidence is even more contradictory. No growth rate in any of the local share price indices appear to be significant, while only the levels (i.e. classical cycles) in the Resources Index appear to exhibit significant co-movement with classical cycles in real activity.

The results support the use of the yield curve as leading indicator at a longer horizon, although interest rates (notably the nominal three-month Treasury bill yield) perform better over shorter leads. The absence of any international financial variables from the SARB's composite leading indicator is also a potential deficiency. The concordance statistics of classical cycles in US interest rates with cycles in South African economic activity are among the highest for all of the variables studied. Moreover, the growth rate in the JPM EMBI has significant concordance with growth rate cycles in South African GDP. However, bilateral R/\$ exchange rates appear to be largely co-moving with industrial production cycles (rather than overall GDP). The real effective rand, though, exhibit statistically significant co-movement with the GDP growth rate cycle. 
Table 34:

Statistically significant leading indicators (with indicator cycle in classical form) with optimal lead ranges in months (p-values for the null of zero concordance indicated in brackets)

\begin{tabular}{|c|c|c|c|c|}
\hline $\begin{array}{l}\text { Financial Variable } \\
\text { Classical Cycle }\end{array}$ & SARB & $\begin{array}{l}\text { Industrial } \\
\text { Production }\end{array}$ & GDP & $\begin{array}{l}\text { Industrial } \\
\text { Production }\end{array}$ \\
\hline & Official Cycle & Classical Cycle & Gr. rate Cycle & Gr. rate Cycle \\
\hline $\begin{array}{l}\text { Real M1 } \\
\text { monetary aggregate }\end{array}$ & & & & $\begin{array}{l}{[1-3]} \\
(0.241)\end{array}$ \\
\hline $\begin{array}{l}\text { Real M3 } \\
\text { monetary aggregate }\end{array}$ & $\begin{array}{l}{[1-3]} \\
(0.138)\end{array}$ & $\begin{array}{l}{[1-3]} \\
(0.065)\end{array}$ & & \\
\hline $\begin{array}{l}3 \text { month Treasury bill yield } \\
\text { (nominal) }\end{array}$ & $\begin{array}{r}{[1-3]} \\
(0.011)\end{array}$ & & & \\
\hline $\begin{array}{l}3 \text { month Treasury bill yield } \\
\text { (real) }\end{array}$ & $\begin{array}{l}{[1-3]} \\
(0.083)\end{array}$ & & & $\begin{array}{l}{[1-3]} \\
(0.203)\end{array}$ \\
\hline $\begin{array}{l}12 \text { month NCD rate } \\
\text { (nominal) }\end{array}$ & $\begin{array}{l}{[1-3]} \\
(0.134)\end{array}$ & & $\begin{array}{l}{[1-3]} \\
(0.157)\end{array}$ & \\
\hline $\begin{array}{l}10 \text { year Government Bond } \\
\text { yield (real) }\end{array}$ & $\begin{array}{l}{[1-3]} \\
(0.162)\end{array}$ & & & \\
\hline Yield Curve & $\begin{array}{l}{[9-12]} \\
(0.188)\end{array}$ & $y$ & & \\
\hline JSE Resources Index & $\begin{array}{l}{[6-9]} \\
(0.228)\end{array}$ & $\begin{array}{l}{[6-9]} \\
(0.071)\end{array}$ & & \\
\hline US Federal Funds Rate & $\begin{array}{l}{[6-9]} \\
(0.147)\end{array}$ & $\begin{array}{l}{[1-3]} \\
(0.001)\end{array}$ & $\begin{array}{l}{[1-3]} \\
(0.004)\end{array}$ & $\begin{array}{l}{[1-3]} \\
(0.131)\end{array}$ \\
\hline US 10 yr Govt Bond yield & & $\begin{array}{l}{[1-3]} \\
(0.199) \\
\end{array}$ & $\begin{array}{l}{[3-6]} \\
(0.069)\end{array}$ & $\begin{array}{l}{[3-6]} \\
(0.003)\end{array}$ \\
\hline $\begin{array}{l}\text { MSCI Emerging Market } \\
\text { Share Index }\end{array}$ & & $\sqrt{8}$ & $\begin{array}{l}{[3-5]} \\
(0.234)\end{array}$ & \\
\hline
\end{tabular}

\section{Table 35:}

Statistically significant leading indicators (with indicator cycle in twelve-month growth rate form) with optimal lead ranges in months (p-values for the null of zero concordance indicated in brackets)

\begin{tabular}{|c|c|c|c|c|}
\hline $\begin{array}{l}\text { Financial Variable } \\
\text { Growth Rate Cycle }\end{array}$ & SARB & $\begin{array}{c}\text { Industrial } \\
\text { Production }\end{array}$ & GDP & $\begin{array}{c}\text { Industrial } \\
\text { Production }\end{array}$ \\
\hline & Official Cycle & Classical Cycle & Gr. rate Cycle & Gr. rate Cycle \\
\hline $\begin{array}{l}\text { Real M3 } \\
\text { monetary aggregate }\end{array}$ & & $\begin{array}{l}{[3-5]} \\
(0.086) \\
\end{array}$ & & \\
\hline $\begin{array}{l}\text { JP Morgan Emerging Market } \\
\text { Bond Index }\end{array}$ & & & $\begin{array}{l}{[1-3]} \\
(0.036)\end{array}$ & \\
\hline $\begin{array}{l}\text { Real } \\
\text { Effective Rand }\end{array}$ & & $\begin{array}{l}{[1-3]} \\
(0.165)\end{array}$ & & \\
\hline $\begin{array}{l}\text { Nominal Rand-Dollar } \\
\text { Exchange Rate }\end{array}$ & & $\begin{array}{l}{[2-4]} \\
(0.161)\end{array}$ & & \\
\hline $\begin{array}{l}\text { Real Rand-Dollar } \\
\text { Exchange Rate }\end{array}$ & & $\begin{array}{l}{[2-4]} \\
(0.081)\end{array}$ & & $\begin{array}{l}{[1-3]} \\
(0.173)\end{array}$ \\
\hline
\end{tabular}




\subsection{A CAUTIONARY REMARK}

The concordance statistics presented in the preceding sections should be interpreted with caution. In particular, the results for the SARB official business cycle should be treated with care. The SARB cycle has its last turning in 1999, while the financial variables usually continue to experience cyclical turning points post-1999. The concordance statistic may, therefore, overstate the relation between states in the SARB business cycle and the financial variable cycle if the cycle in the financial variable experiences frequent switches between states while the SARB business cycle remains in a particular regime. Consequently, the economist should have a lucid understanding of the preliminary role of the concordance statistic if the study goal is leading indicator evaluation. As the following chapters will demonstrate, it is appreciably difficult to obtain variables that satisfy all of the criteria to act as leading indicators of the official SARB cycle. It is worth noting, though, that the problem is perhaps less severe in the case of the real activity cycles such as the GDP growth rate cycle and the classical and growth rate cycles in industrial production.

\subsection{COMPARISON WITH PREVIOUS CONCORDANCE STUdies}

While leading indicator studies abound in the literature, specific studies on relationships in the cyclicality of stock markets and real economic activity are scant. Avouyi-Dovi and Matheron (2005) use the concordance statistic as opposed to the conventional correlation concepts. However, these authors do not evaluate leading indicator properties, but only report coincident concordance statistics for cycles in national MSCI return indices and GDP in levels (see Table 36). Moreover, the use of return indices, as opposed to share price indices, prevents direct comparison with concordance statistics obtained for the South African case. 
Table 36:

Concordance of classical cycles in share return indices and GDP

\begin{tabular}{|l|l|}
\hline Country & $\begin{array}{l}\text { Concordance } \\
\text { at lag 0 }\end{array}$ \\
\hline USA & $0.69^{*}$ \\
\hline France & 0.62 \\
\hline Germany & 0.63 \\
\hline UK & 0.59 \\
\hline Italy & 0.55 \\
\hline
\end{tabular}

* Statistically significant at the 5\% level using the Harding and Pagan test discussed earlier

Source: Avouyi-Dovi and Matheron (2005: 24)

The only application of concordance analysis to South African financial variables to date is by Du Plessis (2005), who analyses the correspondence between cycles in quarterly short-term nominal and real interest rates in six emerging markets, including South Africa. Table 37 reports the Du Plessis (2005) concordance statistics for these countries (with statistical significance based on the same Harding and Pagan test described earlier). In addition, the concordance results calculated in preceding sections are also reported for purposes of comparison.

Table 37:

Concordance of classical cycles in short-term interest rates and GDP

\begin{tabular}{|c|c|c|c|c|c|c|c|}
\hline Country & Israel & Korea & Mexico & Peru & $\begin{array}{c}\text { Philip- } \\
\text { pines }\end{array}$ & $\begin{array}{l}\text { South } \\
\text { Africa }\end{array}$ & $\begin{array}{l}\text { South } \\
\text { Africa }\end{array}$ \\
\hline Sample period & $\begin{array}{l}1980- \\
2004\end{array}$ & $\begin{array}{l}1970- \\
2004\end{array}$ & $\begin{array}{l}1980- \\
2004\end{array}$ & $\begin{array}{l}1979- \\
2004\end{array}$ & $\begin{array}{l}1981- \\
2004\end{array}$ & $\begin{array}{l}1970- \\
2004\end{array}$ & $\begin{array}{l}1986- \\
2004\end{array}$ \\
\hline $\begin{array}{l}\text { Nominal short- } \\
\text { term interest rate }\end{array}$ & $0.22 * *$ & -0.02 & $-0.33 * *$ & -0.07 & -0.13 & 0.02 & $0.48 * * *$ \\
\hline $\begin{array}{l}\text { Real short-term } \\
\text { interest rate }\end{array}$ & $0.45 * * *$ & 0.13 & $0.46 * * *$ & 0.12 & -0.08 & 0.09 & $0.34 * *$ \\
\hline
\end{tabular}

\# The SARB official cycle instead of GDP is used although these are fairly comparable

* Significant at $25 \% * *$ Significant at $15 \% * * *$ Significant at $5 \%$

Source: Du Plessis (2005) and own calculations

While the Du Plessis (2005) study does not find significant coincident concordance between classical cycles in nominal or real short-term interest rates and GDP in South Africa, this study reports highly significant concordance. Turning points for the nominal interest rate in the two studies correspond for the period 1986-2003, indicating that the differences in the value and statistical significance of the concordance measure for the nominal rate is possibly due to the difference in sample 
period $^{19}$. Turning points for the real short-term interest rate do not correspond in the two studies, due to the differences in inflation horizon assumed when calculating proxies for inflation expectations. The Du Plessis (2005) study uses an annual inflation rate, while this study uses a quarterly inflation rate for the short-term real interest rate ${ }^{20}$. However, in an earlier study, Du Plessis (2004) do find statistically significant concordance results based on the sample period 1990-2003. Du Plessis (2004) finds significant four-quarter lagged concordance (at a 5\% level) of 0.405 between the ex ante real short-term rate ${ }^{21}$ and GDP, i.e. he finds evidence of forwardlooking real interest rates at a horizon of 1 year for the post-1990 sample. This compares favourably with the statistically significant twelve-month lagged concordance result of 0.11 (significant at 15\%) for the conventional real short-term interest rate and the official SARB business cycle obtained in this study.

The concordance results derived in this chapter at best only provide preliminary evidence on which financial variables are suitable leading indicators, as it is concerned solely with the first criterion for successful leading indicators, namely business cycle conformity. The following chapter investigates the second criterion, namely consistency with which turning points in financial variables lead turning points in the business cycle. As will be shown, very few financial variables meet this critical requirement.

\footnotetext{
${ }^{19}$ The Du Plessis (2005) study uses the sample period 1970-2004 for the short-term interest rate.

${ }^{20}$ Annual inflation rates, however, are used in this study where real long-term interest rates are calculated.

${ }^{21}$ See section 2.1.1 for a discussion on different real interest rate concepts.
} 


\section{CHAPTER 5 LEAD TIME INTERVALS BETWEEN CYCLICAL TURNING POINTS IN FINANCIAL VARIABLES AND BUSINESS CYCLE TURNING POINTS}

The preceding concordance analysis concentrates on co-movement between the particular financial series and the business cycle over all data points. Adherence to the requirement of co-movement, however, does not imply usefulness as leading indicator - as a leading indicator is traditionally concerned with the forecasting of the time duration up and until a turning point in real economic activity (Granger 1989). The concordance analysis should, therefore, be considered a filtering operation, as it identifies those financial variables that transmit an excessive number of false signals concerning turning points in real economic activity. Only after meeting the first comovement criterion is the potential indicator tested against the second, and critical, requirement - the consistency of lead times between turning points in the potential indicator and turning points in the real economy. Consequently, the following empirical analysis will focus exclusively on those financial variables of which cycles have been found to exhibit statistically significant concordance with cycles in real economic activity. The following sections will discuss this methodology and the accompanying results for the test of consistency of lead time intervals.

\subsection{MeThodology}

Burns and Mitchell proposed a procedure already in 1946 for the study of leading time intervals between turning points in the business cycle and turning points in potential leading indicators. These initial proposals were extended and refined by Moore at the NBER (Moore 1950; Granger 1989) and the Economic Cycle Research Institute (Achuthan and Banerji 2004). In this context, the analysis of lead intervals is a descriptive one and involves a large number of tables describing lead intervals from different perspectives. While Moore did use elementary statistical measures, such as the mean and standard deviation of leads, formal statistical tests were only recently proposed by Banerji (1999a).

These developments of the past six decades can be represented in a three-pronged approach to the analysis of lead intervals: 
(i) Matching of cyclical turning points in financial variables and real economic activity.

(ii) Thorough description of lead intervals.

(iii) Statistical tests of consistency of lead intervals.

The following two sections will attend to these steps and present the accompanying findings.

\subsection{Matching Of TURning Points ANd Description of LeAd INTERVALS}

The results are dependent on the matching process, which may, at first glance, seem straightforward, but requires definite procedures to render it at least tolerably objective. The matching process itself consists of two steps:

(i) Choice between like and opposite matching.

(ii) Application of matching rules (i.e. the actual matching).

The first step is the decision between matching like or opposite turning points, that is, matching peaks in the business cycle with peaks in the potential indicator (like matching) or with troughs (opposite matching). The same applies to matching troughs in the business cycle with indicator troughs (like matching) or indicator peaks (opposite matching). Hence, this choice depends on the pro- or counter-cyclical nature of the financial variables relative to the business cycle. In the literature, the correlation statistic is used to gauge pro- or counter-cyclicality. For example, Andreou et al (2000) use cross-correlations to establish the cyclicality of financial variables relative to industrial production in the United Kingdom. As previously demonstrated, the concordance statistic offers several improvements on the correlation statistic, while it can be interpreted in a similar fashion. Accordingly, this study employs the sign of the concordance statistic as an indication of the pro- or counter-cyclical nature of the different financial variables - which, in turn, informs the choice between like or opposite matching.

The second step in the matching process involves the application of particular rules to ensure an objective matching process. This is especially important in those cases where more than one possible turning point in the indicator can be related to a business cycle turning point. These rules ensure the necessary self-restraint on the 
part of the researcher, "lest the data be forced to suit preconceived notions" (Burns and Mitchell, 1946: 118). Burns and Mitchell (1946) suggest that a turning point in the potential leading indicator $(\mathrm{L})$ must meet the following two criteria to qualify as a corresponding turning point relative to a turning point in the business cycle (B):

(i) There is no other corresponding turning point in the business cycle in the period between $\mathrm{L}$ and $\mathrm{B}$ (including the month in which $\mathrm{L}$ occurs).

(ii) There is no other corresponding turning point in the potential leading indicator in the period between L and B (including the month in which B occurs).

Tables 38 to 41 (see Appendix E) report inter alia the matching results for those financial variables whose classical and/or growth rate cycles exhibit significant concordance with cycles in real economic activity, as previously presented in Tables 34 and 35 respectively. Tables 38 to 41 report the results separately for the official SARB cycle, the GDP growth rate cycle as well as classical and growth rate cycles in industrial production.

The tables offer an appraisal of the success of the matching process by reporting the number of turning points in the potential indicator eligible for matching with business cycle turning points (column 3), the total number of business cycle turning points (column 4) and, finally, the number of matching pairs of turning points (column 5). Two questions are of concern here. Firstly, do the cyclical turning points in the indicator match all of the cyclical turning points in real economic activity? That is, does the value in column 5 equal, or nearly equal, the value in column 4? Secondly, how many false signals does the relevant indicator transmit? Put differently, does the value in column 5 equal, or nearly equal, the value in column 3? This is a particularly important part in the evaluation of a potential leading indicator and is, unfortunately, not covered by the formal statistical test presented later on. While the test provides an objective assessment of the stability of the lead duration, it takes as its input only those turning points in the leading indicator found to match turning points in the business cycle. The answers to the above-mentioned questions will, therefore, be used as filters prior to performing the statistical tests.

From Table 38 it appears that most of the cycles in financial variables that are matched with the official SARB cycle pass the first question, that is, their turning 
points match all of the turning points in the SARB cycle. However, the number of false signals transmitted (related to the second question) is quite high for most variables, except for peaks in the US Federal Funds rate. Results from Tables 39, 40 and 41 can be interpreted in a similar manner. In Table 39 only troughs in the JP Morgan Emerging Market Bond Index appear to offer reasonable matching with troughs in the GDP growth rate cycle. The troughs in the real M3 classical cycle, real M3 growth rate cycle and the US 10-year government bond yield classical cycle have a relatively successful match with troughs in the industrial production classical cycle (see Table 40). No classical or growth rate cycle in any of the financial variables achieve successful matches between their turning points and turning points in the growth rate cycle of industrial production (see Table 41).

The above-mentioned results, however, are only the "highly" successful matches, for which both of the filtering questions have been answered in the affirmative. It does not provide an assessment of the relative performance of the other financial variables. Tables 42 and 43 (see below) summarise the results concerning the success of the matching procedure for all of the cycles identified via the concordance testing in Chapter 4. The tables report (separately for classical and growth rate cycles) how well the matching process between selected cycles in financial variables and the various cycles in real activity meet the two requirements mentioned earlier:

(i) Is the number of matching pairs equal, or nearly equal ${ }^{22}$, to the number of turning points in the real economic cycle?

(ii) Is the number of extra turning points in the potential indicator equal, or nearly equal, to zero?

One point is allocated for each affirmative response, such that a score of 2 represents a "good" match where the financial variable cycle covers all business cycle turns with few false signals.

22 "Nearly equal" refers to difference by one turning point. 
Table 42:

Success of turning point matching for classical cycles in financial variables with cycles in real economic activity

\begin{tabular}{|c|c|c|c|c|c|}
\hline $\begin{array}{l}\text { Financial Variable } \\
\text { Classical cycle }\end{array}$ & & $\begin{array}{c}\text { SARB } \\
\text { Official } \\
\text { Cycle }\end{array}$ & $\begin{array}{c}\text { GDP } \\
\text { Gr. Rate } \\
\text { Cycle }\end{array}$ & $\begin{array}{c}\text { Industrial } \\
\text { Prod } \\
\text { Classical } \\
\text { Cycle }\end{array}$ & $\begin{array}{c}\text { Industrial } \\
\text { Prod } \\
\text { Gr. Rate } \\
\text { Cycle }\end{array}$ \\
\hline \multirow{2}{*}{$\begin{array}{l}\text { Real M1 } \\
\text { monetary aggregate }\end{array}$} & $\mathrm{P}$ & & & & 1 \\
\hline & $\mathrm{T}$ & & & & 0 \\
\hline \multirow{2}{*}{$\begin{array}{l}\text { Real M3 } \\
\text { monetary aggregate }\end{array}$} & $\mathrm{P}$ & 1 & & 0 & \\
\hline & $\mathrm{T}$ & 1 & & 2 & \\
\hline \multirow{2}{*}{$\begin{array}{l}\text { 3-month Treasury bill yield } \\
\text { (nominal) }\end{array}$} & $\mathrm{P}$ & 1 & & & \\
\hline & $\mathrm{T}$ & 1 & & & \\
\hline \multirow{2}{*}{$\begin{array}{l}\text { 3-month Treasury bill yield } \\
\text { (real) }\end{array}$} & $\mathrm{P}$ & 1 & & & 1 \\
\hline & $\mathrm{T}$ & 0 & & & 1 \\
\hline \multirow{2}{*}{$\begin{array}{l}\text { 12-month NCD rate } \\
\text { (nominal) }\end{array}$} & $\mathrm{P}$ & 1 & 0 & & \\
\hline & $\mathrm{T}$ & 1 & 0 & & \\
\hline \multirow{2}{*}{$\begin{array}{l}\text { 10-year govt bond yield } \\
\text { (real) }\end{array}$} & $\mathrm{P}$ & 1 & & & \\
\hline & $\mathrm{T}$ & 0 & & & \\
\hline \multirow[t]{2}{*}{ Yield curve } & $\mathrm{P}$ & 1 & & & \\
\hline & $\mathrm{T}$ & 1 & & & \\
\hline \multirow[t]{2}{*}{ JSE Resources Index } & $\mathrm{P}$ & 1 & & 0 & \\
\hline & $\mathrm{T}$ & 1 & & 0 & \\
\hline \multirow[t]{2}{*}{ US Federal Funds rate } & $\mathrm{P}$ & 2 & 1 & 0 & 1 \\
\hline & $\mathrm{T}$ & 1 & 1 & 0 & 1 \\
\hline \multirow[t]{2}{*}{ US 10-year govt bond yield } & $\mathrm{P}$ & 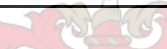 & 0 & 0 & 1 \\
\hline & $\mathrm{T}$ & & 0 & 2 & 1 \\
\hline \multirow{2}{*}{$\begin{array}{l}\text { MSCI Emerging Market } \\
\text { Share Index }\end{array}$} & $\mathrm{P}$ & & 0 & & \\
\hline & $\mathrm{T}$ & 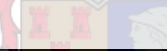 & 0 & & \\
\hline
\end{tabular}

Table 43:

Success of turning point matching for growth rate cycles in financial variables with cycles in real economic activity*

\begin{tabular}{|c|c|c|c|c|}
\hline $\begin{array}{l}\text { Financial Variable } \\
\text { Growth rate cycle }\end{array}$ & & $\begin{array}{c}\text { GDP } \\
\text { Growth } \\
\text { Rate Cycle }\end{array}$ & $\begin{array}{c}\text { Industrial } \\
\text { Prod } \\
\text { Classical } \\
\text { Cycle }\end{array}$ & $\begin{array}{c}\text { Industrial } \\
\text { Prod } \\
\text { Gr. Rate } \\
\text { Cycle }\end{array}$ \\
\hline \multirow{2}{*}{$\begin{array}{l}\text { Real M3 } \\
\text { monetary aggregate }\end{array}$} & $\mathrm{P}$ & & 0 & \\
\hline & $\mathrm{T}$ & & 2 & \\
\hline \multirow{2}{*}{$\begin{array}{l}\text { JP Morgan Emerging Market } \\
\text { Bond Index }\end{array}$} & $\mathrm{P}$ & 0 & & \\
\hline & $\mathrm{T}$ & 2 & & \\
\hline \multirow[t]{2}{*}{ Real Effective Rand } & $\mathrm{P}$ & & 1 & \\
\hline & $\mathrm{T}$ & & 1 & \\
\hline \multirow{2}{*}{$\begin{array}{l}\text { Nominal Rand-Dollar } \\
\text { Exchange Rate }\end{array}$} & $\mathrm{P}$ & & 1 & \\
\hline & $\mathrm{T}$ & & 1 & \\
\hline \multirow{2}{*}{$\begin{array}{l}\text { Real Rand-Dollar } \\
\text { Exchange Rate }\end{array}$} & $\mathrm{P}$ & & 1 & 1 \\
\hline & $\mathrm{T}$ & & 1 & 1 \\
\hline
\end{tabular}

* Table 35 reported no variables in growth rate form with significant concordance with the SARB business cycle.

Apart from information on the success of matching, Tables 38 to 41 also present a decomposition of lead or lag times, i.e. the difference in months between the turning 
point in the potential indicator and a turning point in real activity. Inspection of these tables yield the conclusion that, in many cases, lags relative to the business cycle occur as often as leads do. This conveys a serious warning against the use of significant co-movement (measured by the concordance statistic or the conventional correlation coefficient) as the only requirement for suitability as leading indicator. A description of lead or lag times, though, do not provide an objective evaluation of the capacity of turning points in a financial variable to predict business cycle turns at a consistent horizon. The following section considers a statistical test proposed by Banerji (1999a) for this purpose.

\subsection{Statistical Tests OF LeAd InTERVALs: Methodology}

A statistical measure is required to gauge the consistency of lead duration for a potential leading indicator. This involves a null hypothesis of no statistically significant time difference between turning points in the potential indicator and business cycle turning points - which should be tested against the alternative hypothesis of statistically significant timing differences (Banerji, 1999: 3 and Siegel, 1956: 88). This type of "direct" hypothesis testing is perhaps less familiar to econometricians, who usually perform hypothesis testing within a regression context. It is, however, an important tool where a precisely defined hypothesis is to be tested outside the modelling framework - and one that is common to the general statistics literature $^{23}$.

The main challenge in the choice of a statistic for hypothesis testing on lead intervals is the small size of the sample. In this study, for example, there are no more than eight peaks and eight troughs for any of the cycles in real activity in the sample period. The small sample sizes restrict the confidence with which statistical inference can be conducted. As conventional statistical tests rely on assumptions about the underlying population to make probability statements, these tests are inappropriate (and could be misleading) where such assumptions cannot be supported by the data. The small sample size in this study is one such case. As an alternative, Banerji (1999a) proposes non-parametric tests for which exact probability statements can be

\footnotetext{
${ }^{23}$ See Chapters 1 to 3 of Siegel (1956) for a discussion on applications to the social sciences.
} 
derived, regardless of the shape of the population distribution, for the following null and alternative hypotheses (Banerji 1999a: 4):

$\mathrm{H}_{0}$ : $\quad$ Lead time between turning point in leading indicator and turning point in business cycle is not significantly different from zero.

$\mathrm{H}_{\mathrm{a}}$ : $\quad$ Lead time is significantly greater than zero months.

The Banerji non-parametric tests are based on a comparison of two sets of turning point samples - one set consisting of turning points for the potential leading indicator and another set containing turning points for the cycle in real economic activity. The two samples must be of equal size - indicating that such comparison is only possible for those financial variables that have earned a score of 1 or 2 in the assessment of matching success as reported in Tables 42 and 43. The test is based on the timing differences between the matching turning points in the potential indicator and the business cycle and is called the Fisher (1935) randomization test for "matched pairs" - where a pair of turning points (one for the potential and one for the business cycle) is "matched" by calculating the difference in timing between them.

For example, the comparison of classical cycle peaks in the US 10 year government bond yield and growth rate cycle peaks in South African industrial production yield the following timing differences (where a positive value indicates that the peak in the US bond yield led the matching peak in industrial production growth, while a negative value indicates that the peak in the US bond lagged the matching peak in industrial production growth $\left.{ }^{24}\right)$ :

$$
10 ; \quad 7 ; \quad 6 ; \quad-2 ; \quad 5
$$

The rationale of the test is that, under the null hypothesis, positive timing differences (leads) and negative differences (lags) are equally likely to occur, such that the sum of such differences $(S)$ over the sample should equal zero. The sampling distribution of $S$ consists of all possible occurrences of $S$ derived from permutation of the signs of the differences. Accordingly, under the null hypothesis there are $2^{N}$ equally possible outcomes for $S$, with $N$ the number of matched turning point pairs. Returning to the

\footnotetext{
${ }^{24}$ This is consistent with the convention followed by Banerji (1999a).
} 
above example, this implies that there are $32\left(2^{5}\right)$ possible outcomes. Table 44 reports these outcomes, with the last column presenting the value of $S$ for each case (the fourth case is the original set of timing differences).

Table 44:

All possible permutations for timing differences between peaks in US 10 year government bond yield classical cycle and peaks in the industrial production growth rate cycle

$\begin{array}{lrrrrrr}{[1]} & 10 & 7 & 6 & 2 & 5 & 30 \\ {[2]} & 10 & 7 & 6 & -2 & 5 & 26 \\ {[3]} & 10 & 7 & 6 & -2 & 5 & 26 \\ {[4]} & 10 & 7 & 6 & -2 & 5 & 26 \\ {[5]} & 10 & 7 & 6 & 2 & -5 & 20 \\ {[6]} & 10 & 7 & -6 & 2 & 5 & 18 \\ {[7]} & 10 & 7 & 6 & -2 & -5 & 16 \\ {[8]} & 10 & -7 & 6 & 2 & 5 & 16 \\ {[9]} & 10 & -7 & 6 & -2 & 5 & 12 \\ {[10]} & -10 & 7 & 6 & 2 & 5 & 10 \\ {[11]} & 10 & 7 & -6 & 2 & -5 & 8 \\ {[12]} & 10 & -7 & 6 & 2 & -5 & 6 \\ {[13]} & -10 & 7 & 6 & -2 & 5 & 6 \\ {[14]} & 10 & -7 & -6 & 2 & 5 & 4 \\ {[15]} & 10 & -7 & 6 & -2 & -5 & 2 \\ {[16]} & 10 & -7 & -6 & -2 & 5 & 0 \\ {[17]} & -10 & 7 & 6 & 2 & -5 & 0 \\ {[18]} & -10 & 7 & -6 & 2 & 5 & -2 \\ {[19]} & -10 & 7 & -6 & 2 & 5 & -2 \\ {[20]} & -10 & -7 & 6 & 2 & 5 & -4 \\ {[21]} & -10 & 7 & 6 & -2 & -5 & -4 \\ {[22]} & -10 & -7 & 6 & 2 & 5 & -4 \\ {[23]} & 10 & -7 & -6 & 2 & -5 & -6 \\ {[24]} & -10 & 7 & -6 & -2 & 5 & -6 \\ {[25]} & -10 & -7 & 6 & -2 & 5 & -8 \\ {[26]} & 10 & -7 & -6 & -2 & -5 & -10 \\ {[27]} & -10 & 7 & -6 & 2 & -5 & -12 \\ {[28]} & -10 & -7 & 6 & 2 & -5 & -14 \\ {[29]} & -10 & 7 & -6 & -2 & -5 & -16 \\ {[30]} & -10 & -7 & -6 & 2 & 5 & -16 \\ {[31]} & -10 & -7 & 6 & -2 & -5 & -18 \\ {[32]} & -10 & -7 & -6 & -2 & -5 & -30\end{array}$

The null hypothesis is rejected when the observed sum of differences falls within the region of rejection, which consists of those $\alpha \%$ most extreme outcomes of $S$, where $\alpha$ is the chosen level of significance. To calculate the probability under the null hypothesis that the observed value falls within the rejection region, all possible values for $S$ greater or equal to the current value are calculated. As already illustrated, this is achieved by switching the signs one by one to generate all the possible permutations. For the previous example these are all the outcomes for which $S$ is greater or equal to 26, as reported in the following table: 
Table 45:

Extreme permutations for timing differences between peaks in US 10 year government bond yield classical cycle and peaks in the industrial production growth rate cycle

$\begin{array}{rrrrrrr}{[1]} & 10 & 7 & 6 & 2 & 5 & 30 \\ {[2]} & 10 & 7 & 6 & -2 & 5 & 26 \\ {[3]} & 10 & 7 & 6 & -2 & 5 & 26 \\ {[4]} & \mathbf{1 0} & \mathbf{7} & \mathbf{6} & \mathbf{- 2} & \mathbf{5} & \mathbf{2 6}\end{array}$

The ratio $(q)$ of the number of such outcomes to the total number of possibilities under the null hypothesis $\left(2^{N}\right)$ is then calculated. If this value exceeds $\alpha$, the null hypothesis of no differences is rejected in favour of the alternative. In the preceding example, $q$ is calculated as $4 / 32=0.125$ (i.e. the number of extreme cases ( $4-$ see Table 45) divided by the total number of permutations (32 - see Table 44)). As 0.125 is smaller than $\alpha=0.15$ (for example) one may conclude that the null hypothesis (of no lead time differences) can be rejected at a significance level of $15 \%$.

Banerji's (1999a) proposals concerning the randomization test contain an important further innovation. Banerji's insight is that the test can be conducted for an increasing lead span - enabling the testing of a range of null hypotheses. The "baseline" null hypothesis is that the difference in timing at turns exceeds zero. Banerji proposes subtracting one from each of the leads - resulting in the following adjusted null hypothesis: the difference in timing at turns exceeds one month. Hence, by subtracting one from the leads and iterating the procedure, one may generate hypothesis tests that the difference in timing at turns exceeds zero, one, two, three, etc. The set of $q$-values obtained from each of these null hypotheses are called the lead profile (Banerji, 1999a: 4). Table 46 shows the set of hypotheses for the previous example:

Table 46:

The range of null hypotheses for leads of different durations

\begin{tabular}{|l|l|l|l|l|l|}
\hline \multicolumn{5}{|c|}{ Sample } & \multicolumn{1}{c|}{ Null Hypothesis } \\
\hline 10 & 7 & 6 & -2 & 5 & Zero timing difference \\
\hline 9 & 6 & 5 & -3 & 4 & Timing difference (lead) of at least 1 month \\
\hline 8 & 5 & 4 & -4 & 3 & Timing difference (lead) of at least 2 months \\
\hline 7 & 4 & 3 & -5 & 2 & Timing difference (lead) of at least 3 months \\
\hline.. &.. &.. &.. &.. & Etc. \\
\hline
\end{tabular}

The significance levels for rejection of the null hypotheses can then be presented graphically (called a "lead profile chart"), creating an easy communication device for 
the researcher to present the decline in his or her "confidence" concerning a lead duration of a particular length ${ }^{25}$.

\subsection{STATISTICAL TESTS OF LEAD INTERVALS: RESULTS}

Tables 47 to 50 present the lead profiles of those cycles in financial variables that have earned a score of 1 or 2 in the assessment of matching success as reported in Tables 42 and 43. It is important, though, to consider the sample size when interpreting the results. While non-parametric tests do not require larger sample sizes for distribution purposes, a sample of, say, two pairs do not offer sufficient information in which to isolate patterns via statistical procedures. As statistical tests (parametric and non-parametric alike) may be misled by such samples, a minimum sample size of three pairs is enforced.

When applying this minimum sample size requirement, Table 47 does not report any variable with a significant lead profile. It appears that only troughs in the real M3 and three-month Treasury bill yield classical cycles roughly match the small number of troughs reported in the official SARB cycle for the sample period and that even these lead business cycle troughs inconsistently. The like is true of the lead profiles obtained for potential indicators of the GDP growth rate cycle (see Table 48). Neither peaks in the US Federal Funds rate classical cycle nor peaks or troughs in the growth rate cycle of the JP Morgan Emerging Market Bond Index yield confidence levels that are even closely acceptable in a statistical sense.

The lead profile results for potential leading indicators of cycles in industrial production yield more positive evidence. Table 49 reports significant lead profiles for growth rate cycle troughs in the real effective rand and growth rate cycle peaks in the real rand-dollar exchange rate relative to classical cycle peaks of industrial production. Figures 1 and 2 present the accompanying lead profile charts. The null

\footnotetext{
${ }^{25}$ The $\mathrm{R}$ statistical language is used to program functions that perform the randomization tests automatically (R Foundation for Statistical Computing 2005). Note also that leads of zero months (that is, where a turning point in the financial variable cycle coincide with a business cycle turning point) are ignored in the calculations, as these do not affect the outcomes of the randomization tests (Banerji 1999a: 11).
} 
hypotheses of a lead interval not exceeding one month and two months are rejected for both the real effective rand and real rand-dollar. Put differently, the troughs in the real effective rand growth rate cycle as well as the peaks in the real rand-dollar growth rate cycle consistently lead matching peaks in industrial production by at least two months, at a statistically significant level of $25 \%$.

Figure 1:

Lead profile chart of growth rate cycle troughs in the real effective rand relative to peaks in the industrial production classical cycle

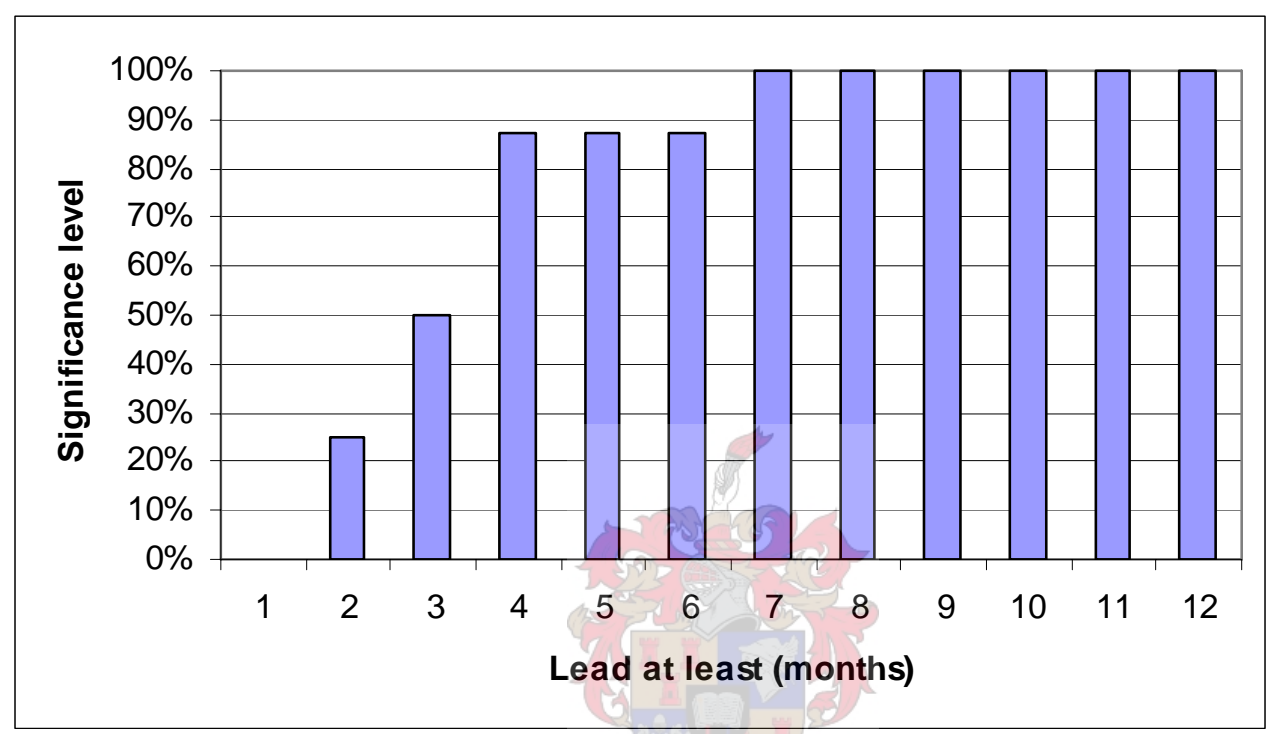

Figure 2:

Lead profile chart of growth rate cycle peaks in the real rand-dollar exchange rate relative to peaks in the industrial production classical cycle

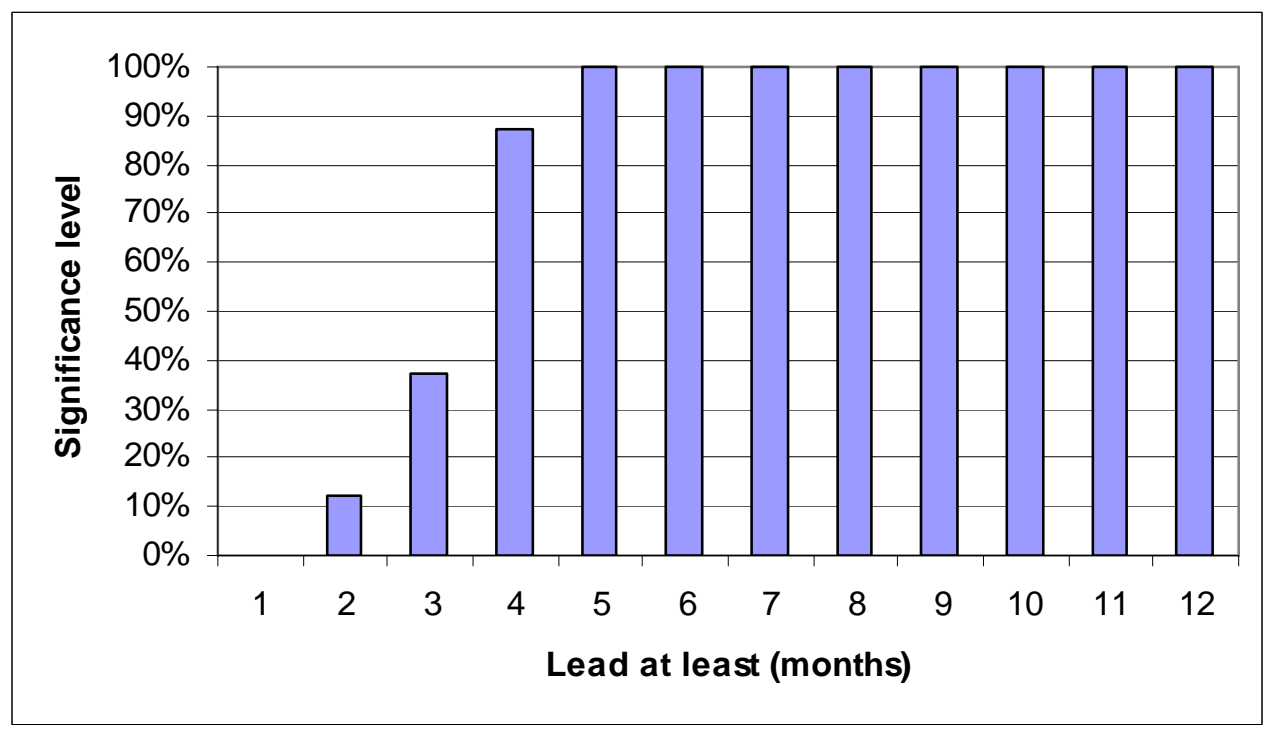


Table 50 suggests a significant lead profile for classical cycle peaks in the US 10-year government bond yield relative to peaks in the industrial production growth rate cycle. Compared to the previous cases, the sample size is larger - containing five pairs. Figures 3 offers what is perhaps the only lead profile chart with an acceptable form: quite low initial values for $p$ that rise slowly to reach significance levels of $59 \%$ at lead times of five months. Hence, classical cycle peaks in the US 10-year government bond yield consistently lead growth rate cycle peaks in industrial production with at least three months at a statistically significant level of $25 \%$.

Figure 3:

Lead profile chart of classical cycle peaks in US 10-year government bond yield relative to peaks in the industrial production growth rate cycle

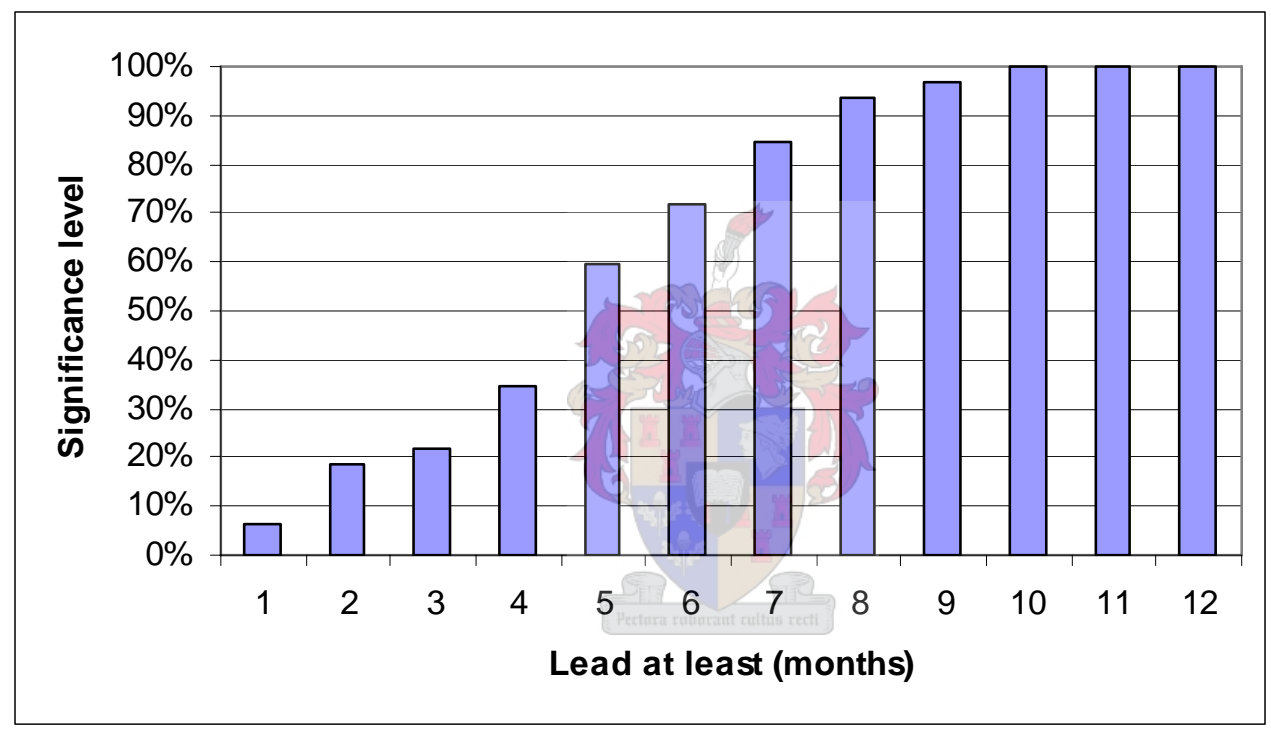

The results obtained here can be reconciled with the matching success scores presented earlier. Our comprehension of the behaviour of lead intervals is advanced by considering Tables 51 and 52. These tables are similar in format to Tables 34 and 35, which indicate the lead ranges at which the concordance statistics are maximised for the different financial variable cycles relative to cycles in real economic activity. Tables 51 and 52 synthesize two results:

(i) The tables report, where applicable, the statistically significant lead interval (at a level of $25 \%$ ) of turning points in the financial variable relative to business cycle turning points.

(ii) The tables also indicate which financial variables have earned a score of 2 concerning success of matching, by means of a "Y" in the particular cell. 
Table 51 reports the classical cycle results, while Table 52 considers the growth rate cycle findings. The tables highlight the central empirical conclusion of the study. No financial variable in the sample period 1986-2004 meets all of the requirements of a successful leading indicator for any of the cycles in South African real economic activity. Where matching has been successful, lead intervals are not consistent. Vice versa, where lead intervals are found to be consistent, matching is not generally successful - pointing to the existence of many extra turning points in the financial variable that may generate false signals.

Table 51:

Summary of lead interval findings for classical cycles in financial variables

\begin{tabular}{|c|c|c|c|c|c|}
\hline $\begin{array}{l}\text { Financial Variable } \\
\text { Classical cycle }\end{array}$ & & $\begin{array}{c}\text { SARB } \\
\text { Official } \\
\text { Cycle }\end{array}$ & $\begin{array}{c}\text { GDP } \\
\text { Gr. Rate } \\
\text { Cycle }\end{array}$ & $\begin{array}{c}\text { Industrial } \\
\text { Prod } \\
\text { Classical } \\
\text { Cycle }\end{array}$ & $\begin{array}{c}\text { Industrial } \\
\text { Prod } \\
\text { Gr. Rate } \\
\text { Cycle }\end{array}$ \\
\hline \multirow{2}{*}{$\begin{array}{l}\text { Real M1 } \\
\text { monetary aggregate }\end{array}$} & $P$ & & & & \\
\hline & $\mathrm{T}$ & & & & \\
\hline \multirow{2}{*}{$\begin{array}{l}\text { Real M3 } \\
\text { monetary aggregate }\end{array}$} & $\mathrm{P}$ & & & & \\
\hline & $\mathrm{T}$ & & & $\mathbf{Y}$ & \\
\hline \multirow{2}{*}{$\begin{array}{l}\text { 3-month Treasury bill yield } \\
\text { (nominal) }\end{array}$} & $\mathrm{P}$ & U & & & \\
\hline & $T$ & & & & \\
\hline \multirow{2}{*}{$\begin{array}{l}\text { 3-month Treasury bill yield } \\
\text { (real) }\end{array}$} & $\mathrm{P}$ & & & & \\
\hline & $\mathrm{T}$ & & & & \\
\hline \multirow{2}{*}{$\begin{array}{l}\text { 12-month NCD rate } \\
\text { (nominal) }\end{array}$} & $\mathrm{P}$ & & 5 & & \\
\hline & $\mathrm{T}$ & & & & \\
\hline \multirow{2}{*}{$\begin{array}{l}\text { 10-year govt bond yield } \\
\text { (real) }\end{array}$} & $\mathrm{P}$ & & & & \\
\hline & $\bar{T}$ & & & & \\
\hline \multirow{2}{*}{ Yield curve } & $\mathrm{P}$ & & & & \\
\hline & $\mathrm{T}$ & & & & \\
\hline \multirow[t]{2}{*}{ JSE Resources Index } & $\mathrm{P}$ & & & & \\
\hline & $\mathrm{T}$ & & & & \\
\hline \multirow[t]{2}{*}{ US Federal Funds rate } & $\mathrm{P}$ & $\mathbf{Y}$ & & & \\
\hline & $\mathrm{T}$ & & & & \\
\hline \multirow[t]{2}{*}{ US 10 -year govt bond yield } & $\mathrm{P}$ & & & & 3 months \\
\hline & $\mathrm{T}$ & & & $\mathbf{Y}$ & \\
\hline \multirow{2}{*}{$\begin{array}{l}\text { MSCI Emerging Market } \\
\text { Share Index }\end{array}$} & $\mathrm{P}$ & & & & \\
\hline & $\mathrm{T}$ & & & & \\
\hline
\end{tabular}


Table 52:

Summary of lead interval findings for growth rate cycles in financial variables

\begin{tabular}{|c|c|c|c|c|}
\hline $\begin{array}{l}\text { Financial Variable } \\
\text { Growth rate cycle }\end{array}$ & & $\begin{array}{c}\text { GDP } \\
\text { Growth } \\
\text { Rate Cycle }\end{array}$ & $\begin{array}{c}\text { Industrial } \\
\text { Prod } \\
\text { Classical } \\
\text { Cycle }\end{array}$ & $\begin{array}{c}\text { Industrial } \\
\text { Prod } \\
\text { Gr. Rate } \\
\text { Cycle }\end{array}$ \\
\hline \multirow{2}{*}{$\begin{array}{l}\text { Real M3 } \\
\text { monetary aggregate }\end{array}$} & $\mathrm{P}$ & & & \\
\hline & $\mathrm{T}$ & & $\mathbf{Y}$ & \\
\hline \multirow{2}{*}{$\begin{array}{l}\text { JP Morgan Emerging Market } \\
\text { Bond Index }\end{array}$} & $\mathrm{P}$ & & & \\
\hline & $\mathrm{T}$ & $\mathbf{Y}$ & & \\
\hline \multirow[t]{2}{*}{ Real Effective Rand } & $\mathrm{P}$ & & & \\
\hline & $\mathrm{T}$ & & 2 months & \\
\hline \multirow{2}{*}{$\begin{array}{l}\text { Nominal Rand-Dollar } \\
\text { Exchange Rate }\end{array}$} & $\mathrm{P}$ & & & \\
\hline & $\mathrm{T}$ & & & \\
\hline \multirow{2}{*}{$\begin{array}{l}\text { Real Rand-Dollar } \\
\text { Exchange Rate }\end{array}$} & $\mathrm{P}$ & & 2 months & \\
\hline & $\mathrm{T}$ & & & \\
\hline
\end{tabular}

\subsection{Comparison With Previous South African Studies}

Given the novelty of the technique to cycle analysis, few studies (both locally and internationally) are available employing the Banerji (1999a) lead profile tests when assessing leading indicator capacity. As far as can be determined, this study is possibly the first in the literature to apply the technique to financial variables. However, Van Rensburg (1990) investigates lead intervals for financial variables in South Africa in a descriptive fashion in an effort to construct a composite financial leading indicator for the official SARB business cycle. The process involved the scoring of different financial variables based on how well these meet the conformity and time interval criteria.

The scoring classification of Van Rensburg (1990), reported in Table 53, is not based on a formal statistical test, such as the one attempted in this study. Scores range from 1 (erratic) to 4 (very consistent) and are based on the standard deviation of lead times as suggested by Van Coller (1980).

Table 53:

Score classification for lead time consistency

\begin{tabular}{|c|c|c|}
\hline Score & Score Description & $\begin{array}{c}\text { Standard Deviation } \\
\text { Range (in months) }\end{array}$ \\
\hline 1 & Erratic & $>7$ \\
\hline 2 & Fairly inconsistent & {$[5 ; 7]$} \\
\hline 3 & Fairly consistent & {$[2 ; 4]$} \\
\hline 4 & Very consistent & $<2$ \\
\hline
\end{tabular}


The results for those financial variables with superior lead-time consistency are reported in Table 54. The list of variables reported by Van Rensburg (1990) is longer, due to a very broad definition of what constitutes a 'financial' variable. Table 51, however, only report variables common to both the Van Rensburg investigation and this study. The findings by Van Rensburg differ from the results obtained in the preceding sections. As mentioned, this study does not find any financial variable with consistent lead times relative to the SARB business cycle. This is in contrast to the finding by Van Rensburg that troughs in the three-month BA discount rate (comparable to the three-month Treasury bill yield) lead business cycle business cycle troughs fairly consistently by three months (see Table 53). In fact, all of the troughs of the three-month Treasury bill yield in the sample period of this study are found to lag corresponding troughs in the business cycle. Comparison, though, is not straightforward as Van Rensburg utilizes a sample period from 1970 to 1989 as opposed to the 1986 to 2004 sample period of this study.

Table 54:

Scoring results for financial variables that performed the best

\begin{tabular}{|l|c|c|}
\hline Financial variable & \multicolumn{2}{c|}{ Timing at } \\
\hline & Peaks (P) & Troughs (T) \\
\hline 3-month Bankers' Accept discount rate & 1 & 3 \\
\hline Industrial share prices & 2 & 1 \\
\hline
\end{tabular}




\section{CHAPTER 6 CONCLUSION}

The outcomes of the leading indicator tests in this study can be interpreted in several ways. It is advisable for the economist, though, to keep in mind the limitations of this study, as the results are obtained for a specific sample period applying the traditional model-free approach. Therefore, prior to presenting the final conclusions, the results are compared to those obtained using an econometric evaluation.

\subsection{Comparison with South African Probit Results}

The econometric approach involves a less traditional treatment of leading indicators, as it is generally concerned with co-movement of the potential indicator and real activity over all data points (see Chapter 3, Section 3.1 and 3.2 for a full discussion). Nonetheless, a comparison does provide perspective (albeit limited) on the quality of the results reported in this study.

The results obtained using the probit model may be the most appropriate for comparison purposes, as the probit model is concerned with modelling the probabilities of business cycle regimes, as opposed to conventional models aimed at value forecasts for real economic activity (such as GDP). Moolman (2003) attempts an evaluation of the forecasting power of financial variables in South Africa using a set of probit models. Each model utilizes a single financial variable to predict regimes (expansions and contractions) in the official SARB business cycle via recession probabilities. Should the recession probability exceed (fall below) an arbitrary threshold such as 0.5 , the business cycle phase is defined as a contraction (expansion). Hence, this study offers a useful analogy with the concordance analyses attempted earlier, as the concordance statistic is also aimed at relating cycle regimes (or phases) in real economic activity with regimes in the financial variable cycle. However, Moolman uses 1978-2000 as sample period, while the sample period for this study generally covers 1986-2004. Consequently, the Moolman findings include several monetary policy regimes, which will affect the results obtained for monetary aggregates and interest rates. 
Moolman evaluates the optimal lead duration for each financial variable via the socalled "pseudo R-squared” (2003: 296-297). Table 55 presents the lead intervals suggested by both the concordance analysis and the probit models.

Table 55:

Lead intervals suggested by concordance statistic (this study) and probit model (Moolman (2003))

\begin{tabular}{|c|c|c|c|c|c|c|c|c|c|}
\hline \multirow{2}{*}{ Financial variable } & \multicolumn{7}{|c|}{ Lead interval (in months) } \\
\hline & $\mathbf{1 - 3}$ & $\mathbf{2 - 4}$ & $\mathbf{3 - 5}$ & $\mathbf{4 - 6}$ & $\mathbf{6}$ & $\mathbf{9}$ & $\mathbf{1 2}$ & $\mathbf{1 5}$ & $\mathbf{1 8}$ \\
\hline Real M3 & CONC & & & & & & & & PROB \\
\hline 3-m T-Bill yield & CONC & & & & PROB & & & & \\
\hline $\begin{array}{c}\text { 3-m T-Bill yield } \\
\text { (real) }\end{array}$ & CONC & & & & PROB & & & & \\
\hline $\begin{array}{c}\text { 10-yr Govt Bond } \\
\text { yield (real) }\end{array}$ & CONC & & PROB & & & & & & \\
\hline $\begin{array}{c}\text { JSE Resources } \\
\text { Index }\end{array}$ & & & & & $\begin{array}{c}\text { CONC } \\
\text { PROB }\end{array}$ & & & & \\
\hline \begin{tabular}{c} 
Yield curve \\
\hline
\end{tabular} & & & & PROB & CONC & & & \\
\hline
\end{tabular}

Source: Probit results from Moolman (2003)

As far as short-term interest rates and the real M3 money supply are concerned, the concordance statistic consistently finds much shorter lead intervals compared to those suggested by the probit models. The difference in the case of long-term real interest rates is less accentuated. As discussed, the divergence in results can be explained by the difference in sample periods, as the longer sample period of Moolman (2003) includes several monetary policy regimes. In contrast, the results are identical for the JSE Resources Index (called 'Mining Shares Index' by Moolman (2003: 295)). Also, lead duration for the yield curve is quite similar - nine months based on the concordance study and seven months (classified as six in the table) using the probit model.

The analogy can be extended by comparing which two financial variables each of the approaches identify as superior in forecasting business cycle turns. In the probit models, the "pseudo R-squared" suggests that the yield curve and nominal short-term interest rate have superior forecasting capacity relative to the other financial variables. The p-values from the regression tests, assessing the significance of the concordance statistic, identify the nominal and real short-term interest rates. Hence, the 
econometric and traditional (i.e. concordance) approaches agree on one of the two variables.

The preceding comparison, as well as the comparison attempts of Sections 4.7 and 5.5 , reiterates that conclusions about leading indicator behaviour of financial variables depend, firstly, on the weights assigned to each of the conformity and lead interval criteria respectively and, secondly, on the sample period considered. Nonetheless this study has argued that the model-free approach, as applied to the period 1986-2004, is the most appropriate technique for evaluation of financial variables as leading indicators in South Africa. How then should the results of this study be interpreted?

\subsection{Final Conclusions}

The observations of this study suggest interpretations from three (related) perspectives: a conceptual perspective, a business cycle forecasting perspective, and a perspective related to the monetary transmission mechanism.

From a conceptual perspective this study reiterates the call by Harding and Pagan (2005) for definitions in business cycle analysis that are transparent and are consistent with the business cycle views held by economists in the public and private sectors. It has applied the traditional approach pioneered by Burns and Mitchell (1946) to the description of cyclical features in financial variables and real economic activity in South Africa. The study has presented a set of pre-determined rules that can be reproduced in the identification of turning points in financial variables as well as in the matching of these turning points with corresponding business cycle peaks and troughs. In addition, the study has introduced the use of the concordance statistic (Harding and Pagan 2001) and the lead profile (Banerji 1999a) as statistical tests in the evaluation of leading indicators.

The conclusions from a forecasting perspective are perhaps the most salient. It is evident from the previous chapter that there are few financial variables that meet the requirements of an exact match between the number of turning points in the financial variable and the number of business cycle turning points. Moreover, such financial variables do not display the required stability in their lead-duration. On the other 
hand, even if the economist can endure the possibility of false signals (that is, of imperfect matching) for cases that $d o$ exhibit sufficiently stable lead intervals, these periods rarely exceed three months. This is problematic considering the window width of six months required in identifying peaks in particular series, although advances in real-time turning point forecasting could ameliorate this problem (see Chauvet and Hamilton (2005)). In general, though, the above observations serve to dismiss the ideal of turning point forecasting for the South African business cycle based on single leading indicators. Hence, multivariate leading indicator frameworks ${ }^{26}$, such as those employed by the South African Reserve Bank, other central banks as well as the Economic Cycle Research Institute, will potentially minimize turning point forecasting errors.

This dissertation also offers alternative evidence on the nature of the relationship between the financial and real sectors of the South African economy. And, by implication, it also investigates the monetary transmission mechanism, in an elementary manner, similar to the methods employed by Friedman and Schwartz (1963) in their classic study of the relationship between money and business cycles in the United States. While certainly not as elaborate as the Friedman and Schwartz study, it does support the well-established result that money (and more broadly, financial markets) matter for the cycle of economic activity. The concordance statistic shows that cycles in monetary aggregates, as well as local and international interest and exchange rates lead the business cycle at statistically significant levels ${ }^{27}$.

Beyond these interpretations, the results also recommend the following two aspects for further investigation:

\footnotetext{
${ }^{26}$ It is perhaps worth noting that the proposed multivariate approach does not imply the construction of a single "financial cycle" leading indicator - a concept that lacks intuitive economic meaning (see Dudley and Hatzius (2000)). In contrast, the multivariate approach referred to here is consistent with the approach by Achuthan and Banerji (2004). The latter entails a scrutiny of turning point signals from a range of leading indicators via the diffusion index, which shows the proportion of series expanding or contracting (see the discussion by Venter (2005) on the use of diffusion indices at the SARB).

${ }^{27}$ This "correlation" is, of course, not sufficient as a causal argument.
} 
(i) An investigation into the real-time identification of turning points in economic time series via the non-linear parametric method proposed by Chauvet and Hamilton (2005). This allows turning point identification without the implied waiting period needed to establish a window width of two quarters around a turning point. This method could be important in identifying turning points in relatively stable financial leading indicators.

(ii) An analysis of the impact of different growth rate cycle concepts. In particular, the sensitivity of the growth rate findings when the so-called sixmonth smoothed annualised rate (SMSAR) is used, instead of a conventional six- or twelve-month growth rate (see Banerji 1999b).

A comment in 1703 by Gottfried von Leibniz to the Swiss mathematician Jacob Bernoulli could have been written just as well by any sensible business cycle analyst: "[N]ature has established patterns originating in the return of events, but only for the most part" (Bernstein 1998: 7; my emphasis). The approach most appropriate for an analysis of cyclicality is one that allows for sufficient individuality in each cycle, while facilitating an explanation of systematic relationships. The model-free approach, as employed in this study, answers both of these criteria. Its application to financial variables in South Africa yields sobering results - and trumpets an old warning to economists who seek to forecast and theorize prior to a thorough descriptive analysis of the data. 
APPENDIX C:

CHRONOLOGY OF CYCLES IN SOUTH AFRICAN REAL ECONOMIC ACTIVITY

\begin{tabular}{|c|c|c|c|c|}
\hline Quarter & $\begin{array}{l}\text { Official SARB } \\
\text { Business cycle }\end{array}$ & $\begin{array}{c}\text { GDP } \\
\text { Gr. rate cycle }\end{array}$ & $\begin{array}{l}\text { Industr. Prod. } \\
\text { Classical cycle }\end{array}$ & $\begin{array}{l}\text { Industr. Prod. } \\
\text { Gr. rate cycle }\end{array}$ \\
\hline 1986Q1 & $\mathrm{T}$ & & $\mathrm{T}$ & \\
\hline \multicolumn{5}{|l|}{ 1986Q2 } \\
\hline 1986Q3 & & & & $\mathrm{P}$ \\
\hline 1986Q4 & & & $\mathrm{P}$ & \\
\hline \multicolumn{5}{|l|}{ 1987Q1 } \\
\hline 1987Q2 & & & $\mathrm{T}$ & $\mathrm{T}$ \\
\hline \multicolumn{5}{|l|}{ 1987Q3 } \\
\hline \multicolumn{5}{|l|}{ 1987Q4 } \\
\hline \multicolumn{5}{|l|}{ 1988Q1 } \\
\hline \multicolumn{5}{|l|}{ 1988Q2 } \\
\hline 1988Q3 & & $P$ & & $P$ \\
\hline \multicolumn{5}{|l|}{ 1988Q4 } \\
\hline 1989Q1 & $\mathrm{P}$ & & $\mathrm{P}$ & \\
\hline \multicolumn{5}{|l|}{ 1989Q2 } \\
\hline \multicolumn{5}{|l|}{ 1989Q3 } \\
\hline \multicolumn{5}{|l|}{ 1989Q4 } \\
\hline 1990Q1 & & & & $\mathrm{T}$ \\
\hline 1990Q2 & & $y$ & & \\
\hline 1990Q3 & & 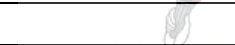 & & $\mathrm{P}$ \\
\hline 1991Q4 & & 20 & & \\
\hline 1991Q1 & & 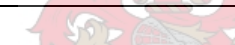 & & \\
\hline 1991Q2 & & $x^{2}=x$ & & \\
\hline 1991Q3 & & 78 & & \\
\hline \multicolumn{5}{|l|}{ 1991Q4 } \\
\hline \multicolumn{5}{|l|}{ 1992Q1 } \\
\hline \multicolumn{5}{|c|}{ 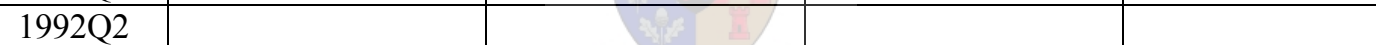 } \\
\hline 1992Q3 & & $6>>1$ & $\mathrm{~T}$ & $\mathrm{~T}$ \\
\hline \multirow{2}{*}{\multicolumn{5}{|c|}{$\frac{1992 Q 4}{1993 Q 1}$}} \\
\hline & & & & \\
\hline \multicolumn{5}{|l|}{ 1993Q2 } \\
\hline 1993Q3 & & & & $\mathrm{P}$ \\
\hline \multirow{2}{*}{\multicolumn{5}{|c|}{$\frac{1993 \mathrm{Q} 4}{1994 \mathrm{O} 1}$}} \\
\hline & & & & \\
\hline \multicolumn{4}{|l|}{ 1994Q2 } & $\mathrm{T}$ \\
\hline 1994Q3 & & $\mathrm{T}$ & & \\
\hline \multicolumn{5}{|l|}{ 1994Q4 } \\
\hline 1995Q1 & & $P$ & $P$ & \\
\hline 1995Q2 & & & & $\mathrm{P}$ \\
\hline \multicolumn{5}{|l|}{ 1995Q3 } \\
\hline 1995Q4 & & $\mathrm{T}$ & $\mathrm{T}$ & \\
\hline 1996Q1 & & & & $\mathrm{T}$ \\
\hline \multicolumn{5}{|l|}{ 1996Q2 } \\
\hline \multicolumn{5}{|l|}{ 1996Q3 } \\
\hline 1996Q4 & $\mathrm{P}$ & $\mathrm{P}$ & & \\
\hline 1997Q1 & & & & $\mathrm{P}$ \\
\hline 1997Q2 & & & $P$ & \\
\hline 1997Q3 & & & & \\
\hline 1997Q4 & & & & \\
\hline 1998Q1 & & & & \\
\hline 1998Q2 & & & & \\
\hline 1998Q3 & & & & \\
\hline
\end{tabular}




\begin{tabular}{|c|c|c|c|c|}
\hline Quarter & $\begin{array}{l}\text { Official SARB } \\
\text { Business cycle }\end{array}$ & $\begin{array}{c}\text { GDP } \\
\text { Gr. rate cycle }\end{array}$ & $\begin{array}{l}\text { Industr. Prod. } \\
\text { Classical cycle }\end{array}$ & $\begin{array}{l}\text { Industr. Prod. } \\
\text { Gr. rate cycle }\end{array}$ \\
\hline 1998Q4 & & $\mathrm{T}$ & $\mathrm{T}$ & $\mathrm{T}$ \\
\hline \multicolumn{5}{|l|}{ 1999Q1 } \\
\hline \multicolumn{5}{|l|}{ 1999Q2 } \\
\hline 1999Q3 & $\mathrm{T}$ & & & \\
\hline \multicolumn{5}{|l|}{ 1999Q4 } \\
\hline \multicolumn{5}{|l|}{ 2000Q1 } \\
\hline 2000Q2 & & $\mathrm{P}$ & & $\mathrm{P}$ \\
\hline \multicolumn{5}{|l|}{ 2000Q3 } \\
\hline \multicolumn{5}{|l|}{$2000 \mathrm{Q} 4$} \\
\hline \multicolumn{5}{|l|}{ 2001Q1 } \\
\hline \multicolumn{5}{|l|}{$2001 \mathrm{Q} 2$} \\
\hline 2001Q3 & & & & $\mathrm{T}$ \\
\hline $2001 Q 4$ & & $\mathrm{~T}$ & & \\
\hline \multicolumn{5}{|l|}{ 2002Q1 } \\
\hline 2002Q2 & & & $\mathrm{P}$ & $\mathrm{P}$ \\
\hline \multicolumn{5}{|l|}{ 2002Q3 } \\
\hline $2002 Q 4$ & & $\mathrm{P}$ & & \\
\hline \multicolumn{5}{|l|}{ 2003Q1 } \\
\hline $2003 \mathrm{Q} 2$ & & & $\mathrm{~T}$ & $\mathrm{~T}$ \\
\hline \multicolumn{5}{|l|}{$2003 \mathrm{Q} 3$} \\
\hline $2003 Q 4$ & & $\mathrm{~T}$ & & \\
\hline \multicolumn{5}{|l|}{ 2004Q1 } \\
\hline 2004Q2 & & 7 & & \\
\hline $2004 \mathrm{Q} 3$ & & $(4)$ & & \\
\hline $2004 Q 4$ & & then कes & & \\
\hline
\end{tabular}




\section{APPENDIX D: EVALUATION OF BUSINESS CYCLE CONFORMITY}

Table 22:

Concordance of monetary variables and real economic activity

\begin{tabular}{|c|c|c|c|c|c|c|c|c|c|c|c|c|}
\hline \multirow{2}{*}{$\begin{array}{l}\text { Financial } \\
\text { Variable }\end{array}$} & \multirow{2}{*}{$\begin{array}{l}\text { Real Economic } \\
\text { Activity }\end{array}$} & \multicolumn{11}{|c|}{ Concordance (mean-corrected and re-scaled) } \\
\hline & & $\mathbf{0}$ & 1 & 2 & 3 & 4 & 5 & 6 & 9 & 12 & 15 & 18 \\
\hline Real M1 & SARB Cycle & 0.00 & -0.02 & -0.05 & -0.08 & -0.10 & -0.12 & -0.14 & -0.23 & -0.29 & -0.31 & -0.30 \\
\hline Real M1 & GDP Growth & -0.14 & -0.15 & -0.15 & -0.16 & -0.14 & -0.11 & -0.05 & 0.01 & -0.04 & -0.13 & -0.30 \\
\hline Real M3 & SARB Cycle & $0.35^{*}$ & $0.32^{*}$ & $0.29^{*}$ & $0.26^{*}$ & $0.23^{*}$ & $0.21^{*}$ & $0.19^{*}$ & $0.07^{*}$ & $-0.05^{*}$ & $-0.15^{*}$ & $-0.22^{*}$ \\
\hline Real M3 & GDP Growth & -0.07 & -0.07 & -0.08 & -0.08 & -0.08 & -0.09 & -0.07 & -0.07 & -0.08 & -0.14 & -0.19 \\
\hline Real M1 & Ind Prod & 0.04 & 0.00 & -0.02 & 0.04 & -0.04 & -0.02 & -0.01 & -0.03 & -0.12 & -0.21 & -0.29 \\
\hline Real M1 & Ind Prod Growth & $-0.17^{*}$ & $-0.16^{*}$ & $-0.13^{*}$ & $-0.08^{*}$ & $-0.03^{*}$ & $0.00^{*}$ & $0.02^{*}$ & $0.08^{*}$ & $0.07^{*}$ & $-0.09^{*}$ & $-0.22^{*}$ \\
\hline Real M3 & Ind Prod & $0.38^{* *}$ & $0.33^{* *}$ & $0.28^{* *}$ & $0.22^{* *}$ & $0.18^{* *}$ & $0.14^{* *}$ & $0.08^{* *}$ & $-0.04^{* *}$ & $-0.17^{* *}$ & $-0.27^{* *}$ & $-0.35^{* *}$ \\
\hline Real M3 & Ind Prod Growth & -0.07 & -0.06 & -0.03 & 0.00 & 0.04 & 0.07 & 0.09 & 0.06 & -0.02 & -0.05 & -0.09 \\
\hline
\end{tabular}

* Significant at $25 \% * *$ Significant at $15 \% * * *$ Significant at $5 \%$ 
Table 23:

Concordance of local nominal interest rates and real economic activity

\begin{tabular}{|c|c|c|c|c|c|c|c|c|c|c|c|c|}
\hline \multirow{2}{*}{$\begin{array}{l}\text { Financial } \\
\text { Variable }\end{array}$} & \multirow{2}{*}{$\begin{array}{l}\text { Real Economic } \\
\text { Activity }\end{array}$} & \multicolumn{11}{|c|}{ Concordance (mean-corrected and re-scaled) } \\
\hline & & $\mathbf{0}$ & 1 & 2 & 3 & 4 & 5 & 6 & 9 & 12 & 15 & 18 \\
\hline 3 month TB yield & SARB Cycle & $0.48^{* * *}$ & $0.44^{* * *}$ & $0.39^{* * *}$ & $0.34^{* * *}$ & $0.30^{* * *}$ & $0.27^{* * *}$ & $0.23^{* * *}$ & $0.11^{* * *}$ & $0.01^{* * *}$ & $-0.04^{* * *}$ & $-0.12^{* * *}$ \\
\hline 3 month TB yield & GDP Growth & 0.20 & 0.16 & 0.10 & 0.04 & 0.00 & -0.02 & -0.04 & -0.13 & -0.20 & -0.15 & -0.08 \\
\hline 12 month NCD rate & SARB Cycle & $0.29^{* *}$ & $0.25^{* *}$ & $0.22^{* *}$ & $0.18^{* *}$ & $0.15^{* *}$ & $0.12^{* *}$ & $0.09^{* *}$ & $-0.03^{* *}$ & $-0.08^{* *}$ & $-0.08^{* *}$ & $-0.14^{* *}$ \\
\hline 12 month NCD rate & GDP Growth & $0.25^{*}$ & $0.25^{*}$ & $0.22^{*}$ & $0.17^{*}$ & $0.14^{*}$ & $0.11^{*}$ & $0.08^{*}$ & $-0.03^{*}$ & $-0.18^{*}$ & $-0.22^{*}$ & $-0.15^{*}$ \\
\hline 10 year bond yield & SARB Cycle & 0.04 & 0.01 & 0.00 & -0.01 & -0.01 & -0.02 & -0.02 & -0.13 & -0.20 & -0.21 & -0.25 \\
\hline 10 year bond yield & GDP Growth & 0.10 & 0.15 & 0.18 & 0.16 & 0.16 & 0.15 & 0.15 & 0.04 & -0.22 & -0.30 & -0.22 \\
\hline 3 month TB yield & Ind Prod & 0.15 & 0.12 & 0.10 & 0.09 & 0.09 & 0.09 & 0.07 & 0.04 & -0.05 & -0.16 & -0.23 \\
\hline 3 month TB yield & Ind Prod Growth & -0.02 & -0.02 & -0.02 & -0.05 & -0.05 & -0.05 & -0.06 & -0.03 & -0.02 & -0.04 & 0.02 \\
\hline 12 month NCD rate & Ind Prod & 0.13 & 0.10 & 0.06 & 0.02 & 0.01 & -0.03 & -0.06 & -0.12 & -0.21 & -0.27 & -0.24 \\
\hline 12 month NCD rate & Ind Prod Growth & 0.14 & 0.13 & 0.11 & 0.10 & 0.09 & 0.04 & -0.01 & -0.10 & -0.14 & -0.10 & 0.01 \\
\hline 10 year bond yield & Ind Prod & 0.04 & 0.01 & 0.00 & -0.03 & -0.04 & -0.06 & -0.08 & -0.13 & -0.23 & -0.30 & -0.21 \\
\hline 10 year bond yield & Ind Prod Growth & 0.28 & 0.29 & 0.29 & 0.27 & 0.25 & 0.17 & 0.10 & -0.12 & -0.31 & -0.32 & -0.11 \\
\hline
\end{tabular}

$*$ Significant at $25 \% * *$ Significant at $15 \% * * *$ Significant at $5 \%$ 
Table 24:

Concordance of local real interest rates and real economic activity

\begin{tabular}{|c|c|c|c|c|c|c|c|c|c|c|c|c|}
\hline \multirow{2}{*}{$\begin{array}{l}\text { Financial } \\
\text { Variable }\end{array}$} & \multirow{2}{*}{$\begin{array}{l}\text { Real Economic } \\
\text { Activity }\end{array}$} & \multicolumn{11}{|c|}{ Concordance (mean-corrected and re-scaled) } \\
\hline & & $\mathbf{0}$ & 1 & 2 & 3 & 4 & 5 & 6 & 9 & 12 & 15 & 18 \\
\hline Real 3m TB yield & SARB Cycle & $0.34^{* *}$ & $0.34^{* *}$ & $0.34^{* *}$ & $0.32^{* *}$ & $0.31^{* *}$ & $0.29^{* *}$ & $0.28^{* *}$ & $0.21^{* *}$ & $0.11^{* *}$ & $0.07^{* *}$ & $0.00^{* *}$ \\
\hline Real 3m TB yield & GDP Growth & 0.15 & 0.10 & 0.07 & 0.03 & 0.00 & -0.03 & -0.06 & -0.10 & -0.06 & 0.07 & 0.13 \\
\hline Real $12 \mathrm{~m}$ NCDrate & SARB Cycle & 0.17 & 0.20 & 0.23 & 0.25 & 0.27 & 0.28 & 0.28 & 0.23 & 0.12 & 0.06 & -0.01 \\
\hline Real $12 \mathrm{~m}$ NCDrate & GDP Growth & -0.06 & 0.00 & 0.05 & 0.11 & 0.17 & 0.21 & 0.25 & 0.27 & 0.19 & 0.07 & 0.02 \\
\hline Real 10 yr b yield & SARB Cycle & $0.32^{*}$ & $0.33^{*}$ & $0.34^{*}$ & $0.34^{*}$ & $0.33^{*}$ & $0.32^{*}$ & $0.29^{*}$ & $0.16^{*}$ & $0.05^{*}$ & $-0.05^{*}$ & $-0.07^{*}$ \\
\hline Real 10 yr b yield & GDP Growth & -0.10 & -0.10 & -0.08 & -0.08 & -0.10 & -0.11 & -0.09 & 0.03 & 0.22 & 0.25 & 0.29 \\
\hline Real 3m TB yield & Ind Prod & -0.03 & -0.08 & -0.08 & -0.09 & -0.05 & -0.01 & 0.03 & 0.13 & 0.16 & 0.10 & -0.08 \\
\hline Real 3m TB yield & Ind Prod Growth & $-0.22^{*}$ & $-0.27^{*}$ & $-0.29^{*}$ & $-0.28^{*}$ & $-0.26^{*}$ & $-0.21^{*}$ & $-0.15^{*}$ & $0.01^{*}$ & $0.16^{*}$ & $0.24^{*}$ & $0.16^{*}$ \\
\hline Real $12 \mathrm{~m}$ NCDrate & Ind Prod & 0.12 & 0.13 & 0.15 & 0.16 & 0.20 & 0.24 & 0.25 & 0.23 & 0.13 & -0.03 & -0.08 \\
\hline Real $12 \mathrm{~m}$ NCDrate & Ind Prod Growth & 0.07 & 0.14 & 0.22 & 0.30 & 0.36 & 0.42 & 0.44 & 0.37 & 0.07 & -0.14 & -0.16 \\
\hline Real 10 yr b yield & Ind Prod & 0.20 & 0.17 & 0.14 & 0.10 & 0.07 & 0.05 & 0.04 & 0.05 & 0.16 & 0.30 & 0.36 \\
\hline Real 10 yr b yield & Ind Prod Growth & 0.09 & -0.01 & -0.12 & -0.19 & -0.24 & -0.28 & -0.26 & -0.11 & 0.02 & 0.12 & 0.18 \\
\hline
\end{tabular}

* Significant at $25 \% * *$ Significant at $15 \% * * *$ Significant at $5 \%$ 
Table 25:

Concordance of local JSE stock market indices (in levels) and real economic activity

\begin{tabular}{|c|c|c|c|c|c|c|c|c|c|c|c|c|}
\hline \multirow{2}{*}{$\begin{array}{l}\text { Financial } \\
\text { Variable }\end{array}$} & \multirow{2}{*}{$\begin{array}{l}\text { Real Economic } \\
\text { Activity }\end{array}$} & \multicolumn{11}{|c|}{ Concordance (mean-corrected and re-scaled) } \\
\hline & & $\mathbf{0}$ & 1 & 2 & 3 & 4 & 5 & 6 & 9 & 12 & 15 & 18 \\
\hline All Shares & SARB Cycle & 0.04 & 0.04 & 0.05 & 0.05 & 0.05 & 0.04 & 0.04 & 0.04 & -0.08 & -0.08 & -0.05 \\
\hline All Shares & GDP Growth & 0.07 & 0.09 & 0.12 & 0.15 & 0.15 & 0.15 & 0.13 & 0.13 & 0.01 & -0.14 & -0.11 \\
\hline Fin \& Industrial & SARB Cycle & -0.11 & -0.10 & -0.08 & -0.07 & -0.05 & -0.04 & -0.02 & 0.01 & -0.07 & -0.08 & -0.07 \\
\hline Fin \& Industrial & GDP Growth & 0.00 & 0.05 & 0.10 & 0.13 & 0.13 & 0.13 & 0.11 & 0.13 & 0.05 & -0.06 & -0.07 \\
\hline Resources & SARB Cycle & $0.30^{*}$ & $0.33^{*}$ & $0.35^{*}$ & $0.38^{*}$ & $0.40^{*}$ & $0.41^{*}$ & $0.43^{*}$ & $0.43^{*}$ & $0.30^{*}$ & $0.30^{*}$ & $0.29^{*}$ \\
\hline Resources & GDP Growth & 0.12 & 0.17 & 0.20 & 0.23 & 0.27 & 0.30 & 0.33 & 0.36 & 0.21 & 0.04 & -0.09 \\
\hline All Shares & Ind Prod & 0.18 & 0.16 & 0.12 & 0.11 & 0.09 & 0.06 & 0.04 & 0.06 & -0.03 & 0.00 & -0.01 \\
\hline All Shares & Ind Prod Growth & 0.00 & -0.04 & -0.07 & -0.09 & -0.11 & -0.13 & -0.15 & -0.11 & 0.07 & 0.16 & 0.06 \\
\hline Fin \& Industrial & Ind Prod & 0.01 & 0.01 & 0.00 & -0.02 & -0.05 & -0.06 & -0.08 & -0.07 & -0.04 & 0.11 & 0.19 \\
\hline Fin \& Industrial & Ind Prod Growth & -0.02 & -0.01 & -0.03 & -0.03 & -0.02 & -0.03 & -0.05 & 0.01 & 0.12 & 0.15 & 0.10 \\
\hline Resources & Ind Prod & $0.33^{* *}$ & $0.35^{* *}$ & $0.34^{* *}$ & $0.35^{* *}$ & $0.35^{* *}$ & $0.34^{* *}$ & $0.34^{* *}$ & $0.35^{* *}$ & $0.17^{* *}$ & $0.06^{* *}$ & $-0.01^{* *}$ \\
\hline Resources & Ind Prod Growth & 0.10 & 0.14 & 0.13 & 0.15 & 0.15 & 0.15 & 0.14 & 0.18 & 0.16 & 0.04 & -0.06 \\
\hline
\end{tabular}

* Significant at $25 \% * *$ Significant at $15 \% * * *$ Significant at 5\% 
Table 26:

Concordance of local JSE stock market yields (in levels) and real economic activity

\begin{tabular}{|c|c|c|c|c|c|c|c|c|c|c|c|c|}
\hline \multirow{2}{*}{$\begin{array}{l}\text { Financial } \\
\text { Variable }\end{array}$} & \multirow{2}{*}{$\begin{array}{l}\text { Real Economic } \\
\text { Activity }\end{array}$} & \multicolumn{11}{|c|}{ Concordance (mean-corrected and re-scaled) } \\
\hline & & $\mathbf{0}$ & 1 & 2 & 3 & 4 & 5 & 6 & 9 & 12 & 15 & 18 \\
\hline ALSI Div Yield & SARB Cycle & -0.01 & -0.05 & -0.08 & -0.12 & -0.14 & -0.17 & -0.21 & -0.24 & -0.33 & -0.29 & -0.27 \\
\hline ALSI Div Yield & GDP Growth & -0.12 & -0.17 & -0.21 & -0.24 & -0.25 & -0.25 & -0.24 & -0.20 & -0.16 & -0.08 & -0.04 \\
\hline ALSI P:E Ratio & SARB Cycle & -0.26 & -0.24 & -0.22 & -0.18 & -0.14 & -0.11 & -0.08 & 0.02 & 0.12 & 0.17 & 0.25 \\
\hline ALSI P:E Ratio & GDP Growth & 0.01 & 0.06 & 0.13 & 0.19 & 0.23 & 0.26 & 0.27 & 0.26 & 0.17 & 0.02 & -0.07 \\
\hline ALSI Div Yield & Ind Prod & -0.03 & -0.05 & -0.06 & -0.08 & -0.06 & -0.07 & -0.07 & -0.07 & -0.23 & -0.34 & -0.34 \\
\hline ALSI Div Yield & Ind Prod Growth & 0.00 & 0.03 & 0.05 & 0.06 & 0.06 & 0.05 & 0.05 & 0.02 & -0.16 & -0.23 & -0.21 \\
\hline ALSI P:E Ratio & Ind Prod & -0.03 & -0.01 & 0.00 & 0.02 & 0.04 & 0.05 & 0.07 & 0.16 & 0.17 & 0.19 & 0.30 \\
\hline ALSI P:E Ratio & Ind Prod Growth & 0.21 & 0.26 & 0.28 & 0.29 & 0.29 & 0.29 & 0.26 & 0.18 & 0.03 & -0.10 & -0.19 \\
\hline
\end{tabular}

* Significant at $25 \% * *$ Significant at $15 \% * * *$ Significant at $5 \%$ 
Table 27:

Concordance of local spreads (in levels) and real economic activity

\begin{tabular}{|c|c|c|c|c|c|c|c|c|c|c|c|c|}
\hline \multirow{2}{*}{$\begin{array}{l}\text { Financial } \\
\text { Variable }\end{array}$} & \multirow{2}{*}{$\begin{array}{l}\text { Real Economic } \\
\text { Activity }\end{array}$} & \multicolumn{11}{|c|}{ Concordance (mean-corrected and re-scaled) } \\
\hline & & $\mathbf{0}$ & 1 & 2 & 3 & 4 & 5 & 6 & 9 & 12 & 15 & 18 \\
\hline Yield Curve & SARB Cycle & $-0.28^{*}$ & $-0.31^{*}$ & $-0.33^{*}$ & $-0.36^{*}$ & $-0.38^{*}$ & $-0.42^{*}$ & $-0.46^{*}$ & $-0.57^{*}$ & $-0.57^{*}$ & $-0.54^{*}$ & $-0.41^{*}$ \\
\hline Yield Curve & GDP Growth & -0.09 & -0.15 & -0.21 & -0.27 & -0.31 & -0.31 & -0.32 & -0.24 & -0.26 & -0.25 & -0.24 \\
\hline Rev Yield Gap & SARB Cycle & -0.06 & -0.07 & -0.08 & -0.09 & -0.10 & -0.10 & -0.11 & -0.09 & -0.18 & -0.17 & -0.07 \\
\hline Rev Yield Gap & GDP Growth & -0.08 & -0.04 & 0.01 & 0.04 & 0.05 & 0.07 & 0.08 & 0.07 & -0.07 & -0.14 & -0.08 \\
\hline Real Rev Y Gap & SARB Cycle & -0.03 & -0.02 & 0.00 & 0.01 & 0.01 & 0.04 & 0.06 & 0.07 & 0.00 & -0.07 & -0.08 \\
\hline Real Rev Y Gap & GDP Growth & -0.23 & -0.18 & -0.12 & -0.06 & 0.00 & 0.06 & 0.12 & 0.27 & 0.21 & 0.03 & -0.12 \\
\hline Yield Curve & Ind Prod & -0.11 & -0.16 & -0.20 & -0.25 & -0.27 & -0.29 & -0.32 & -0.39 & -0.44 & -0.44 & -0.37 \\
\hline Yield Curve & Ind Prod Growth & 0.16 & 0.06 & 0.00 & -0.04 & -0.08 & -0.10 & -0.12 & -0.14 & -0.10 & -0.04 & -0.05 \\
\hline Rev Yield Gap & Ind Prod & -0.04 & -0.07 & -0.09 & -0.12 & -0.14 & -0.15 & -0.13 & -0.07 & -0.06 & -0.12 & -0.01 \\
\hline Rev Yield Gap & Ind Prod Growth & 0.10 & 0.13 & 0.14 & 0.14 & 0.11 & 0.09 & 0.07 & 0.05 & -0.05 & -0.07 & 0.03 \\
\hline Real Rev Y Gap & Ind Prod & -0.04 & -0.01 & 0.02 & 0.05 & 0.09 & 0.11 & 0.12 & 0.15 & 0.10 & 0.02 & 0.02 \\
\hline Real Rev Y Gap & Ind Prod Growth & 0.04 & 0.14 & 0.22 & 0.29 & 0.37 & 0.43 & 0.44 & 0.30 & -0.02 & -0.29 & -0.33 \\
\hline
\end{tabular}

* Significant at $25 \% * *$ Significant at $15 \% * * *$ Significant at 5\% 
Table 28:

Concordance of foreign exchange rates (in levels) and real economic activity

\begin{tabular}{|c|c|c|c|c|c|c|c|c|c|c|c|c|}
\hline \multirow{2}{*}{$\begin{array}{l}\text { Financial } \\
\text { Variable } \\
\end{array}$} & \multirow{2}{*}{$\begin{array}{l}\text { Real Economic } \\
\text { Activity }\end{array}$} & \multicolumn{11}{|c|}{ Concordance (mean-corrected and re-scaled) } \\
\hline & & $\mathbf{0}$ & 1 & 2 & 3 & 4 & 5 & 6 & 9 & 12 & 15 & 18 \\
\hline Real Eff Rand & SARB Cycle & -0.12 & -0.12 & -0.11 & -0.11 & -0.08 & -0.05 & -0.05 & 0.04 & 0.09 & 0.07 & 0.04 \\
\hline Real Eff Rand & GDP Growth & 0.10 & 0.11 & 0.14 & 0.16 & 0.21 & 0.27 & 0.25 & 0.22 & 0.17 & 0.02 & -0.19 \\
\hline Real R/\$ & SARB Cycle & 0.06 & 0.06 & 0.05 & 0.05 & 0.03 & 0.02 & 0.00 & -0.02 & -0.11 & -0.08 & -0.02 \\
\hline Real R/\$ & GDP Growth & -0.11 & -0.12 & -0.14 & -0.16 & -0.17 & -0.19 & -0.18 & -0.17 & -0.12 & -0.11 & -0.06 \\
\hline Real Eff Rand & Ind Prod & -0.13 & -0.10 & -0.07 & -0.05 & -0.02 & 0.01 & 0.02 & 0.11 & 0.21 & 0.31 & 0.26 \\
\hline Real Eff Rand & Ind Prod Growth & 0.00 & -0.04 & -0.05 & -0.05 & -0.03 & 0.01 & 0.05 & 0.13 & 0.12 & 0.11 & 0.04 \\
\hline Real R/\$ & Ind Prod & 0.22 & 0.20 & 0.18 & 0.16 & 0.14 & 0.15 & 0.13 & 0.11 & -0.04 & -0.18 & -0.22 \\
\hline Real R/\$ & Ind Prod Growth & -0.15 & -0.13 & -0.13 & -0.13 & -0.12 & -0.12 & -0.12 & -0.12 & -0.09 & -0.06 & 0.02 \\
\hline
\end{tabular}

* Significant at $25 \% * *$ Significant at $15 \% * * *$ Significant at $5 \%$ 
Table 29:

Concordance of international bond and stock markets variables (in levels) and real economic activity

\begin{tabular}{|c|c|c|c|c|c|c|c|c|c|c|c|c|}
\hline \multirow{2}{*}{$\begin{array}{l}\text { Financial } \\
\text { Variable }\end{array}$} & \multirow{2}{*}{$\begin{array}{l}\text { Real Economic } \\
\text { Activity }\end{array}$} & \multicolumn{11}{|c|}{ Concordance (mean-corrected and re-scaled) } \\
\hline & & $\mathbf{0}$ & 1 & 2 & 3 & 4 & 5 & 6 & 9 & 12 & 15 & 18 \\
\hline Fed Funds Rate & SARB Cycle & $0.18^{* *}$ & $0.18^{* *}$ & $0.19^{* *}$ & $0.20^{* *}$ & $0.21^{* *}$ & $0.22^{* *}$ & $0.22^{* *}$ & $0.22^{* *}$ & $0.11^{* *}$ & $0.09^{* *}$ & $0.10^{* *}$ \\
\hline Fed Funds Rate & GDP Growth & $0.40^{* * *}$ & $0.34^{* * *}$ & $0.29^{* * *}$ & $0.23^{* * *}$ & $0.17^{* * *}$ & $0.11^{* * *}$ & $0.05^{* * *}$ & $0.01^{* * *}$ & $-0.13^{* * *}$ & $-0.12^{* * *}$ & $-0.07^{* * *}$ \\
\hline US $10 y r$ bond & SARB Cycle & 0.10 & 0.09 & 0.08 & 0.07 & 0.07 & 0.06 & 0.06 & 0.07 & 0.04 & 0.02 & -0.03 \\
\hline US $10 y r$ bond & GDP Growth & $0.23^{*}$ & $0.24^{*}$ & $0.25^{*}$ & $0.27^{*}$ & $0.28^{*}$ & $0.27^{*}$ & $0.25^{*}$ & $0.21^{*}$ & $-0.03^{*}$ & $-0.18^{*}$ & $-0.29^{*}$ \\
\hline Int differential & SARB Cycle & 0.05 & 0.01 & -0.02 & -0.07 & -0.10 & -0.14 & -0.17 & -0.27 & -0.37 & -0.42 & -0.45 \\
\hline Int differential & GDP Growth & -0.18 & -0.21 & -0.25 & -0.28 & -0.29 & -0.31 & -0.32 & -0.33 & -0.28 & -0.19 & -0.18 \\
\hline MSCI EM Share & SARB Cycle & 0.01 & 0.01 & 0.01 & 0.01 & 0.01 & 0.00 & 0.00 & 0.00 & -0.01 & -0.08 & -0.15 \\
\hline MSCI EM Share & GDP Growth & $0.14^{*}$ & $0.15^{*}$ & $0.19^{*}$ & $0.22^{*}$ & $0.22^{*}$ & $0.20^{*}$ & $0.18^{*}$ & $0.07^{*}$ & $-0.10^{*}$ & $-0.31^{*}$ & $-0.36^{*}$ \\
\hline Fed Funds Rate & Ind Prod & $0.31^{* * *}$ & $0.28^{* * *}$ & $0.24^{* * *}$ & $0.21^{* * *}$ & $0.19^{* * *}$ & $0.17^{* * *}$ & $0.15^{* * *}$ & $0.16^{* * *}$ & $0.11^{* * *}$ & $0.10^{* * *}$ & $0.09^{* * *}$ \\
\hline Fed Funds Rate & Ind Prod Growth & $0.14^{* *}$ & $0.14^{* *}$ & $0.12^{* *}$ & $0.10^{* *}$ & $0.07^{* *}$ & $0.05^{* *}$ & $0.03^{* *}$ & $-0.02^{* *}$ & $-0.11^{* *}$ & $-0.05^{* *}$ & $0.01^{* *}$ \\
\hline US $10 \mathrm{yr}$ bond & Ind Prod & $0.27^{* *}$ & $0.28^{* *}$ & $0.29^{* *}$ & $0.28^{* *}$ & $0.27^{* *}$ & $0.25^{* *}$ & $0.23^{* *}$ & $0.20^{* *}$ & $-0.01^{* *}$ & $-0.10^{* *}$ & $-0.20^{* *}$ \\
\hline US $10 y r$ bond & Ind Prod Growth & $0.35^{* * *}$ & $0.40^{* * *}$ & $0.41^{* * *}$ & $0.43^{* * *}$ & $0.42^{* * *}$ & $0.42^{* * *}$ & $0.40^{* * *}$ & $0.31^{* * *}$ & $-0.09^{* * *}$ & $-0.32^{* * *}$ & $-0.44^{* * *}$ \\
\hline Int differential & Ind Prod & -0.21 & -0.25 & -0.30 & -0.32 & -0.34 & -0.35 & -0.37 & -0.38 & -0.39 & -0.43 & -0.44 \\
\hline Int differential & Ind Prod Growth & -0.08 & -0.10 & -0.13 & -0.14 & -0.16 & -0.17 & -0.19 & -0.19 & -0.18 & -0.14 & -0.04 \\
\hline MSCI EM Share & Ind Prod & 0.03 & 0.03 & 0.02 & 0.02 & 0.04 & 0.04 & 0.04 & 0.03 & -0.04 & -0.09 & -0.06 \\
\hline MSCI EM Share & Ind Prod Growth & 0.11 & 0.09 & 0.06 & 0.04 & 0.02 & 0.00 & -0.01 & -0.01 & 0.00 & -0.06 & -0.07 \\
\hline
\end{tabular}

* Significant at $25 \% * *$ Significant at $15 \% * * *$ Significant at $5 \%$ 
Table 30:

Concordance of twelve-month growth rates in monetary variables with real economic activity

\begin{tabular}{|c|c|c|c|c|c|c|c|c|c|c|c|c|}
\hline \multirow{2}{*}{$\begin{array}{l}\text { Financial } \\
\text { Variable } \\
\end{array}$} & \multirow{2}{*}{$\begin{array}{l}\text { Real Economic } \\
\text { Activity }\end{array}$} & \multicolumn{11}{|c|}{ Concordance (mean-corrected and re-scaled) } \\
\hline & & $\mathbf{0}$ & 1 & 2 & 3 & 4 & 5 & 6 & 9 & 12 & 15 & 18 \\
\hline Real M1 & SARB Cycle & -0.02 & 0.03 & 0.06 & 0.09 & 0.11 & 0.14 & 0.12 & 0.08 & -0.03 & -0.18 & -0.22 \\
\hline Real M1 & GDP Growth & -0.06 & -0.02 & 0.02 & 0.08 & 0.14 & 0.20 & 0.26 & 0.34 & 0.29 & 0.18 & 0.04 \\
\hline Real M3 & SARB Cycle & 0.10 & 0.12 & 0.13 & 0.13 & 0.16 & 0.18 & 0.16 & 0.09 & -0.11 & -0.21 & -0.17 \\
\hline Real M3 & GDP Growth & 0.02 & 0.01 & 0.03 & 0.06 & 0.11 & 0.14 & 0.17 & 0.27 & 0.20 & 0.04 & -0.09 \\
\hline Real M1 & Ind Prod & -0.02 & 0.03 & 0.08 & 0.09 & 0.12 & 0.16 & 0.20 & 0.17 & 0.10 & 0.02 & -0.02 \\
\hline Real M1 & Ind Prod Growth & -0.09 & -0.01 & 0.06 & 0.10 & 0.14 & 0.15 & 0.16 & 0.22 & 0.05 & -0.15 & -0.33 \\
\hline Real M3 & Ind Prod & $0.28^{* *}$ & $0.30^{* * *}$ & $0.32^{* *}$ & $0.35^{* *}$ & $0.35^{* *}$ & $0.33^{* *}$ & $0.31^{* *}$ & $0.30^{* *}$ & $0.20^{* *}$ & $0.10^{* * *}$ & $0.09^{* *}$ \\
\hline Real M3 & Ind Prod Growth & 0.11 & 0.14 & 0.18 & 0.17 & 0.19 & 0.17 & 0.16 & 0.13 & -0.02 & -0.23 & -0.26 \\
\hline
\end{tabular}

* Significant at $25 \% * *$ Significant at $15 \% * * *$ Significant at $5 \%$ 
Table 31:

Concordance of twelve-month growth rates in local stock market indices with real economic activity

\begin{tabular}{|c|c|c|c|c|c|c|c|c|c|c|c|c|}
\hline \multirow{2}{*}{$\begin{array}{l}\text { Financial } \\
\text { Variable }\end{array}$} & \multirow{2}{*}{$\begin{array}{l}\text { Real Economic } \\
\text { Activity }\end{array}$} & \multicolumn{11}{|c|}{ Concordance (mean-corrected and re-scaled) } \\
\hline & & $\mathbf{0}$ & 1 & 2 & 3 & 4 & 5 & 6 & 9 & 12 & 15 & 18 \\
\hline All Shares & SARB Cycle & 0.22 & 0.28 & 0.35 & 0.37 & 0.35 & 0.32 & 0.29 & 0.26 & 0.10 & 0.05 & -0.01 \\
\hline All Shares & GDP Growth & 0.03 & 0.11 & 0.18 & 0.26 & 0.32 & 0.36 & 0.39 & 0.39 & 0.19 & 0.04 & -0.03 \\
\hline Fin \& Industrial & SARB Cycle & 0.04 & 0.08 & 0.13 & 0.11 & 0.09 & 0.09 & 0.10 & 0.07 & -0.01 & 0.02 & 0.02 \\
\hline Fin \& Industrial & GDP Growth & -0.11 & -0.06 & 0.00 & 0.07 & 0.10 & 0.14 & 0.17 & 0.19 & 0.06 & -0.07 & 0.16 \\
\hline Resources & SARB Cycle & 0.08 & 0.18 & 0.26 & 0.30 & 0.31 & 0.32 & 0.33 & 0.33 & 0.24 & 0.11 & -0.06 \\
\hline Resources & GDP Growth & -0.15 & -0.06 & 0.02 & 0.10 & 0.16 & 0.23 & 0.27 & 0.29 & 0.24 & 0.09 & 0.03 \\
\hline All Shares & Ind Prod & 0.16 & 0.20 & 0.22 & 0.23 & 0.20 & 0.17 & 0.16 & 0.15 & 0.07 & 0.07 & 0.12 \\
\hline All Shares & Ind Prod Growth & -0.06 & -0.03 & -0.02 & -0.02 & 0.00 & 0.03 & 0.05 & 0.05 & 0.06 & 0.06 & 0.04 \\
\hline Fin \& Industrial & Ind Prod & -0.03 & 0.00 & -0.02 & -0.04 & -0.06 & -0.07 & -0.09 & -0.09 & 0.00 & 0.05 & 0.08 \\
\hline Fin \& Industrial & Ind Prod Growth & -0.20 & -0.17 & -0.17 & -0.17 & -0.12 & -0.08 & -0.04 & 0.03 & 0.23 & 0.23 & 0.16 \\
\hline Resources & Ind Prod & 0.01 & 0.06 & 0.09 & 0.11 & 0.12 & 0.15 & 0.17 & 0.21 & 0.19 & 0.08 & 0.05 \\
\hline Resources & Ind Prod Growth & -0.14 & -0.07 & 0.00 & 0.08 & 0.15 & 0.22 & 0.24 & 0.27 & 0.21 & 0.14 & 0.01 \\
\hline
\end{tabular}

* Significant at $25 \% * *$ Significant at $15 \% * * *$ Significant at $5 \%$ 
Table 32:

Concordance of twelve-month growth rates in foreign stock market indices with real economic activity

\begin{tabular}{|c|c|c|c|c|c|c|c|c|c|c|c|c|}
\hline \multirow{2}{*}{$\begin{array}{l}\text { Financial } \\
\text { Variable }\end{array}$} & \multirow{2}{*}{$\begin{array}{l}\text { Real Economic } \\
\text { Activity }\end{array}$} & \multicolumn{11}{|c|}{ Concordance (mean-corrected and re-scaled) } \\
\hline & & $\mathbf{0}$ & 1 & 2 & 3 & 4 & 5 & 6 & 9 & 12 & 15 & 18 \\
\hline S\&P 500 & SARB Cycle & -0.10 & -0.10 & -0.09 & -0.06 & -0.08 & -0.10 & -0.07 & -0.07 & 0.06 & 0.02 & -0.01 \\
\hline S\&P 500 & GDP Growth & -0.10 & -0.10 & -0.09 & -0.06 & -0.08 & -0.10 & -0.07 & -0.07 & 0.06 & 0.02 & -0.01 \\
\hline MSCI EMSI & SARB Cycle & -0.04 & 0.02 & 0.06 & 0.09 & 0.09 & 0.09 & 0.08 & 0.07 & 0.04 & -0.15 & -0.17 \\
\hline MSCI EMSI & GDP Growth & 0.00 & 0.04 & 0.08 & 0.09 & 0.11 & 0.11 & 0.10 & 0.10 & -0.03 & -0.15 & -0.25 \\
\hline JPM EMBI & SARB Cycle & 0.23 & 0.24 & 0.22 & 0.18 & 0.13 & 0.09 & 0.04 & 0.00 & 0.01 & -0.09 & -0.14 \\
\hline JPM EMBI & GDP Growth & $0.39^{* * *}$ & $0.34^{* * *}$ & $0.30^{* * *}$ & $0.28^{* * *}$ & $0.24^{* * *}$ & $0.17^{* * *}$ & $0.15^{* * *}$ & $0.12^{* * *}$ & $0.01^{* * *}$ & $-0.07^{* * *}$ & $-0.12^{* * *}$ \\
\hline S\&P 500 & Ind Prod & -0.09 & -0.07 & -0.06 & -0.11 & -0.17 & -0.22 & -0.25 & -0.26 & -0.10 & 0.02 & 0.14 \\
\hline S\&P 500 & Ind Prod Growth & 0.03 & -0.02 & -0.06 & -0.13 & -0.19 & -0.26 & -0.36 & -0.22 & 0.06 & 0.24 & 0.30 \\
\hline MSCI EMSI & Ind Prod & 0.09 & 0.12 & 0.12 & 0.09 & 0.07 & 0.02 & -0.03 & -0.09 & -0.25 & -0.32 & -0.33 \\
\hline MSCI EMSI & Ind Prod Growth & -0.02 & -0.01 & 0.01 & -0.02 & -0.05 & -0.05 & -0.06 & -0.06 & 0.01 & 0.04 & 0.02 \\
\hline JPM EMBI & Ind Prod & 0.05 & 0.09 & 0.10 & 0.11 & 0.12 & 0.13 & 0.13 & 0.16 & 0.29 & 0.31 & 0.30 \\
\hline JPM EMBI & Ind Prod Growth & 0.17 & 0.12 & 0.06 & -0.01 & -0.08 & -0.13 & -0.15 & -0.14 & 0.00 & 0.10 & 0.12 \\
\hline
\end{tabular}

* Significant at $25 \% * *$ Significant at $15 \% * * *$ Significant at 5\% 
Table 33:

Concordance of twelve-month growth rates in foreign exchange rates with real economic activity

\begin{tabular}{|c|c|c|c|c|c|c|c|c|c|c|c|c|}
\hline \multirow{2}{*}{$\begin{array}{l}\text { Financial } \\
\text { Variable } \\
\end{array}$} & \multirow{2}{*}{$\begin{array}{l}\text { Real Economic } \\
\text { Activity }\end{array}$} & \multicolumn{11}{|c|}{ Concordance (mean-corrected and re-scaled) } \\
\hline & & $\mathbf{0}$ & 1 & 2 & 3 & 4 & 5 & 6 & 9 & 12 & 15 & 18 \\
\hline Real Eff Rand & SARB Cycle & -0.10 & -0.11 & -0.09 & -0.07 & -0.06 & -0.04 & -0.02 & 0.03 & 0.04 & -0.04 & -0.17 \\
\hline Real Eff Rand & GDP Growth & -0.17 & -0.18 & -0.16 & -0.14 & -0.10 & -0.03 & 0.01 & 0.07 & 0.01 & -0.14 & -0.14 \\
\hline Real R/\$ & SARB Cycle & 0.38 & 0.40 & 0.41 & 0.42 & 0.40 & 0.37 & 0.35 & 0.34 & 0.16 & 0.06 & -0.02 \\
\hline Real R/\$ & GDP Growth & 0.23 & 0.25 & 0.26 & 0.28 & 0.28 & 0.27 & 0.27 & 0.28 & 0.12 & 0.04 & 0.09 \\
\hline Nominal R/\$ & SARB Cycle & 0.11 & 0.10 & 0.09 & 0.07 & 0.05 & 0.03 & 0.01 & 0.00 & -0.15 & -0.23 & -0.24 \\
\hline Nominal R/\$ & GDP Growth & 0.10 & 0.11 & 0.12 & 0.12 & 0.10 & 0.08 & 0.04 & 0.00 & -0.18 & -0.24 & -0.15 \\
\hline Real Eff Rand & Ind Prod & $-0.29^{*}$ & $-0.30^{*}$ & $-0.31^{*}$ & $-0.29^{*}$ & $-0.28^{*}$ & $-0.26^{*}$ & $-0.22^{*}$ & $-0.13^{*}$ & $-0.11^{*}$ & $-0.04^{*}$ & $0.03^{*}$ \\
\hline Real Eff Rand & Ind Prod Growth & -0.19 & -0.23 & -0.26 & -0.25 & -0.22 & -0.18 & -0.11 & 0.07 & 0.20 & 0.21 & 0.14 \\
\hline Real R/\$ & Ind Prod & $0.48^{* *}$ & $0.53^{* *}$ & $0.58^{* *}$ & $0.59^{* *}$ & $0.57^{* *}$ & $0.52^{* *}$ & $0.48^{* *}$ & $0.42^{* *}$ & $0.16^{* *}$ & $0.11^{* *}$ & $0.08^{* *}$ \\
\hline Real R/\$ & Ind Prod Growth & $0.42^{*}$ & $0.40^{*}$ & $0.37^{*}$ & $0.31^{*}$ & $0.24^{*}$ & $0.18^{*}$ & $0.09^{*}$ & $0.01^{*}$ & $-0.18^{*}$ & $-0.15^{*}$ & $0.04^{*}$ \\
\hline Nominal R/\$ & Ind Prod & $0.24^{*}$ & $0.27^{*}$ & $0.27^{*}$ & $0.28^{*}$ & $0.26^{*}$ & $0.20^{*}$ & $0.14^{*}$ & $0.08^{*}$ & $-0.15^{*}$ & $-0.19^{*}$ & $-0.20^{*}$ \\
\hline Nominal R/\$ & Ind Prod Growth & 0.15 & 0.13 & 0.09 & 0.04 & -0.02 & -0.08 & -0.16 & -0.23 & -0.34 & -0.27 & -0.08 \\
\hline
\end{tabular}

* Significant at $25 \% * *$ Significant at $15 \% * * *$ Significant at $5 \%$ 
Table 38:

\section{APPENDIX E: EVALUATION OF LEAD TIMES}

Cyclical timing of cycles in financial variables relative to the official SARB cycle

\begin{tabular}{|c|c|c|c|c|c|c|c|c|c|}
\hline \multirow[t]{3}{*}{ Financial variable } & \multirow{3}{*}{$\begin{array}{l}\text { Type of } \\
\text { cycle in } \\
\text { financial } \\
\text { variable }\end{array}$} & \multirow{3}{*}{$\begin{array}{l}\text { Number of } \\
\text { turns in } \\
\text { financial } \\
\text { variable } \\
\text { cycle }\end{array}$} & \multirow{3}{*}{$\begin{array}{l}\text { Number of } \\
\text { turns in } \\
\text { official } \\
\text { SARB cycle }\end{array}$} & \multirow{3}{*}{$\begin{array}{c}\text { Number of } \\
\text { turns in } \\
\text { official } \\
\text { SARB cycle } \\
\text { matched by } \\
\text { fin variable }\end{array}$} & \multicolumn{5}{|c|}{ Timing observations that are } \\
\hline & & & & & \multicolumn{2}{|c|}{ Leads } & \multirow{2}{*}{$\frac{\text { Coincident }}{\text { No. }}$} & \multicolumn{2}{|c|}{ Lags } \\
\hline & & & & & No. & Range & & No. & Range \\
\hline (1) & (2) & (3) & (4) & (5) & (6) & (7) & (8) & (9) & (10) \\
\hline $\begin{array}{l}\text { Real M3 } \\
\text { Peaks } \\
\text { Troughs } \\
\end{array}$ & Classical & $\begin{array}{l}4 \\
5 \\
\end{array}$ & $\begin{array}{l}2 \\
3 \\
\end{array}$ & $\begin{array}{l}2 \\
3 \\
\end{array}$ & - & $\begin{array}{c}- \\
\{+6\}\end{array}$ & - & $\begin{array}{l}2 \\
2 \\
\end{array}$ & $\begin{array}{c}\{-11 ;-19\} \\
\{-17 ;-2\}\end{array}$ \\
\hline $\begin{array}{l}\text { 3-month Treasury bill yield } \\
\text { Peaks } \\
\text { Troughs }\end{array}$ & Classical & $\begin{array}{l}5 \\
6\end{array}$ & $\begin{array}{l}2 \\
3 \\
\end{array}$ & $\begin{array}{l}2 \\
3\end{array}$ & $\begin{array}{l}- \\
-\end{array}$ & $\begin{array}{l}- \\
-\end{array}$ & $\begin{array}{l}- \\
-\end{array}$ & $\begin{array}{l}2 \\
3\end{array}$ & $\begin{array}{c}\{-12 ;-2\} \\
\{-9 ;-10 ;-6\}\end{array}$ \\
\hline $\begin{array}{l}\text { Real 3-month Treasury bill } \\
\text { yield } \\
\text { Peaks } \\
\text { Troughs }\end{array}$ & Classical & $\begin{array}{l}6 \\
6\end{array}$ & $\begin{array}{l}2 \\
2\end{array}$ & $\begin{array}{l}2 \\
3\end{array}$ & $\begin{array}{l}1 \\
1\end{array}$ & $\begin{array}{l}\{+6\} \\
\{+1\}\end{array}$ & - & $\begin{array}{l}1 \\
2\end{array}$ & $\begin{array}{c}\{-9\} \\
\{-6 ;-9\}\end{array}$ \\
\hline $\begin{array}{l}\text { 12-month NCD rate } \\
\text { Peaks } \\
\text { Troughs }\end{array}$ & Classical & $\begin{array}{l}6 \\
6 \\
\end{array}$ & $\begin{array}{l}2 \\
2\end{array}$ & $\begin{array}{l}2 \\
2\end{array}$ & $\begin{array}{l}1 \\
-\end{array}$ & $\begin{array}{c}\{+1\} \\
-\end{array}$ & - & $\begin{array}{l}1 \\
2\end{array}$ & $\begin{array}{c}\{-9\} \\
\{-9 ;-8\}\end{array}$ \\
\hline $\begin{array}{l}\text { Real } 10 \text {-year govt bond yield } \\
\text { Peaks } \\
\text { Troughs }\end{array}$ & Classical & $\begin{array}{l}8 \\
8\end{array}$ & $\begin{array}{l}2 \\
2 \\
\end{array}$ & $\begin{array}{l}2 \\
3 \\
\end{array}$ & $\begin{array}{l}2 \\
1\end{array}$ & $\begin{array}{c}\{+2 ;+6\} \\
\{+6\}\end{array}$ & $\begin{array}{l}- \\
-\end{array}$ & - & $\{-6 ;-8\}$ \\
\hline $\begin{array}{l}\text { Yield curve } \\
\text { Peaks } \\
\text { Troughs }\end{array}$ & Classical & $\begin{array}{l}7 \\
6 \\
\end{array}$ & $\begin{array}{l}2 t \\
2 p\end{array}$ & $\begin{array}{l}2 \\
2 \\
\end{array}$ & $\begin{array}{l}1 \\
-\end{array}$ & $\begin{array}{c}\{+1\} \\
-\end{array}$ & $\begin{array}{l}- \\
-\end{array}$ & $\begin{array}{l}1 \\
2 \\
\end{array}$ & $\begin{array}{c}\{-9\} \\
\{-11 ;-9\}\end{array}$ \\
\hline $\begin{array}{l}\text { JSE Resources Index } \\
\text { Peaks } \\
\text { Troughs } \\
\end{array}$ & Classical & $\begin{array}{l}5 \\
5 \\
\end{array}$ & $\begin{array}{l}2 \\
2 \\
\end{array}$ & $\begin{array}{l}2 \\
2 \\
\end{array}$ & $\begin{array}{l}1 \\
2 \\
\end{array}$ & $\begin{array}{c}\{+6\} \\
\{+6 ;+19\} \\
\end{array}$ & $\begin{array}{l}- \\
-\end{array}$ & $\begin{array}{l}1 \\
- \\
\end{array}$ & $\begin{array}{c}\{-15\} \\
- \\
\end{array}$ \\
\hline $\begin{array}{l}\text { US Federal Funds rate } \\
\text { Peaks } \\
\text { Troughs }\end{array}$ & Classical & $\begin{array}{l}3 \\
4\end{array}$ & $\begin{array}{l}2 \\
2\end{array}$ & $\begin{array}{l}2 \\
2\end{array}$ & $\begin{array}{l}1 \\
2\end{array}$ & $\begin{array}{c}\{+19\} \\
\{+5,+7\}\end{array}$ & $\begin{array}{l}- \\
-\end{array}$ & $\begin{array}{l}1 \\
0\end{array}$ & $\begin{array}{c}\{-1\} \\
-\end{array}$ \\
\hline
\end{tabular}


Table 39:

Cyclical timing of cycles in financial variables relative to the GDP growth rate cycle

\begin{tabular}{|c|c|c|c|c|c|c|c|c|c|}
\hline \multirow[t]{3}{*}{ Financial variable } & \multirow{3}{*}{$\begin{array}{l}\text { Type of } \\
\text { cycle in } \\
\text { financial } \\
\text { variable }\end{array}$} & \multirow{3}{*}{$\begin{array}{l}\text { Number of } \\
\text { turns in } \\
\text { financial } \\
\text { variable } \\
\text { cycle }\end{array}$} & \multirow{3}{*}{$\begin{array}{l}\text { Number of } \\
\text { turns in } \\
\text { GDP } \\
\text { growth rate } \\
\text { cycle }\end{array}$} & \multirow{3}{*}{$\begin{array}{l}\text { Number of } \\
\text { turns in } \\
\text { GDP } \\
\text { growth rate } \\
\text { cycle } \\
\text { matched by } \\
\text { fin variable }\end{array}$} & \multicolumn{5}{|c|}{ Timing observations that are } \\
\hline & & & & & \multicolumn{2}{|r|}{ Leads } & \multirow{2}{*}{$\begin{array}{c}\text { Coincident } \\
\text { No. }\end{array}$} & \multicolumn{2}{|c|}{ Lags } \\
\hline & & & & & No. & Range & & No. & Range \\
\hline (1) & (2) & (3) & (4) & (5) & (6) & (7) & (8) & (9) & (10) \\
\hline $\begin{array}{l}\text { 12-month NCD rate } \\
\text { Peaks } \\
\text { Troughs }\end{array}$ & Classical & $\begin{array}{l}6 \\
5\end{array}$ & $\begin{array}{l}6 \\
6\end{array}$ & $\begin{array}{l}3 \\
5\end{array}$ & $\begin{array}{l}1 \\
3\end{array}$ & $\begin{array}{c}\{+2\} \\
\{+8 ;+1 ;+1\}\end{array}$ & - & $\begin{array}{l}2 \\
1\end{array}$ & $\begin{array}{c}\{-14 ;-3\} \\
\{-2\}\end{array}$ \\
\hline $\begin{array}{l}\text { US Federal Funds rate } \\
\text { Peaks } \\
\text { Troughs }\end{array}$ & Classical & $\begin{array}{l}3 \\
3\end{array}$ & $\begin{array}{l}6 \\
6 \\
\end{array}$ & $\begin{array}{l}3 \\
3\end{array}$ & - & $\begin{array}{c}- \\
\{+2\}\end{array}$ & - & $\begin{array}{l}3 \\
1\end{array}$ & $\begin{array}{c}\{-6 ;-1 ;-1\} \\
\{-1\}\end{array}$ \\
\hline $\begin{array}{l}\text { US 10-year govt bond yield } \\
\text { Peaks } \\
\text { Troughs }\end{array}$ & Classical & $\begin{array}{l}5 \\
5\end{array}$ & $\begin{array}{l}6 \\
6\end{array}$ & $\begin{array}{l}4 \\
4\end{array}$ & $\begin{array}{l}3 \\
2\end{array}$ & $\begin{array}{c}\{+11 ;+4 ;+5\} \\
\{+2 ;+6\}\end{array}$ & $\begin{array}{l}- \\
-\end{array}$ & $\begin{array}{l}1 \\
2\end{array}$ & $\begin{array}{c}\{-4\} \\
\{-10 ;-1\}\end{array}$ \\
\hline $\begin{array}{l}\text { MSCI Emerging Mrkt Share } \\
\text { Peaks } \\
\text { Troughs }\end{array}$ & Classical & $\begin{array}{l}4 \\
4\end{array}$ & $\begin{array}{l}5 \\
6 \\
\end{array}$ & $\begin{array}{l}2 \\
2\end{array}$ & $\begin{array}{l}1 \\
2\end{array}$ & $\begin{array}{c}\{+3\} \\
\{+4 ;+3\}\end{array}$ & $\begin{array}{l}- \\
-\end{array}$ & $\begin{array}{l}1 \\
-\end{array}$ & $\begin{array}{c}\{-7\} \\
-\end{array}$ \\
\hline $\begin{array}{l}\text { JP Morgan Emerg Mrkt Bond } \\
\text { Peaks } \\
\text { Troughs }\end{array}$ & Gr. rate & $\begin{array}{l}6 \\
5 \\
\end{array}$ & $\begin{array}{l}6 \\
6 \\
\end{array}$ & $\begin{array}{l}4 \\
5 \\
\end{array}$ & $\begin{array}{l}1 \\
2\end{array}$ & $\begin{array}{c}\{+9\} \\
\{+4 ;+3\}\end{array}$ & $\begin{array}{l}1 \\
-\end{array}$ & $\begin{array}{l}2 \\
3\end{array}$ & $\begin{array}{c}\{-2 ;-7\} \\
\{-1 ;-4 ;-6\}\end{array}$ \\
\hline
\end{tabular}


Table 40:

Cyclical timing of cycles in financial variables relative to the industrial production classical cycle

\begin{tabular}{|c|c|c|c|c|c|c|c|c|c|}
\hline \multirow{3}{*}{ Financial variable } & \multirow{3}{*}{$\begin{array}{l}\text { Type of } \\
\text { cycle in } \\
\text { financial } \\
\text { variable }\end{array}$} & \multirow{3}{*}{$\begin{array}{l}\text { No of turns } \\
\text { in financial } \\
\text { variable } \\
\text { cycle }\end{array}$} & \multirow{3}{*}{$\begin{array}{l}\text { No of turns } \\
\text { in industrial } \\
\text { production } \\
\text { classical } \\
\text { cycle }\end{array}$} & \multirow{3}{*}{$\begin{array}{l}\text { No of turns } \\
\text { in industrial } \\
\text { production } \\
\text { classical } \\
\text { cycle } \\
\text { matched by } \\
\text { fin variables }\end{array}$} & \multicolumn{5}{|c|}{ Timing observations that are } \\
\hline & & & & & \multicolumn{2}{|r|}{ Leads } & \multirow{2}{*}{$\begin{array}{c}\text { Coincident } \\
\text { No. }\end{array}$} & \multicolumn{2}{|c|}{ Lags } \\
\hline & & & & & No. & Range & & No. & Range \\
\hline (1) & (2) & (3) & (4) & (5) & (6) & (7) & (8) & (9) & (10) \\
\hline Real M3 & Classical & & & & & & & & \\
\hline Peaks & & 4 & 5 & 3 & - & - & 1 & 2 & $\{-12 ;-14\}$ \\
\hline Troughs & & 5 & 5 & 4 & 1 & $\{+5\}$ & - & 3 & $\{-3 ;-11 ;-2\}$ \\
\hline & Gr. rate & & & & & & & & \\
\hline Peaks & & 4 & 5 & 3 & 2 & $\{+3 ;+4\}$ & - & 1 & $\{-4\}$ \\
\hline Troughs & & 5 & 5 & 4 & 3 & $\{+3 ;+3 ;+2\}$ & - & 1 & $\{-2\}$ \\
\hline JSE Resources Index & Classical & & & & & & & & \\
\hline Peaks & & 5 & 5 & 3 & 2 & $\{+11 ;+1\}$ & - & 1 & $\{-16\}$ \\
\hline Troughs & & 5 & 5 & 3 & 2 & $\{+11 ;+1\}$ & - & 1 & $\{-3\}$ \\
\hline US Federal Funds rate & Classical & & & & & & & & \\
\hline Peaks & & 3 & 5 & 2 & 1 & $\{+1\}$ & - & 1 & $\{-2\}$ \\
\hline Troughs & & 4 & 5 & 3 & - & - & - & 3 & $\{-4 ;-1 ;-5\}$ \\
\hline US 10-year govt bond yield & Classical & & & & & & & & \\
\hline Peaks & & 5 & 5 & 3 & 2 & $\{+15 ;+5\}$ & 1 & - & - \\
\hline Troughs & & 5 & 5 & 5 & 2 & $\{+4 ;+2\}$ & - & 3 & $\{-14 ;-2 ;-1\}$ \\
\hline Real Effective Rand & Gr. rate & & & & & & & & \\
\hline Peaks & & 6 & $3 t$ & 4 & 1 & $\{+10\}$ & - & 3 & $\{-2 ;-7 ;-3\}$ \\
\hline Troughs & & 5 & $4 \mathrm{p}$ & 3 & 3 & $\{+2 ;+4 ;+4\}$ & - & - & - \\
\hline Real R/\$ & Gr. rate & & & & & & & & \\
\hline Peaks & & 7 & 5 & 4 & 4 & $\{+3 ;+2 ;+4 ;+5\}$ & - & - & - \\
\hline Troughs & & 7 & 5 & 3 & 2 & $\{+1 ;+2\}$ & - & 1 & $\{-1\}$ \\
\hline $\mathrm{R} / \mathrm{S}$ & Gr. rate & & & & & & & & \\
\hline Peaks & & 7 & 5 & 4 & 3 & $\{+3 ;+3 ;+5\}$ & - & 1 & $\{-5\}$ \\
\hline Troughs & & 7 & 5 & 5 & 2 & $\{+1 ;+4\}$ & - & 3 & $\{-1 ;-8 ;-5\}$ \\
\hline
\end{tabular}


Table 41:

Cyclical timing of cycles in financial variables relative to the industrial production growth rate cycle

\begin{tabular}{|c|c|c|c|c|c|c|c|c|c|}
\hline \multirow[t]{3}{*}{ Financial variable } & \multirow{3}{*}{$\begin{array}{l}\text { Type of } \\
\text { cycle in } \\
\text { financial } \\
\text { variable }\end{array}$} & \multirow{3}{*}{$\begin{array}{c}\text { No of turns } \\
\text { in financial } \\
\text { variable } \\
\text { cycle }\end{array}$} & \multirow{3}{*}{$\begin{array}{l}\text { No of turns } \\
\text { in } \\
\text { industrial } \\
\text { production } \\
\text { growth rate } \\
\text { cycle }\end{array}$} & \multirow{3}{*}{$\begin{array}{l}\text { No of turns } \\
\text { in } \\
\text { industrial } \\
\text { production } \\
\text { growth rate } \\
\text { cycle } \\
\text { matched by } \\
\text { fin } \\
\text { variables }\end{array}$} & \multicolumn{5}{|c|}{ Timing observations that are } \\
\hline & & & & & \multicolumn{2}{|r|}{ Leads } & \multirow{2}{*}{$\begin{array}{c}\text { Coincident } \\
\text { No. }\end{array}$} & \multicolumn{2}{|c|}{ Lags } \\
\hline & & & & & No. & Range & & No. & Range \\
\hline (1) & (2) & (3) & (4) & (5) & (6) & (7) & (8) & (9) & (10) \\
\hline $\begin{array}{l}\text { Real M1 } \\
\text { Peaks } \\
\text { Troughs }\end{array}$ & Classical & $\begin{array}{l}6 \\
7\end{array}$ & $\begin{array}{l}8 \mathrm{t} \\
8 \mathrm{p}\end{array}$ & $\begin{array}{l}5 \\
5\end{array}$ & $\begin{array}{r}1 \\
3\end{array}$ & $\begin{array}{c}\{+12\} \\
\{+7 ;+1 ;+2\}\end{array}$ & $\begin{array}{l}2 \\
-\end{array}$ & $\begin{array}{l}2 \\
2\end{array}$ & $\begin{array}{l}\{-1 ;-4\} \\
\{-4 ;-2\}\end{array}$ \\
\hline $\begin{array}{l}\text { Real 3-month Treasury bill } \\
\text { yield } \\
\text { Peaks } \\
\text { Troughs }\end{array}$ & Classical & $\begin{array}{l}6 \\
6\end{array}$ & $\begin{array}{l}8 \mathrm{t} \\
8 \mathrm{p}\end{array}$ & $\begin{array}{l}5 \\
5\end{array}$ & $\begin{array}{l}4 \\
4\end{array}$ & $\begin{array}{l}\{+2 ;+8 ;+4 ;+1\} \\
\{+4 ;+8 ;+1 ;+3\}\end{array}$ & - & $\begin{array}{l}1 \\
1\end{array}$ & $\begin{array}{l}\{-3\} \\
\{-2\}\end{array}$ \\
\hline $\begin{array}{l}\text { US Federal Funds rate } \\
\text { Peaks } \\
\text { Troughs }\end{array}$ & Classical & $\begin{array}{l}3 \\
4 \\
\end{array}$ & $\begin{array}{l}7 \\
8 \\
\end{array}$ & $\begin{array}{l}3 \\
4\end{array}$ & $\begin{array}{l}1 \\
1\end{array}$ & $\begin{array}{l}\{+1\} \\
\{+6\}\end{array}$ & $\begin{array}{l}- \\
-\end{array}$ & $\begin{array}{l}2 \\
3 \\
\end{array}$ & $\begin{array}{c}\{-7 ;-1\} \\
\{-4 ;-9 ;-5\}\end{array}$ \\
\hline $\begin{array}{l}\text { US } 10 \text {-year govt bond yield } \\
\text { Peaks } \\
\text { Troughs }\end{array}$ & Classical & $\begin{array}{l}5 \\
6 \\
\end{array}$ & $\begin{array}{l}7 \\
8 \\
\end{array}$ & $\begin{array}{l}5 \\
6 \\
\end{array}$ & $\begin{array}{l}4 \\
4\end{array}$ & $\begin{array}{c}\{+10 ;+7 ;+6 ;+5\} \\
\{+3 ;+1 ;+7 ;+1\}\end{array}$ & $\begin{array}{l}- \\
-\end{array}$ & $\begin{array}{l}1 \\
2 \\
\end{array}$ & $\begin{array}{c}\{-2\} \\
\{-6 ;-1\}\end{array}$ \\
\hline $\begin{array}{l}\text { Real R/\$ } \\
\text { Peaks } \\
\text { Troughs }\end{array}$ & Gr. rate & $\begin{array}{l}7 \\
7\end{array}$ & $\begin{array}{l}8 \\
8\end{array}$ & $\begin{array}{l}6 \\
6\end{array}$ & $\begin{array}{l}2 \\
3\end{array}$ & $\begin{array}{c}\{+2 ;+5\} \\
\{+1 ;+11 ;+2\}\end{array}$ & $\begin{array}{l}1 \\
-\end{array}$ & $\begin{array}{l}3 \\
3\end{array}$ & $\begin{array}{c}\{-3 ;-4 ;-1\} \\
\{-2 ;-8 ;-10\}\end{array}$ \\
\hline
\end{tabular}


Table 47:

Lead profile of cycles in financial variables relative to the official SARB cycle

\begin{tabular}{|c|c|c|c|c|c|c|c|c|c|c|c|c|c|c|c|}
\hline \multirow{2}{*}{$\begin{array}{l}\text { Financial } \\
\text { variable }\end{array}$} & \multirow{2}{*}{$\begin{array}{l}\text { Type of } \\
\text { cycle }\end{array}$} & & \multirow{2}{*}{$\begin{array}{c}\text { Sample } \\
\text { size }\end{array}$} & \multicolumn{12}{|c|}{ Extreme cases as proportion of all possible cases $(q)$, for leads of at least (months) } \\
\hline & & & & 1 & 2 & 3 & 4 & 5 & 6 & 7 & 8 & 9 & 10 & 11 & 12 \\
\hline Real M3 & Classical & $\mathrm{T}$ & 3 & 0.87 & 1.00 & 1.00 & 1.00 & 1.00 & 1.00 & 1.00 & 1.00 & 1.00 & 1.00 & 1.00 & 1.00 \\
\hline 3-m Treasury bill yield & Classical & $\mathrm{T}$ & 3 & 1.00 & 1.00 & 1.00 & 1.00 & 1.00 & 1.00 & 1.00 & 1.00 & 1.00 & 1.00 & 1.00 & 1.00 \\
\hline
\end{tabular}

Table 48:

Lead profile of cycles in financial variables relative to the GDP growth rate cycle

\begin{tabular}{|c|c|c|c|c|c|c|c|c|c|c|c|c|c|c|c|}
\hline \multirow{2}{*}{$\begin{array}{l}\text { Financial } \\
\text { variable }\end{array}$} & \multirow{2}{*}{$\begin{array}{l}\text { Type of } \\
\text { cycle }\end{array}$} & & \multirow{2}{*}{$\begin{array}{l}\text { Sample } \\
\text { size }\end{array}$} & \multicolumn{12}{|c|}{ Extreme cases as proportion of all possible cases $(q)$, for leads of at least (months) } \\
\hline & & & & 1 & 2 & 3 & 4 & 5 & 6 & 7 & 8 & 9 & 10 & 11 & 12 \\
\hline US Federal Funds rate & Classical & $\mathrm{P}$ & 3 & 1.00 & 1.00 & 1.00 & 1.00 & 1.00 & 1.00 & 1.00 & 1.00 & 1.00 & 1.00 & 1.00 & 1.00 \\
\hline \multirow{2}{*}{$\begin{array}{l}\text { JPM Emerging Market } \\
\text { Bond Index }\end{array}$} & \multirow[t]{2}{*}{ Growth rate } & $\mathrm{P}$ & 3 & 0.75 & 0.75 & 0.75 & 1.00 & 1.00 & 1.00 & 1.00 & 1.00 & 1.00 & 1.00 & 1.00 & 1.00 \\
\hline & & $\mathrm{T}$ & 5 & 0.84 & 0.91 & 0.94 & 1.00 & 1.00 & 1.00 & 1.00 & 1.00 & 1.00 & 1.00 & 1.00 & 1.00 \\
\hline
\end{tabular}


Table 49:

Lead profile of cycles in financial variables relative to the industrial production classical cycle

\begin{tabular}{|c|c|c|c|c|c|c|c|c|c|c|c|c|c|c|c|}
\hline \multirow{2}{*}{$\begin{array}{l}\text { Financial } \\
\text { variable }\end{array}$} & \multirow{2}{*}{$\begin{array}{l}\text { Type of } \\
\text { cycle }\end{array}$} & & \multirow{2}{*}{$\begin{array}{c}\text { Sample } \\
\text { size }\end{array}$} & \multicolumn{12}{|c|}{ Extreme cases as proportion of all possible cases $(q)$, for leads of at least (months) } \\
\hline & & & & 1 & 2 & 3 & 4 & 5 & 6 & 7 & 8 & 9 & 10 & 11 & 12 \\
\hline Real M3 & Classical & $\mathrm{T}$ & 4 & 0.87 & 0.94 & 0.94 & 0.94 & 1.00 & 1.00 & 1.00 & 1.00 & 1.00 & 1.00 & 1.00 & 1.00 \\
\hline Real M3 & Growth rate & $\mathrm{T}$ & 4 & 0.44 & 0.62 & 1.00 & 1.00 & 1.00 & 1.00 & 1.00 & 1.00 & 1.00 & 1.00 & 1.00 & 1.00 \\
\hline JSE Resources Index & Classical & $\mathrm{T}$ & 3 & 0.50 & 0.50 & 0.62 & 0.75 & 0.75 & 0.87 & 1.00 & 1.00 & 1.00 & 1.00 & 1.00 & 1.00 \\
\hline US 10-yr govt bond yield & Classical & $\mathrm{T}$ & 5 & 0.87 & 0.94 & 0.97 & 1.00 & 1.00 & 1.00 & 1.00 & 1.00 & 1.00 & 1.00 & 1.00 & 1.00 \\
\hline Real Effective Rand & Growth rate & $\mathrm{P}$ & 4 & 0.69 & 0.81 & 0.81 & 0.94 & 0.94 & 0.94 & 0.94 & 0.94 & 0.94 & 1.00 & 1.00 & 1.00 \\
\hline \multirow[t]{2}{*}{ Real R/\$ Exchange Rate } & \multirow[t]{2}{*}{ Growth rate } & $\mathrm{P}$ & 4 & 0.00 & 0.12 & 0.37 & 0.87 & 1.00 & 1.00 & 1.00 & 1.00 & 1.00 & 1.00 & 1.00 & 1.00 \\
\hline & & $\mathrm{T}$ & 3 & 0.75 & 0.87 & 0.87 & 0.87 & 1.00 & 1.00 & 1.00 & 1.00 & 1.00 & 1.00 & 1.00 & 1.00 \\
\hline \multirow[t]{2}{*}{$\begin{array}{l}\text { Nominal R/\$ Exchange } \\
\text { Rate }\end{array}$} & \multirow[t]{2}{*}{ Growth rate } & $\mathrm{P}$ & 4 & 0.50 & 0.56 & 0.75 & 0.94 & 1.00 & 1.00 & 1.00 & 1.00 & 1.00 & 1.00 & 1.00 & 1.00 \\
\hline & & $\mathrm{T}$ & 5 & 0.87 & 0.94 & 0.97 & 1.00 & 1.00 & 1.00 & 1.00 & 1.00 & 1.00 & 1.00 & 1.00 & 1.00 \\
\hline
\end{tabular}


Table 50:

Lead profile of cycles in financial variables relative to the industrial production growth rate cycle

\begin{tabular}{|c|c|c|c|c|c|c|c|c|c|c|c|c|c|c|c|}
\hline \multirow{2}{*}{$\begin{array}{l}\text { Financial } \\
\text { variable }\end{array}$} & \multirow{2}{*}{$\begin{array}{l}\text { Type of } \\
\text { cycle }\end{array}$} & & \multirow{2}{*}{$\begin{array}{c}\text { Sample } \\
\text { size }\end{array}$} & \multicolumn{12}{|c|}{ Extreme cases as proportion of all possible cases $(q)$, for leads of at least (months) } \\
\hline & & & & 1 & 2 & 3 & 4 & 5 & 6 & 7 & 8 & 9 & 10 & 11 & 12 \\
\hline Real M1 & Classical & $\mathrm{P}$ & 3 & 0.50 & 0.50 & 0.62 & 0.75 & 0.75 & 1.00 & 1.00 & 1.00 & 1.00 & 1.00 & 1.00 & 1.00 \\
\hline \multirow{2}{*}{ 3-m T-bill yield (real) } & \multirow{2}{*}{ Classical } & $\mathrm{P}$ & 5 & 0.37 & 0.53 & 0.75 & 0.84 & 0.94 & 0.97 & 0.97 & 1.00 & 1.00 & 1.00 & 1.00 & 1.00 \\
\hline & & $\mathrm{T}$ & 5 & 0.31 & 0.41 & 0.69 & 0.84 & 0.94 & 0.97 & 0.97 & 1.00 & 1.00 & 1.00 & 1.00 & 1.00 \\
\hline \multirow[t]{2}{*}{ US Federal Funds rate } & \multirow[t]{2}{*}{ Classical } & $\mathrm{P}$ & 3 & 0.87 & 1.00 & 1.00 & 1.00 & 1.00 & 1.00 & 1.00 & 1.00 & 1.00 & 1.00 & 1.00 & 1.00 \\
\hline & & $\mathrm{T}$ & 4 & 0.94 & 0.94 & 0.94 & 0.94 & 0.94 & 1.00 & 1.00 & 1.00 & 1.00 & 1.00 & 1.00 & 1.00 \\
\hline US 10-yr govt bond yield & Classical & $\mathrm{P}$ & 5 & 0.06 & 0.19 & 0.22 & 0.34 & 0.59 & 0.72 & 0.84 & 0.94 & 0.97 & 1.00 & 1.00 & 1.00 \\
\hline \multirow[t]{2}{*}{ Real R/\$ Exchange Rate } & \multirow[t]{2}{*}{ Growth rate } & $\mathrm{P}$ & 5 & 0.84 & 0.94 & 0.94 & 0.97 & 1.00 & 1.00 & 1.00 & 1.00 & 1.00 & 1.00 & 1.00 & 1.00 \\
\hline & & $\mathrm{T}$ & 6 & 0.78 & 0.87 & 0.89 & 0.92 & 0.95 & 0.97 & 0.98 & 0.98 & 0.98 & 0.98 & 1.00 & 1.00 \\
\hline
\end{tabular}




\section{REFERENCES}

Achuthan, L. and Banerji, A. (2004): Beating the business cycle. New York: Currency Doubleday.

Andreou, E., Osborn, D.R. and Sensier, M. (2000): A comparison of the statistical properties of financial variables in the USA, UK and Germany over the business cycle. The Manchester School 68(4): 396-418.

Aron, J. and Muellbauer, J. (2002): Estimating monetary policy rules for South Africa. Central Bank of Chile Working Paper 89. [Online]. Available: http://www.bcentral.cl/esp/estpub/estudios/dtbc/pdf/dtbc89.pdf

Artis, M., Marcellino, M. and Proietti, T. (2004): Dating business cycles: a methodological contribution with an application to the Euro area. Oxford Bulletin of Economics and Statistics 66(4): 537-565.

Artis, M., Marcellino, M. and Proietti, T. (2005): Dating the Euro area business cycle. In L. Reichlin (ed.), The Euro area business cycle: stylised facts and measurement issues. London: Centre for Economic Policy Research: 7-33.

Auerbach, A. J. (1982): The index of leading indicators: 'measurement without theory', thirty-five years later. Review of Economics and Statistics November 1982: 584-595.

Avouyi-Dovi, S. and Matheron, J., (2005): Interactions between business cycles, stock market cycles and interest rates: stylized facts. Banque de France Working Paper No 121. [Online].

Available: http://www.banque-france.fr/gb/publications/ner/1-121.htm

Banerji, A. (1999): The lead profile and other non-parametric tools to evaluate survey series as leading indicators. Paper presented at the $24^{\text {th }}$ CIRET conference held in Wellington, New Zealand from 17-20 March 1999. 
Banerji, A. (1999): The three Ps: simple tools for monitoring economic cycles. Business Economics October 1999: 72-76.

Bekaert, G. and Harvey, C.R. (2000): Foreign speculators and emerging equity markets. Journal of Finance 55: 565-614.

Bernstein, P.L. (1998): Against the gods: the remarkable story of risk. New York: John Wiley \& Sons.

Blake, D. (2003): Financial market analysis. $2^{\text {nd }}$ edition. London: John Wiley \& Sons.

Blanchard, O.J. and Fischer, S. (1989): Lectures on Macroeconomics. Cambridge, Mass.: MIT Press.

Burns, A.F. and Mitchell, W.C. (1938): Statistical indicators of cyclical revivals. National Bureau of Economic Research Bulletin 69: 1-12.

Burns, A.F. and Mitchell, W.C. (1946): Measuring business cycles. New York: National Bureau of Economic Research.

Bry, G. and Boschan, C. (1971): Cyclical Analysis of Time Series. New York: National Bureau of Economic Research.

Canova, F. (1998): De-trending and business cycle facts. Journal of Monetary Economics 41: 475-512.

Chauvet, M. and Hamilton, J.D. (2005): Dating business cycle turning points. National Bureau of Economic Research Working Paper 11422. [Online]. Available: http://www.nber.org/papers/w11422.

Chauvet, M. and Potter, S. (2005): Forecasting recessions using the yield curve. Journal of Forecasting 24: 77-103. 
Christiano, L.J. and Todd, R.M. (2002): The conventional treatment of seasonality in business cycle analysis: does it create distortions? Journal of Monetary Economics 49: 335-364.

Clements, M.P. and Hendry, D.F. (1999): Forecasting non-stationary economic time series. Cambridge, Mass.: MIT Press.

Cochrane, J.H. (2005): Financial markets and the real economy. National Bureau of Economic Research Working Paper 11193. [Online]. Available: http://www.nber.org/papers/w11193.

Conference Board. (2004): Business Cycle Indicators Vol 2 (February) No 3. New York.

Del Negro, M. (2001): Turn, turn, turn: predicting turning points in economic activity. Economic Review $2^{\text {nd }}$ Quarter 2001. Federal Reserve Bank of Atlanta.

Diebold, F.X. and Rudebusch, G.D. (1999): Business cycles: durations, dynamics, and forecasting. $1^{\text {st }}$ edition. Princeton: Princeton University Press.

Dudley, W. and Hatzius, J. (2000): The Goldman Sachs Financial Conditions Index: the right tool for a new monetary policy regime. Goldman Sachs Global Economics Paper No. 44. [Online]. Available: www.ic.sunysb.edu/Class/eco357/GoldmanSachs\%20FinCondIndex.pdf

Du Plessis, S.A. (2004): Reconsidering the business cycle and stabilisation policies in South Africa. Paper presented at the eight annual Conference for Econometric Modelling in Africa.

Du Plessis, S.A. (2005): Business cycles in emerging market economies: a new view of the stylised facts. Paper presented at the 2005 Conference of the Economic Society of South Africa held from 7-9 September in Durban. 
Edwards, S., Gómez Biscarri, J. and Pérez De Gracia, F. (2003): Stock Market Cycles, Financial Liberalization and Volatility. National Bureau of Economic Research Working Paper No. 98/17. [Online]. Available: http://www.nber.org/w9817

Estrella, A. and Mishkin, F.S. (1998): Predicting US recessions: financial variables as leading indicators. The Review of Economics and Statistics 80: 45-61.

Filardo, A.J. (1999): How reliable are recession prediction models? Federal Reserve Bank of Kansas City Economic Review 83 (Second Quarter): 35-55.

Fisher, R.A. (1935): The design of experiments. Edinburgh: Oliver \& Boyd.

Friedman, M. and Schwartz, A. (1963): A Monetary History of the United States, 1867 - 1960. Princeton: Princeton University Press.

Gómez Biscarri, J. and Pérez de Gracia, F., (2003): Stock market cycles and stock market development in Spain. Working Paper No 01/02, University of Navarre.

Granger, C.W.J. (1989): Forecasting in business and economics. $2^{\text {nd }}$ edition. San Diego: Academic Press.

Granger, C.W.J. (2003): Time series analysis, cointegration, and applications. Nobel Lecture on 8 December 2003.

Harding, D. and Pagan, A. (2001): Extracting, analysing and using cyclical information. Melbourne: Melbourne Institute of Applied Economics and Social Research.

Harding, D. and Pagan, A. (2002): Dissecting the cycle: a methodological investigation. Journal of Monetary Economics 49: 365-381.

Harding, D. and Pagan, A. (2003): Synchronisation of cycles. Melbourne: Melbourne Institute of Applied Economics and Social Research. 
Harding, D. and Pagan, A. (2005): A suggested framework for classifying the modes of cycle research. Journal of Applied Econometrics 20(2): 151-159.

Hayashi, F. (2004): Econometrics. $1^{\text {st }}$ edition. Princeton: Princeton University Press.

Jagric, T. and Strasek, S. (2005): A nonlinear extension of the NBER model for shortrun forecasting of business cycles. South African Journal of Economics 73(3): 435-448.

Kahn, B. and Farrell, G.N. (2002): South African real interest rates in comparative perspective: theory and evidence. South African Reserve Bank Occasional Paper No 17. [Online]. Available: http://www.reservebank.co.za

Kaminsky, G.L. and Schmukler, S.L. (2003): Short-run pain, long-run gain: the effects of financial liberalization. National Bureau of Economic Research Working Paper No. 9787. [Online]. Available: http://papers.nber.org/papers/w9787.pdf

Koopmans, T.C. (1947): Measurement without theory. Review of Economic Statistics 29(3): 161-172.

McDermott, C.J. and Scott, A. (2000): Concordance in business cycles. National Bureau of Economic Research Working Paper No. 00/37. [Online]. Available: http://www.nber.org/w0037

Mohr, P. (2000): Economic Indicators. Pretoria: Unisa Press.

Moolman, E. (2003): Predicting turning points in the South African economy. South African Journal of Economic and Management Sciences 6(2): 289-303.

Moolman, E. and Jordaan, J. (2005): Can leading business cycle indicators predict the direction of the South African commercial share price index? South African Journal of Economics 73(1): 68-78. 
Moore, G.H. (1950): Statistical indicators of cyclical revivals and recessions. National Bureau of Economic Research Occasional Paper 31. New York: National Bureau of Economic Research.

Muellbauer, J. and Nunziata, L. (2004): Forecasting (and explaining) U.S. business cycles. Paper presented at a seminar in July 2004 at the University of Stellenbosch.

Neftci, S.N. (1982): Optimal prediction of cyclical downturns. Journal of Economic Dynamics and Control 4 (November): 225-241.

Newey, W.K. and West, K.D. (1987): A simple, positive semi-definite, heteroscedasticity and autocorrelation consistent covariance matrix. Econometrica 55: 703-708.

OECD (2005): Leading Indicators Webpage. [Online]. Available: http://www.oecd.org/std

Osborn, D.R., Sensier, M. and Van Dijk, D. (2005): Predicting growth regimes for European countries. In L. Reichlin (ed.), The Euro area business cycle: stylised facts and measurement issues. London: Centre for Economic Policy Research: 61-77.

Pagan, A.R. (2003): Reflections on some aspects of macro-econometric modelling. Lecture to the African Econometrics Conference, Stellenbosch 2003.

Pagan, A.R. (2004): Lecture 2: Measuring the cycle. Lecture to IMF staff on 16 August 2004. New York: IMF.

Pagan, A.R and Sossounov, K.A. (2003): A simple framework for analysing bull and bear markets. Journal of Applied Econometrics 18: 23-46.

Pretorius, W.S. and Venter, J.C. (2004): Note on the revision of composite leading and coincident business cycle indicators. SARB Quarterly Bulletin March: 67-72. 
Sarantis, N. and Lin, S.X. (1999): The role of financial spreads in macroeconomic forecasting: evidence from the UK. The Manchester School 67(1): 89-110.

Siegel, S. (1956): Nonparametric statistics for the behavioural sciences. $1^{\text {st }}$ edition. New York: McGraw-Hill.

South African Reserve Bank (2005): Quarterly Bulletin September 2005. Pretoria: South African Reserve Bank.

Stock, J.H. and Watson, M.W. (2003): Forecasting output and inflation: the role of asset prices. Journal of Economic Literature XLI (September 2003): 788-829.

R Foundation for Statistical Computing (2005): A Language and Environment for Statistical Computing. Vienna: ISBN 3-9000051-00-3. [Online]. Available: http://www.R-project.org

Romer, C.D. and Romer, D.H. (1994): What ends recessions? National Bureau of Economic Research Working Paper 4765. [Online]. Available: http://www.nber.org/papers/w4765.

Van Coller, J.E.M. (1980): A system of composite leading and coinciding indices of the South African business cycle. Journal of Studies in Economics and Econometrics 8 (August): 41-73.

Van der Walt, B.E. (1983): Aanwysers van konjunktuurveranderings in Suid-Afrika. SARB Quarterly Bulletin March: 65-75.

Van Rensburg, M.P.J. (1990): A reference cycle and leading indicator for South African financial markets: some results. Unpublished MBA dissertation. Graduate School of Business, University of Stellenbosch.

Venter, J.C. and Pretorius, W.S. (2004): Note on the revision of composite leading and coincident business cycle indicators. SARB Quarterly Bulletin March: 6772. 
Venter, J.C. (2005): A brief history of business cycle analysis in South Africa. Presentation to the OECD Workshop on Composite Leading Indicators for Major OECD Non-Member Economies, 25-26 April 2005.

Venter, J.C. (2005): Reference turning points in the South African business cycle: recent developments. SARB Quarterly Bulletin September: 61-70. 